\title{
Interstitial Annelida
}

\author{
Katrine Worsaae ${ }^{1, *} \oplus$, Alexandra Kerbl ${ }^{1,2} \oplus$, Maikon Di Domenico ${ }^{1,3} \oplus$, Brett C. Gonzalez ${ }^{1,4}$, \\ Nicolas Bekkouche ${ }^{1,5}$ (D) and Alejandro Martínez ${ }^{1,6}$ (i)
}

1 Marine Biological Section, Department of Biology, University of Copenhagen, Universitetsparken 4, 2100 Copenhagen, Denmark; alexandra.kerbl@uni-hamburg.de (A.K.); maik2dd@gmail.com (M.D.D.); gonzalezb@si.edu (B.C.G.); nicolas.bekkouche@gmail.com (N.B.); alejandro.martinezgarcia@cnr.it (A.M.)

2 Center of Natural History-Zoological Museum, Universität Hamburg, Martin-Luther-King-Platz 3, 20146 Hamburg, Germany

3 Center for Marine Studies, Federal University of Paraná, Av. Beira Mar s/n, 83255-976, Pontal do Sul, Pontal do Paraná, Paraná 83255-976, Brazil

4 Smithsonian Institution, National Museum of Natural History, Department of Invertebrate Zoology, P.O. Box 37021, Washington, DC 20013-7012, USA

5 Institut de Systématique, Evolution, Biodiversité, ISYEB-UMR 7205 MNHN CNRS UPMC EPHE, Sorbonne Universités, 45 rue Buffon, 75005 Paris, France

6 Molecular Ecology Group (MEG), Water Research Institute (IRSA), National Research Council of Italy (CNR), 28922 Verbania, Italy

* Correspondence: kworsaae@bio.ku.dk

Citation: Worsaae, K.; Kerbl, A.; Domenico, M.D.; Gonzalez, B.C.; Bekkouche, N.; Martínez, A. Interstitial Annelida. Diversity 2021 13, 77. https://doi.org/10.3390/ d13020077

Academic Editors: Michael Wink, Maria Capa and Pat Hutchings

Received: 22 December 2020

Accepted: 2 February 2021

Published: 12 February 2021

Publisher's Note: MDPI stays neutral with regard to jurisdictional claims in published maps and institutional affiliations.

Copyright: (c) 2021 by the authors. Licensee MDPI, Basel, Switzerland This article is an open access article distributed under the terms and conditions of the Creative Commons Attribution (CC BY) license (https:// creativecommons.org/licenses/by/ $4.0 /)$

\begin{abstract}
Members of the following marine annelid families are found almost exclusively in the interstitial environment and are highly adapted to move between sand grains, relying mostly on ciliary locomotion: Apharyngtidae n. fam., Dinophilidae, Diurodrilidae, Nerillidae, Lobatocerebridae, Parergodrilidae, Polygordiidae, Protodrilidae, Protodriloididae, Psammodrilidae and Saccocirridae. This article provides a review of the evolution, systematics, and diversity of these families, with the exception of Parergodrilidae, which was detailed in the review of Orbiniida by Meca, Zhadan, and Struck within this Special Issue. While several of the discussed families have previously only been known by a few described species, recent surveys inclusive of molecular approaches have increased the number of species, showing that all of the aforementioned families exhibit a high degree of cryptic diversity shadowed by a limited number of recognizable morphological traits. This is a challenge for studies of the evolution, taxonomy, and diversity of interstitial families as well as for their identification and incorporation into ecological surveys. By compiling a comprehensive and updated review on these interstitial families, we hope to promote new studies on their intriguing evolutionary histories, adapted life forms and high and hidden diversity.
\end{abstract}

Keywords: systematics; identification; meiobenthos; annelids

\section{Introduction}

"To see the world in a grain of sand ..." (William Blake) reaches another meaning when it comes to the amazing diversity of animals revealed upon examining a handful of sand. Interstices between sand grains constitute a generally protected and well-oxygenated environment, rich in trapped organic matter and benthic microalgae [1]. This environment houses a great diversity of microscopic metazoans [2], particularly among harpacticoid copepods and the worm-like taxa Nematoda, Acoela, Gnathostomulida, Gastrotricha, Platyhelminthes, and Annelida. Within Annelida, interstitial forms have evolved a significantly high number of times from larger ancestors, resulting in more than 400 species that are distributed across 14 macrofaunal families and 13 interstitial families [3,4]. Whereas the two meiofaunal freshwater families Aeolosomatidae Levinsen, 1884 and Potamodrilidae Bunke, 1967 are found in various environments, the following 11 marine families are exclusively interstitial: Apharyngtidae n. fam., Dinophilidae Macalister, 1876, Diurodrilidae Kristensen and Niilonen, 1982, Lobatocerebridae Rieger, 1980, Nerillidae Levinsen, 1883, 
Parergodrilidae Reisinger, 1925, Polygordiidae Czerniavsky, 1881, Protodrilidae Hatschek, 1888, Protodriloididae Purschke and Jouin, 1988, Psammodrilidae Swedmark, 1952 and Saccocirridae Bobretzky, 1872.

Many interstitial species are considered meiofaunal, a term that today is generally applied to species that pass through a $500 \mu \mathrm{m}$ mesh size but are retained on a $42 \mu \mathrm{m}$ mesh [1]. This definition implies that not all meiofaunal species are microscopic, since a long "meiofaunal" species might be able to squeeze itself through a $500 \mu \mathrm{m}$ mesh. The term "interstitial" allows for a broader size range, just referring to animals capable of moving through the interstices without displacing the sediment particles. As a result, there are evident differences in size between interstitial annelids, e.g., from the minute Diurodrilus minimus Remane, 1925, (ca. 250-450 $\mu \mathrm{m}$ long) to the comparatively enormous Saccocirrus major Pierantoni, 1907 (up to $70 \mathrm{~mm}$ long). Moreover, a few of the largest "interstitial" annelids may actually perform muscular burrowing, displacing the sand grains, rather than gliding in between them. Acknowledging these inconsistencies, we use the term interstitial, which best fits the majority of annelids addressed in this article. Indeed, most of these families share a common set of adaptations to the interstitial environment, such as ventral motile ciliation (for gliding), adhesive glands, and small and/or slender bodies. Historically, the marine families Dinophilidae, Histriobdellidae (not interstitial), Nerillidae, Polygordiidae, Protodrilidae, and Saccocirridae (but not Parergodrilidae and Psammodrilidae) were regarded as part of the now abandoned group "Archiannelida" [5]. The concept of Archiannelida originated from Hatschek's studies on Polygordius [6], possessing a superficially simple adult morphology but a highly advanced trochophore-like larva from which, he concluded, all other annelids with a trochophore larva might have derived. Nowadays, the archiannelid concept has been abandoned and all the interstitial marine families have been shown to be secondarily small, generally unrelated, highly derived lineages [7-13]. Nonetheless, the exact phylogenetic positions of many of these families remain debated, even after the analysis of large transcriptomic datasets, e.g., [8-13], and extensive morphological revisions based on state-of-the-art microscopy and imagining technology, e.g., [9,14-22]. Despite these challenges and incongruences, we summarize the phylogenetic positions of the eleven marine interstitial families based on the most recent phylogenomic analyses (Figure 1), while specific problems and alternative placements are further discussed in the subchapter of each family. Nonetheless, Figure 1 illustrates that the marine interstitial families represent at least five independent lineages: (1) Psammodrilidae is nested in a group of macrofaunal annelids, next to Apistobranchidae [9]. (2) Dinophilidae and Lobatocerebridae were recently proposed to constitute a clade called Dinophiliformia, sister to Pleistoannelida [12], but see also [10,11]. (3) Protodrilidae, Saccocirridae, and Protodriloidae form a well-supported clade within Errantia in all phylogenomic analyses, e.g., [11], sometimes recovered next to Polygordiidae. (4) Nerillidae has been recovered nested among either errantian, e.g., [13], or sedentarian taxa [11], sometimes closely related to other interstitial families [11]. (5) Diurodrilidae and Apharyngtidae n. fam. group together within the larger sedentarian clade Orbiniida, which also contains Parergodrilidae, e.g., $[11,12]$.

Perhaps correlated with this phylogenetic and morphological disparity, these interstitial families show a wide range of ecological preferences. Individuals of some genera have never been found outside of the interstitial environment and show notable pharyngeal, glandular, and ciliary specializations (e.g., Trilobodrilus Remane, 1925; Psammodrilidae; Lobatocerebrum Rieger, 1980; Diurodrilidae; and Protodriloididae). Some of these species colonize the phreatic coastal waters through the upper beach zone (e.g., in Diurodrilidae), protected from waves and currents, and have secondarily lost some of their adhesive structural adaptations found in their close relatives [23-25]. Other species (e.g., in Dinophilidae and Nerillidae) are epibenthic, grazing on biofilms growing on sediments, gravel, and seaweeds e.g., [26,27]. 


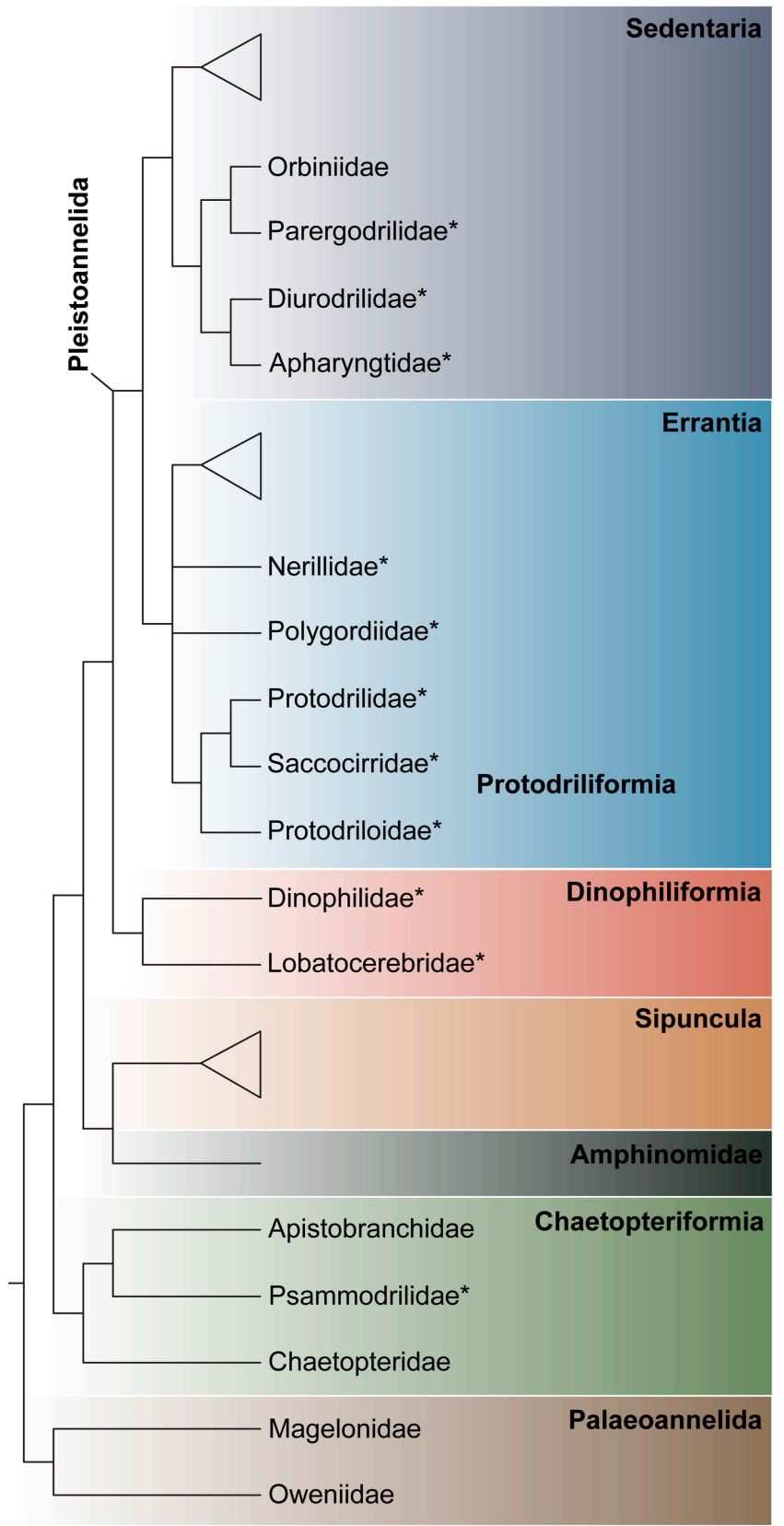

Figure 1. Selected hypotheses on the evolutionary relationship of interstitial annelid families $\left({ }^{*}\right)$, summarizing some of the most recent phylogenomic analyses [3,7-9]. Problems and alternatives to the depicted positions are discussed in the subchapter of each family (e.g., Nerillidae has been suggested to nest both with Errantian and Sedentarian taxa). Branches ending as a triangle indicate a cluster of multiple families.

Large species of Polygordiidae and Protodrilidae prefer the flocculent organic matter accumulated on top of the sediment, whereas the so-called surfing-species of Saccocirrus, Protodrilus, and Megadrilus drift along with the waves in the highly energetic zones of sandy beaches [28,29]. Some protodrilids are even semi-sessile suspension feeders [28,30], while the aberrant Astomus taenioides Jouin, 1979 lacks a functional mouth and gut, taking up nutrients through its body wall [31]. However, the highest ecological ubiquity is found amongst Nerillidae [32], the members of which are specialized to a wide range of habitats, such as mud e.g., [33], intertidal algae [27], groundwater [34], and anchialine caves e.g., [35-37], as well as deep-sea hydrothermal vents [38] and bacterial mats [39]. Two cave exclusive lineages of interstitial annelids, i.e., Speleonerilla Worsaae, Sterrer, and Iliffe, 
in Worsaae et al., 2018 and Megadrilus pelagicus Martínez, Kvindebjerg, Iliffe, and Worsaae, 2017, have even colonized the water columns of anchialine caves from interstitial ancestors, convergently gaining new traits to feed on suspended organic matter [40-42]. This vast range of life strategies, somewhat neglected in the literature, opens up new questions regarding early ecological radiations within these groups, emphasizing their potential as models for understanding general eco-evolutionary processes, including ecological radiations and adaptive morphological change as well as putative responses of marine organisms to future global and local climate changes [29,41,43,44].

It is difficult to make general statements on the biogeography and species diversity of interstitial annelids mostly due to two reasons; firstly, the available records for most species are fragmentary and therefore the distribution of most interstitial groups more likely reflect the unbalanced sampling effort across the world rather than any biological meaningful factors $[45,46]$; and secondly, many of these records are based on morphological identification, which largely underestimate species diversity in most of the investigated interstitial annelid lineage $[20,37,47,48]$, leading to an inflated number of "cosmopolitan" species. Many of these "cosmopolitan" species have been shown to represent species complexes and a profound hidden diversity when examined using molecular approaches or when more detailed morphological studies are performed (e.g., [49]). In that regard, it is important to consider that not only may light microscopy observations fail to distinguish species, but sometimes even detailed morphological characterization combining measurements with confocal laser and scanning electron microscopy are insufficient to identify otherwise well-defined molecular lineages (e.g., [26,37,42]). Moreover, interstitial annelids represent a polyphyletic assemblage of animals with long evolutionary histories and different phylogenetic affinities, morphological traits, and ecological preferences [3]. Therefore, it is unlikely that their current distribution patterns have been affected by comparable processes and can thus be collectively discussed. However, it may be easier to extract meaningful biogeographical patterns when focusing on specific lineages such as single genera or species complex. For example, a single species of Dinophilus has recently been documented to be distributed across the Northern Atlantic using molecular data [26], whereas individuals belonging to the Astomus taenioides Jouin, 1979 species complex are restricted to the Pacific [50], and many cave species of Mesonerilla Remane, 1949 and Speleonerilla, as well as Megadrilus pelagicus, are endemic to individual cave systems (e.g., [41,42]). Of course, these patterns might still be considered with caution, since further sampling might render them spurious. This was illustrated by species of Pharyngocirrus Di Domenico, Martínez, Lana, and Worsaae, 2014, which were believed to be restricted to the Indopacific and Western Atlantic but were recently widely recorded throughout the Mediterranean and the Eastern Atlantic [51].

The goal of this paper was to provide an update and comprehensive review of our current knowledge on the eleven families of exclusively interstitial annelids. After a section devoted towards specialized methods applied to their study, we allocate a sub-chapter to each of these families. For each of them, we provide an overview of their current systematic placement along with the diversity and most relevant morphological features used in the identification of each genera. We complete each section with a review of their ecology and distribution patterns as well as a list of the most relevant literature. In order to increase the readability of the text, a reference to taxonomic authors will be limited in the taxonomic section under each family, along with the citation to each of the papers. We hope this review will stimulate further research on these somehow neglected Annelida, not only providing crucial elements to understand their character evolution within the phylum, but also as a potentially useful model for addressing broad eco-evolutionary questions across the marine realm. 


\section{Materials and Methods}

\subsection{Extraction Methods}

One of the main challenges related to the study of interstitial annelids is that contrary to many other annelid groups, they are best investigated alive. Therefore, several extraction methods have been developed over the years in order to carefully extract the fragile animals from the substrate they live in without harming or breaking them. Methods widely used in other annelids or meiofaunal species, such as freshwater shock-treatment, harsh mixing, or formalin bulk-fixations are not recommended for interstitial annelids, as they will often destroy individuals or recover them in poor condition for subsequent morphological identification $[2,52,53]$. For the same reason, the use of density gradients, such as colloidal silica polymer (Ludox-TM) [54] or centrifugation methods, is disregarded.

Extraction of meiofauna from sandy sediments routinely involves the decantation of previously anesthetized samples through a mesh. Typically, large sediment samples must rest in the lab for a few hours or days after collection, so that the animals migrate to the uppermost two to five centimeters of the sediment. This layer is then scooped into a separate container with a 1:1 mix of sea water and isotonic $\mathrm{MgCl}_{2}$-solution (or $\mathrm{MgSO}_{4}$ ), gently stirred, and then left for 10-20 min in order to anesthetize the animals. After that time, the sediment is gently mixed again and the supernatant is decantated through a 30-100 $\mu \mathrm{m}$ mesh, often using a funnel-shaped sewn mesh, playfully referred to as a "mermaid bra" amongst meiobenthologists. This process might be repeated three to four times to ensure a total extraction of the fauna. The material retained within the "mermaid bra" is then transferred directly into petri dishes containing sea water, from which the animals are sorted out using a dissecting scope. Alternatively, the filtered material can be placed into small secondary 30-100 $\mu \mathrm{m}$ mesh sieves, which are then placed inside a petri dish with seawater. Over time, meiofaunal animals will squeeze through the mesh and accumulate in the underlying petri dish, making their sorting easier since most of the debris and larger individuals are retained in the mesh [2,52]. Once in the petri dish, animals are carefully picked up using plastic or glass Pasteur pipettes with a narrow opening. The fine tips create a rapid flux, making the animal collection more efficient.

Extraction from other substrates, such as silt, mud, and macroalgae, does not require anesthetization, since the animals in these habitats lack adhesive glands. Instead, for example, the mud sample (or the top layers of this) is resuspended in a large bucket of seawater, and left to settle for a minute or so, whereafter the surface layers are screened with a 100-200 $\mu \mathrm{m}$ aquarium net. The net is thereafter rinsed into a finer cone mesh ("mermaid bra"), transferred to a Petri dish and sorted [2]. Extraction from algae can be simply done by squeezing and rinsing a number of algae pieces, or parts of larger algae, onto a fine mesh.

\subsection{Fixation and Preservation Methods}

Preservation for DNA extraction is usually done using molecular grade ethanol (>95\%), although special buffers (i.e., RNAlater) or snap freezing in liquid nitrogen are necessary for RNA-extraction and/or give higher DNA yields, which is essential for transcriptome- or genome analyses, respectively. Preserved samples must be stored at $-20-80^{\circ} \mathrm{C}$. Samples preserved for molecular analyses are not suitable for morphological investigation, and solutions proposed to be versatile for morphological and molecular studies such as DESS (20\% DMSO, 0.25M disodium EDTA, saturated with NaCL, pH 8.0) [55] or HistoChoice Tissue Fixative (Amresco, patent \#5,429,797, Solon, OH, USA) [56] do not work well with these soft-bodied, ciliated animals.

The selection of different fixatives and reagents for morphological analyses depends on the intended use of the samples. Fixation should be done on anesthetized animals and works better if fixatives, buffers, and samples are kept at the same temperature and osmolarity. Glutaraldehyde, trialdehyde [57] or any other mixture of paraformaldehyde and glutaraldehyde (i.e., Trumps (e.g., from product nr. 18030, Electron Microscopy Sciences, Hatfield, PA, USA) [58], SPAFG (3\% glutaraldehyde, 1\% paraformaldehyde, $7.5 \%$ picric 
acid saturated solution, $0.45 \mathrm{M}$ sucorse, $70 \mathrm{mM}$ cacodylate buffer) [59]) offer the best morphological fixation and are ideal for light microscopy, histology, and electron microscopy. For aldehyde-based fixatives, results can be enhanced by postfixation with osmium tetroxide at low concentrations $(<1 \%)$. Direct fixation in $1 \%$ osmium tetroxide provides optimal fixation results for scanning electron microscopy in some groups. Since glutaraldehyde irreversibly binds proteins, fixation in $<4 \%$ paraformaldehyde is preferred in immunohistochemical studies. Sufficient preservation by simultaneous epitope accessibility requires rather short fixation times and several rinses in appropriate buffer solutions (i.e., phosphate buffered saline, PBS), followed by storage in this buffer with fungicides (e.g., $0.05 \% \mathrm{NaN}_{3}$ ). Vouchers or museum specimens should be progressively transferred into $70-75 \%$ alcohol (in sealed vials), or whole mounted in glycerine on permanent slides sealed with resin or nail polish for long term storage

\subsection{Morphological and Molecular Methods for Species Identification}

Morphological identification requires combined light and electron microscopical observations, often at high magnification. Differential interference contrast (DIC) helps when examining epidermal structures such as cilia and glands, whereas phase contrast enhances hard structures such as jaws, chaetae, stylets, and scales. Description of coloration, glandular structures or epidermal patterns, as well as some internal structures (e.g., nephridia), demands observations on live individuals. External ciliary structures (i.e., ciliary bands, ciliary tufts) are better studied using scanning electron microscopy (SEM) $[37,42,60]$, whereas internal ciliated structures such as nephridia and gonoducts are better revealed using confocal laser scanning microscopy (CLSM) and immunolabelling [42,61].

Descriptions and identification should be accompanied by molecular studies. Although next generation sequencing is getting more affordable, and protocols manage to produce good results even with a limited input of RNA or DNA, Sanger sequencing of conserved and fast evolving genes, predominantly the nuclear ribosomal markers (18S rRNA and 28S rRNA) as well as the mitochondrial markers $16 \mathrm{~S}$ rRNA, COI, and CytB, are sufficient to resolve both inter- and intraspecific relationships (e.g., [26,48,62-68]).

\section{Results}

3.1. Apharyngtidae n. fam

3.1.1. Phylogenetic Affinities

Apharyngtidae $\mathrm{n}$. fam. is a monotypic family of annelids that includes the single species Apharyngtus punicus. This species was originally described as a member of Dinophilidae based on its transverse ciliation, dorso-ventrally flattened body and the lack of appendages and chaetae [69]. Subsequently, A. punicus was transferred (along with Dinophilidae) to Dorvilleidae following the results of a morphologically based cladistic analysis [69-71] (see below). However, phylogenomic investigations [11,12] do not support a close relationship of Apharyngtus with Dorvilleidae, and only in some analyses, find them within Dinophilidae. However, a sister group relationship between Apharyngtus and Diurodrilidae within the clade Orbiniida was found in several analyses $[11,12]$. The nesting within Orbiniida suggests a progenetic origin for A. punicus, further supported by the presence of transverse ciliary bands on the prostomium and surrounding the mouth segment, resembling those found in the polytrochous larvae of Orbiniidae [11]. However, the morphological distinctiveness and newly available molecular evidence for Apharyngtus, representing a separate evolutionary lineage, highlights the need for a new family designation. Therefore, Apharyngtidae $\mathrm{n}$. fam. is herein formally established and is in line with previous findings [71].

\subsubsection{Morphology}

Since this group is only represented by one species, the morphological characteristics are treated in the taxonomy section. Apharyngtidae resembles Diurodrilidae in the small size, lack of appendages and chaetae, and by the presence of paired posterior gonopores. 


\subsubsection{Taxonomy}

Apharyngtidae $\mathrm{n}$. fam.

ZooBank Number: urn:lsid:zoobank.org:pub:018F0060-208A-44DF-9D2F-3334D736AB3A.

Diagnosis: A microscopic annelid lacking appendages and chaetae, having multiple indistinct segments (Figure 2). The prostomium, peristomium, and pygidium are well delineated by ciliary bands and epidermal constrictions. A muscular pharyngeal bulb is absent. Ventrally, three dense longitudinal bands of locomotory cilia extend along the trunk. Internally, the densely ciliated mouth opens ventrally on the peristomium, continuing into a heavily ciliated esophagus, mid- and hindgut. The anus is located dorsally on the pygidium. A minimum of three pairs of segmental protonephridia are present. Both coelom and a blood vascular system were undetected, but coelenchyme cells are scattered throughout the body. Gonochoristic and sexually monomorphic. Females carry oocytes in the posterior segments and a pair of ventral gonopores near the pygidium. Males carry filiform spermatozoa, an unpaired copulatory organ and several ciliated glandular pores near the pygidium. A larval stage seems to be lacking and direct development is assumed.

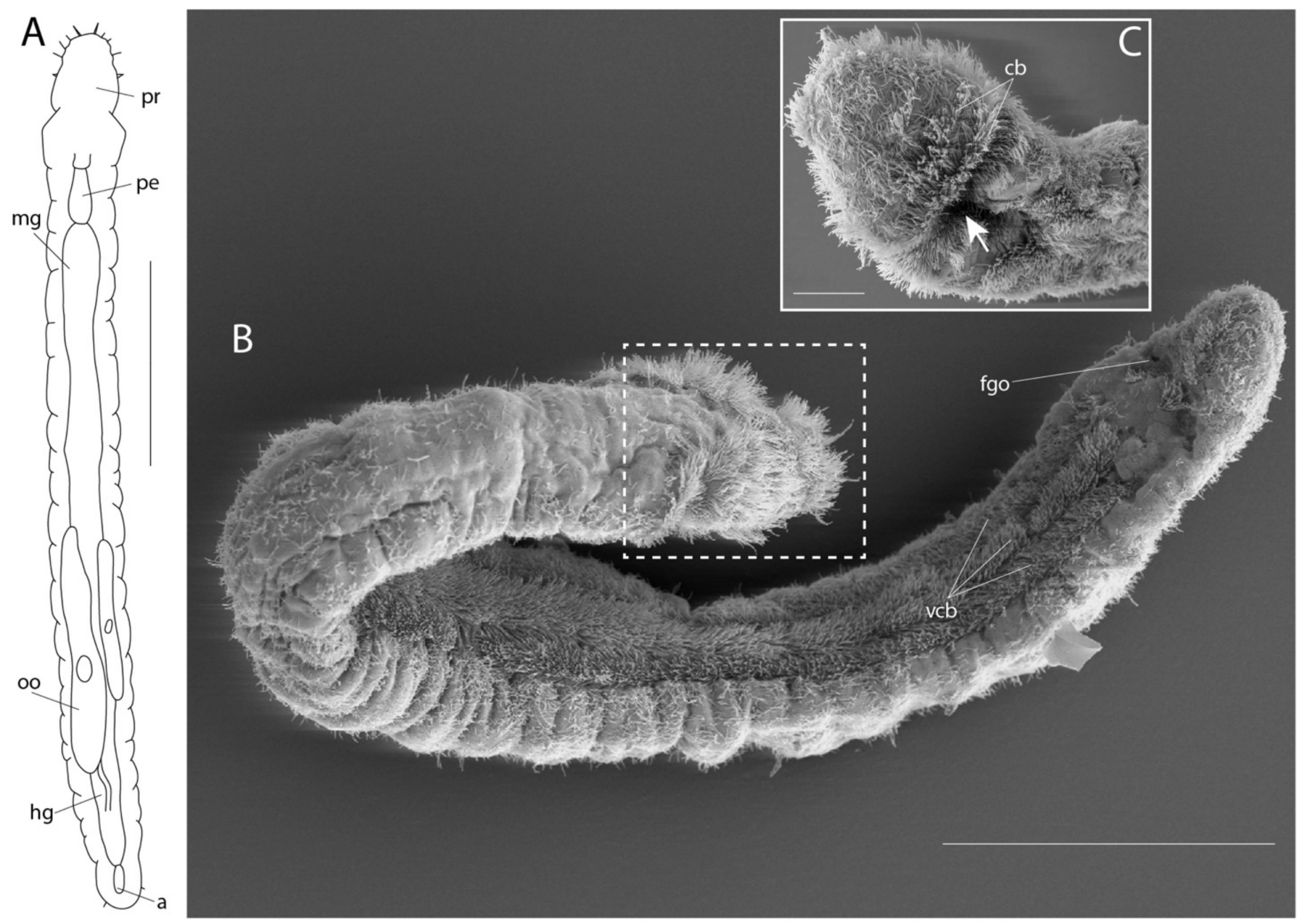

Figure 2. Apharyngtus punicus Westheide, 1971. (A) Dorsal overview of a mature female, redrawn from Westheide [72]. Scale $=200 \mu \mathrm{m} ;($ B $)$ scanning electron micrograph of a mature female in semi-curled state, note the three ventral longitudinal bands of locomotory cilia. Prostomium enclosed by the dashed box. Scale $=100 \mu \mathrm{m}$; (C) scanning electron micrograph of the ventral side of the prostomium. White arrow indicates mouth opening. Scale $=20 \mu \mathrm{m}$. Micrographs courtesy of Günter Purschke. Abbreviations: a, anus; cb, ciliary bands; fgo, female genital opening; hg, hindgut; mg, midgut; oo, oocyte; pe, posterior esophagus; pr, prostomium; vcb, ventral ciliary bands. 
Diagnosis (modified from [72]): The only described member is 610-940 $\mu \mathrm{m}$ long and less than $100 \mu \mathrm{m}$ in width. The elongated body supposedly has 18-20 externally indistinct segments. Three incomplete transverse ciliary bands are present on the prostomium, and scattered ciliation covers the trunk segments.

Monotypic. Type species: Apharyngtus punicus Westheide, 1971

\subsubsection{Distribution}

Apharyngtus punicus is likely a microphagous feeder, grazing on diatoms, bacteria, and detritus $[71,73]$. Apharyngtus was originally described in Tunisia and has been subsequently recorded in Corsica and the North Island of New Zealand [71,72,74], possibly representing undescribed species. Apharyngtus has been only found intertidally in the upper shoreline in fine sandy sediments between 5 and $15 \mathrm{~cm}$ depths $[3,71]$.

\subsubsection{Major Revisions and Most Important Literature}

The main and most recent review on the family is by Westheide (2019) [71].

\subsection{Dinophilidae Macalister, 1878}

\subsubsection{Phylogenetic Affinities}

The family Dinophilidae consists of eighteen described microscopic species, all having six trunk segments (with the exception of the dwarf males) and inhabiting biofilms, coarse sediments, or living on macroalgae [53,75]. Dinophilids were first described as Platyhelminthes before being recognized as an annelid family. Previous morphological studies suggested Dinophilidae to be the last step in a miniaturization sequence within Dorvilleidae [69], but this hypothesis was rebutted by later molecular analyses [76]. Recent phylogenomic studies recovered conflicting relationships for Dinophilidae, either unresolved [10], or forming a clade within Orbiniida, along with Nerillidae and Diurodrilidae [11], or in the latest well supported analyses as a sister group to Lobatocerebridae [12] within Dinophiliformia; a sister group to Pleistoannelida in most analyses [12]. Dinophilidae and Lobatocerebridae share morphological characters such as widely separated ventral nerve cords, an unpaired medioventral nerve and a particularly broad range of epidermal glands partly condone the otherwise stark differences in brain organization, ciliation patterns, and segmentation.

Starting with Remane's description of the genus Trilobodrilus in 1925 [77] up to the morphological and molecular revision in 2019 [26], the family was long been thought to contain only two genera, Dinophilus and Trilobodrilus. Dinophilus then included both monomorphic species with long life cycles as well as species with strong sexual dimorphism and a short life cycle [53,75]. However, a recent phylogenetic analysis [26] shows the monomorphic Dinophilus and Trilobodrilus to form a clade, sister to a clade containing the sexually dimorphic species and then named Dimorphilus (Figure 3A). Developmental studies of Trilobodrilus are warranted for comparison with the two other genera, otherwise showing highly similar morphology [78-80].

\subsubsection{Morphology}

All Dinophilidae are microscopic in size, ranging from the diminutive $50 \mu \mathrm{m}$-long dwarf males of $D$. gyrociliatus, to the approximately $3 \mathrm{~mm}$-long adult $D$. vorticoides $[26,53,75,81]$. They all have an elongated, cigar-shaped body, being plump in Dinophilus- and Dimorphilus-species, while slender in Trilobodrilus. A slight constriction demarcates the head from the six poorly delineated body segments, followed by a tapering pygidium (Figures 3B-D and 4A,D,G). Dinophilids also have a dense and broad ventral ciliary tract that is used for locomotion, and, in its anterior part, aids the transport of food particles into the Y-shaped mouth (Figures 3B-D and 4A,D,G). 


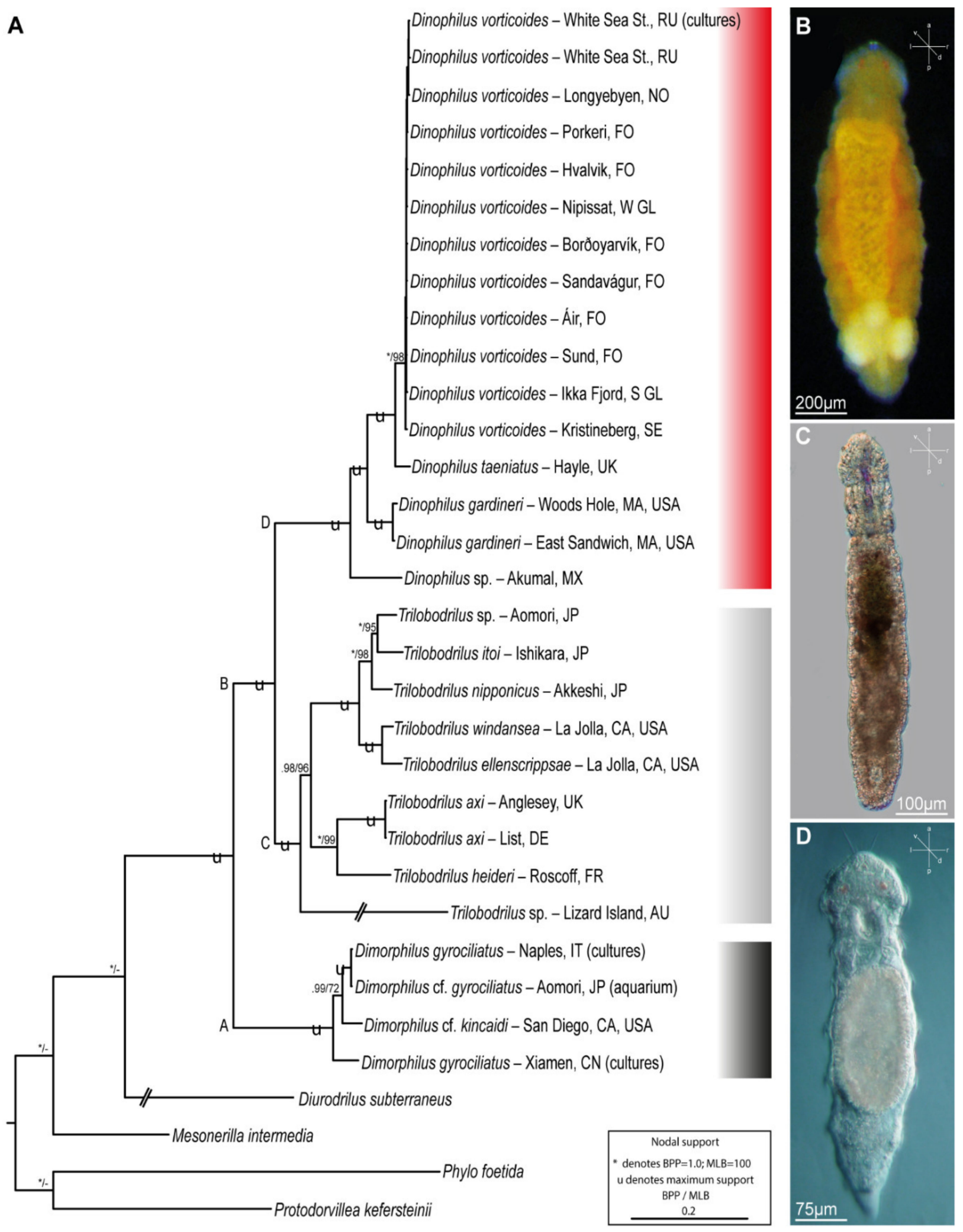

Figure 3. Phylogenetic relationships of Dinophilidae using combined gene analyses (18s rRNA, 28s rRNA, 16s rRNA, COI, $\mathrm{CytB}) ;(\mathrm{A})$ tree topology based on Bayesian analyses (BA) of combined gene datasets, nodal support indicated with Bayesian posterior probabilities (BPP) and maximum likelihood bootstrapping (MLB). Only nodal support above BPP $=0.5$ or MLB $=50$ shown, with those falling below threshold represented by a dash $(-)$. " $u$ " indicates maximum support $(\mathrm{BPP}=1.0$, MLB $=100)$. Color bars on right margin indicate three recovered clades: red, Dinophilus; $(\mathbf{B})$ grey, Trilobodrilus; $(\mathbf{C})$ black, Dimorphilus; (D). Small crosshairs indicate orientation. Images modified from [26]. 

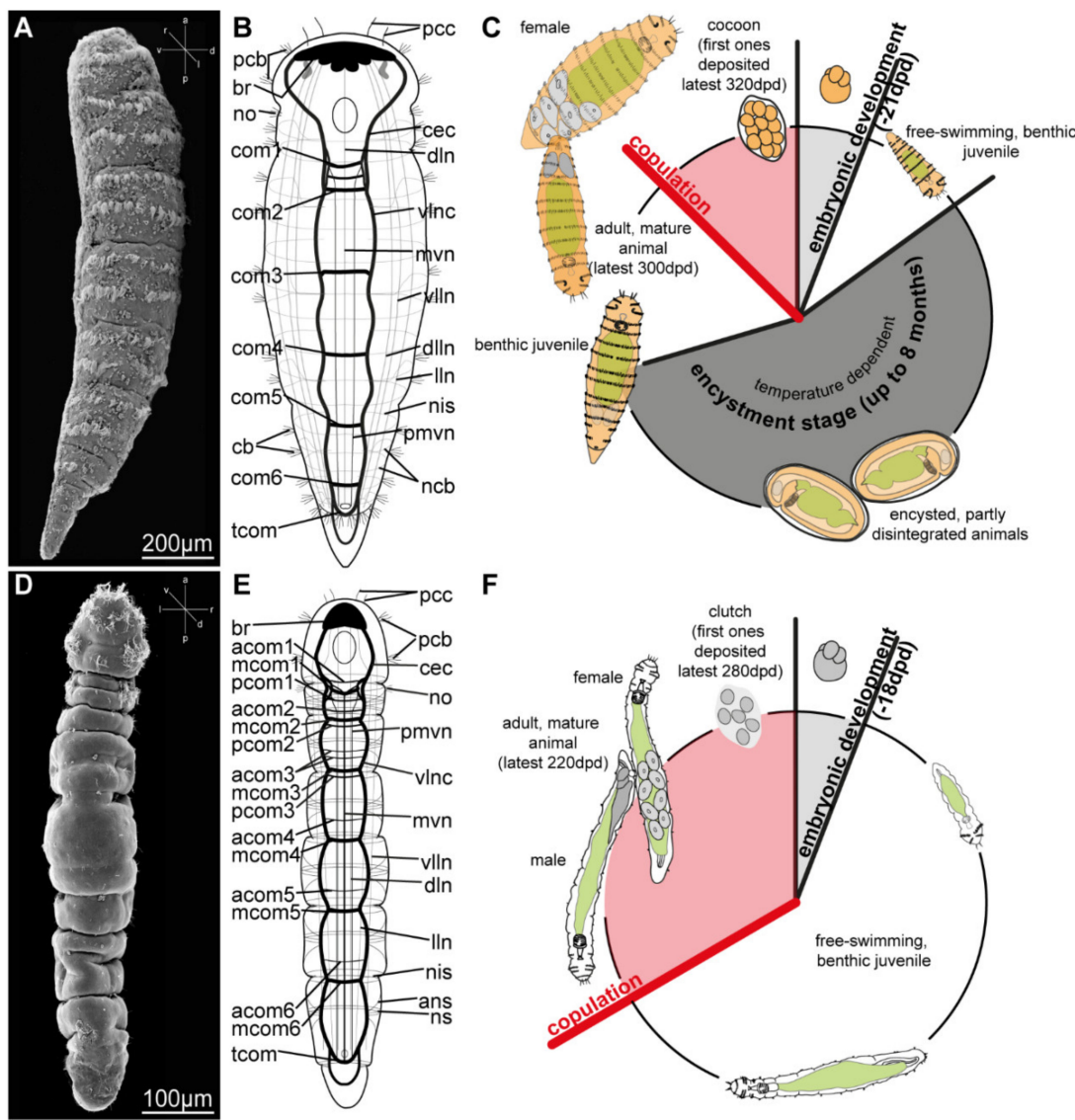

F
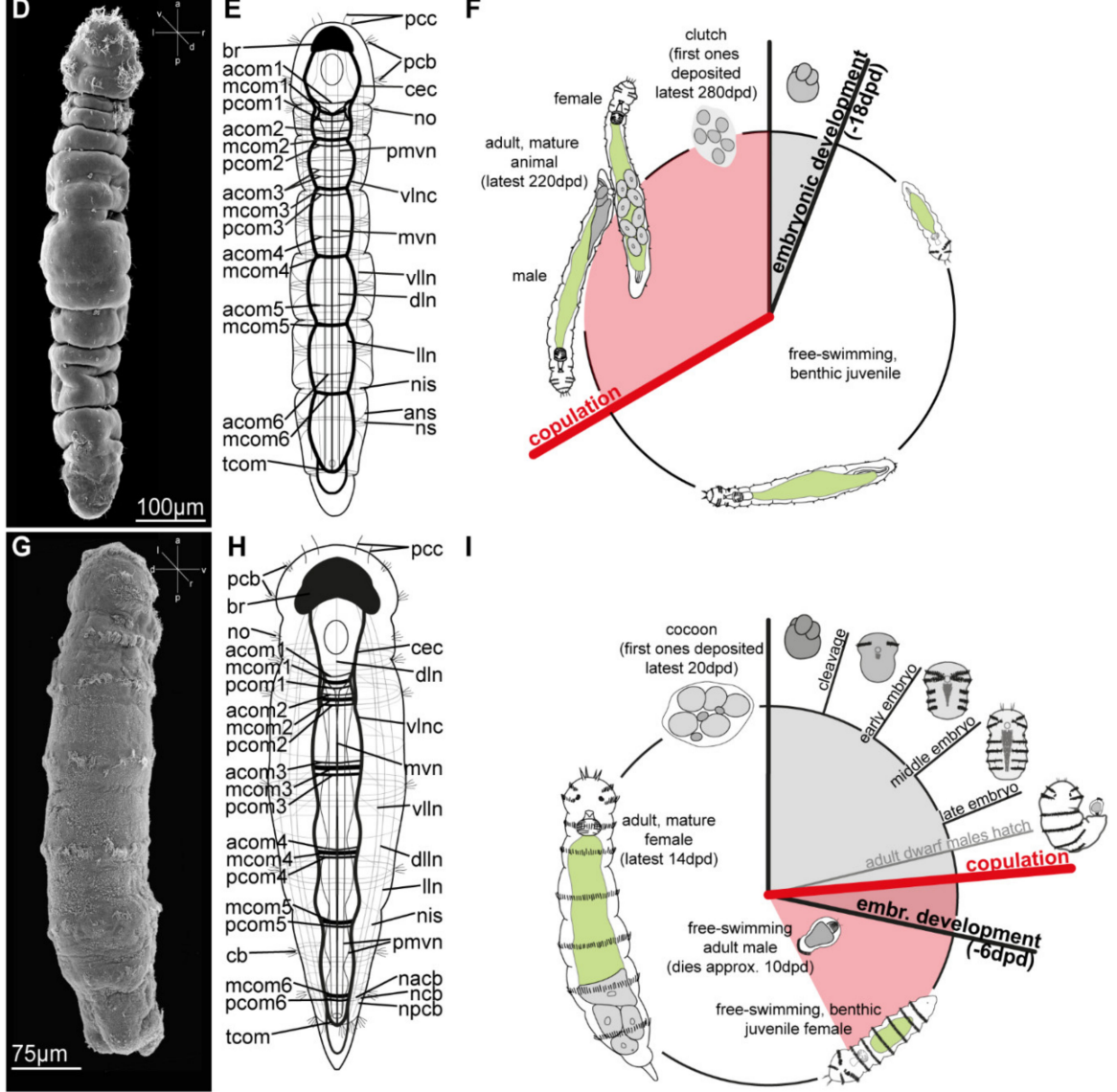

Figure 4. General external morphology, nervous system architecture and life cycle pattern of representatives of each of the three genera within Dinophilidae. (A-C). Dinophilus vorticoides (Faroe Islands); (D-F) Trilobodrilus axi (Sylt, Germany), (G-I) female Dimorphilus gyrociliatus. (A,D,G) Scanning electron micrographs illustrating external ciliation patterns (small crosshairs indicating orientation); (B,E,H) schematic reconstruction of the nervous system based on immunohistochemical labelling with anti-acetylated $\alpha$-tubulin and confocal laser scanning microscopy (CLSM) in ventral view; (C,F,I) schematic summary of the life cycles of D. vorticoides, T. axi and D. gyrociliatus based on literature review and personal observations, developmental time given in days post deposition (dpd). Abbreviations: a, anterior; acom, anterior commissures; ans, angled segmental nerve; br, brain; cb, ciliary band; cec, circumesophageal connective; com, commissure; d, dorsal; dlln, dorsolateral longitudinal nerve; dln, dorsal longitudinal nerve; drcc, dorsal root of the circumesophageal connective; l, left; lln, lateral longitudinal nerve; mcom, median commissure; mvn, medioventral nerve; nacb, nerve anterior to the ciliary band; ncb, nerve of the ciliary band; nis, intersegmental nerve; no, nuchal organ; npcb, nerve posterior to the ciliary band; ns, segmental nerve; p, posterior; pcb, prostomial ciliary band; pcc, prostomial compound cilia; pcom, posterior commissure; pmvn, paramedian nerve(s); r, right; tcom, terminal commissure; v, ventral; vlln, ventrolateral longitudinal nerve; vlnc, ventrolateral nerve cord. Images modified from [26,79]. 
All dinophilids have two pairs of stiff compound cilia located anteroterminally on the prostomium, and one pair of densely ciliated nuchal organs positioned laterally on the "neck" region (Figure 4A,D,G). Dinophilus and female Dimorphilus have a pair of beanshaped pigmented cup-type eyes (Figure 3B,D) [82,83]. Trilobodrilus lack such eyes but have anteriorly positioned ciliated organs underneath the prostomial epidermis [79,81], which most likely serve as light sensing organs. The epidermis has a range of glands, some of which show species characteristics in their vesicular or granular content, location, shape, and light refraction $[24,60,84,85]$.

The distribution of transverse ciliary bands or dorsal ciliation is generally genusspecific (Figure 4A,D,G). For instance, while other dinophilids have two incomplete ciliary bands on their prostomium (broken around the eyes), only species of Trilobodrilus lack dorsolateral ciliary bands on their trunk segments, with the exception of some lateral ciliary tufts in T. nipponicus or T. ellenscrippsae, for example (Figure $4 \mathrm{D},[54,61,76,85]$ ). Dimorphilus females have a single continuous transverse ciliary band per trunk segment (Figure 4G, [27,86,87]). Different types of dorsal ciliation are found within the genus Dinophilus, ranging from two continuous transverse ciliary bands on each trunk segment, with the last two occasionally being incomplete (e.g., D. vorticoides (Figure $4 \mathrm{~A}$ ) and $D$. taeniatus), to almost complete dorsoanterior ciliation with additional ciliary tufts between the ciliary bands in the posterior body in D. gardineri $[26,87]$.

Mature females can be identified by the presence of yolky eggs in the posterior body region, while unpaired male copulatory organs can be best observed in Dinophilus and Dimorphilus due to the refraction of their stylet glands [88]. An unpaired muscular copulatory organ is also present in Trilobodrilus, but less obvious.

Internally, all dinophilids have a thin layer of body wall musculature, which, depending on their size, varies between a more or less continuous layer of longitudinal muscles in the larger species of Dinophilus and ventrolaterally concentrated muscle bundles in Trilobodrilus and Dimorphilus. The longitudinal musculature is complemented by a thin outer layer of approximately equally spaced circular muscles $[75,78,79,88]$. The intestine is also surrounded by a thin muscle grid. All dinophilid species have a massive pharyngeal muscle bulb posterior to their mouth opening (Figure 3B-D), which is used to scrape or push off and transport biofilm from the substrate into the digestive tract [85,89]. All dinophilids have an anterodorsal brain with an internal neuropil and a surrounding somata-layer in the prostomium, as well as ventral nerve cords extending throughout the trunk (Figure $4 \mathrm{~B}, \mathrm{E}, \mathrm{H})$. The latter consists of a single pair of longitudinal ventrolateral nerve cords, one ventromedian nerve, one to two pairs of paramedian nerves, and different configurations of transverse commissures. Dimorphilus females have three transverse commissures in most segments (Figure 4H), Dinophilus has a single commissure per segment (Figure 4B), and Trilobodrilus has one prominent commissure complemented by a varying number of thin neurite bundles in each segment (Figure 3E, [75,78-81,88,90-96]).

The individual genera can be identified based on their size, coloration, and ciliation pattern using light microscopy (Figures 3B-D and 4A,D,G). Species identification requires the additional use of scanning electron microscopy to examine the detailed external morphology (e.g., to distinguish between Trilobodrilus-species, Figure 4A,D,G) and molecular analyses (e.g., for the distinction between D. vorticoides and D. taeniatus, [26]).

\subsubsection{Taxonomy}

Dinophilus O. Schmidt, 1848 (Figures 3B and 4A-C)

Diagnosis: All species are monomorphic, 1-3 mm long, brightly yellow to orangebrown and with cigar-shaped bodies that exhibit a broad ventral ciliary band and at least two transverse ciliary bands per segment (e.g., D. vorticoides, D. gigas, D. taeniatus and $D$. jaegersteni, $[53,97,98]$ ) or with complete dorsoanterior ciliation (D. gardineri). The life cycle of Dinophilus is the longest of the family, consisting of approximately three weeks to one month of embryonic development, with obligate, prolonged encystment stages lasting up to eight months in D. vorticoides, D. taeniatus, and D. gardineri $[97,99]$. 
Five species: Type species: Dinophilus vorticoides O. Schmidt, 1848; D. gigas Weldon, 1886, D. taeniatus Harmer, 1889; D. gardineri Moore, 1900; and D. jaegersteni Jones and Ferguson, 1957. Dinophilus caudatus Levinsen, 1880 and D. metameroides Hallez, 1879 were previously synonymized with $D$. vorticoides (Figures 3D and 4G-I, [100]).

Dimorphilus Worsaae, Kerbl, Vang and Gonzalez, 2019 (Figures 3B and 4A-C)

Diagnosis: Strong sexual dimorphism. Dimorphilus females are about $1 \mathrm{~mm}$ long with hyaline bodies, having a single transverse ciliary band per segment. Males are about $50 \mu \mathrm{m}$ long, extremely reduced in size and complexity, e.g., lacking a digestive system and mainly containing testes, gametes and a muscular copulatory organ [78,88,101,102]. Dwarf males are well-studied in D. gyrociliatus; however, they have not been observed in D. kincaidi [103]. Fertilized eggs are deposited in gelatinous cocoons, and the embryonic development takes roughly one week (slightly less in males, upon hatching immediately starting mating). Given their fast life cycle, Dimorphilus species can rapidly colonize new (and artificial) habitats and are often found in aquaria systems.

Two species. Type species: Dimorphilus gyrociliatus (O. Schmidt, 1857) and D. kincaidi (Jones and Ferguson, 1957). Dimorphilus apartis (Korschelt, 1882) and D. conklini (Nelson, 1907), were previously synonymized with D. gyrociliatus (see e.g., [104]). Dimorphilus pygmaeus (Verrill, 1892), should probably be synonymized with D. gyrociliatus, too, yet more detailed analyses are needed. Dimorphilus borealis (Diesing, 1862), D. simplex (Verrill, 1892) and $D$. rostratus (Schultz, 1902) were also reported, yet the latter two were morphologically assigned to Turbellaria and Rhabdocoela, respectively, and a platyhelminth affiliation was also suggested for $D$. borealis [53,75]. It is furthermore not possible to validate the taxonomic status of D. sphaerocephalus Schmarda, 1861, due to the inadequate description.

Trilobodrilus Remane, 1925 (Figures 3C and 4D-F)

Diagnosis: All species are monomorphic, but have a more elongated, slender, hyaline body than Dinophilus. In contrast to the other two genera, Trilobodrilus has reduced lateral and dorsal ciliation, and lacks pigmented eyes. While little is known about the life cycle of the subtidal species (T. heideri Remane, 1925 and T. ellenscrippsae), intertidal species have a life cycle of approximately one year with reproductive periods between April and July, and embryonic development taking between two and four weeks within a gelatinous egg clutch. Trilobodrilus lacks an encystment stage [105].

Eight species: Type species: Trilobodrilus heideri Remane, 1925; T. axi Westheide, 1967; T. indicus Rao, 1973; T. hermaphroditus Riser, 1999; T. nipponicus Uchida and Okuda, 1943; T. itoi Kajihara, Ikoma, Yamasaki and Hiruta, 2015; T. ellenscrippsae Kerbl, Vereide, Gonzalez, Rouse and Worsaae, 2018; T. windansea Kerbl, Vereide, Gonzalez, Rouse and Worsaae, 2018).

\subsubsection{Distribution and Diversity}

Integration of molecular, developmental and morphological studies have helped to further unravel the relationships and distribution of species [26,60]. However, with limited sampling and taxonomic efforts a substantial cryptic and hidden diversity is expected, e.g., an undescribed species was recently discovered off the coast of the Yucatán Peninsula in México [26]. The highest species number is found in the genus Trilobodrilus, while Dinophilus species have the broadest distribution range within the family $[26,53,75]$. Dinophilus species are restricted to shallow waters and the intertidal areas of rocky or sandy shores. Most Dinophilus species inhabit the cold waters throughout the Atlantic, with $D$. vorticoides having the broadest distribution range, spanning from the west coast of Greenland to the White Sea, Russia [26]. In contrast, D. taeniatus has only been found along the west coast of the United Kingdom [106], and D. gardineri appears to be limited to the coast off Massachusetts [87]. Explanations for these varying distribution patterns are mainly speculation. However, it is likely that the lack of larval dispersal stages and a limited ability to migrate over long distances, as well as the temperature optimums during the different life cycle stages, has hampered a broad distribution in most species. On the other hand, stages of lengthy encapsulation, such as the encysted juveniles in Dinophilus-species or 
eggs deposited in gelatinous "cocoons", might increase dispersal abilities via rafting on algae, sediment, or debris, being at the whims of prominent currents.

Trilobodrilus prefers coarse, well-sorted sandy sediments from the eulittoral zone down to several meters depth $[60,75,107]$. Bathymetric ranges seem to be clearly demarcated, resulting in eu- and sublittoral species occurring at the same beach in close proximity to each other $[60,84]$.

Very little is known about the distribution pattern of Dimorphilus, yet preliminary analyses found geographically widely separated populations to be genetically closely related [5]. However, most of these specimens came from old aquarium cultures, which could have been mixed over time, as the geographical origin cannot be verified. A "real" global distribution pattern of one species across Brazil, USA, Italy, Germany, Russia, and Japan as indicated by $[5,26,108]$ warrants further studies on wild caught material [26].

\subsubsection{Major Revisions and Most Important Literature}

The most recent reviews of the family were given by Westheide [75] and Worsaae et al. [26]. The latter study [26] revised the genus Dinophilus and especially the relationship between the morphologically similar $D$. vorticoides, described in the Faroe Islands, and $D$. taeniatus described in the United Kingdom. D. vorticoides was here recognized as a valid taxon with a remarkably broad distribution in the boreal North Atlantic, while D. taeniatus was only found near its type location [26]. Populations previously reported along the French coast of the English Channel remain of particular interest, since their collection and identity will allow for interpretations of the ecological, developmental and physiological limits of the distribution ranges between $D$. vorticoides and D. taeniatus. Molecular analyses of Trilobodrilus species collected from several locations worldwide recovered taxa adapted to intertidal and subtidal sediments, respectively, for each geographical region [27,61,85]: T. axi-T. heideri in the Northwest Atlantic, T. itoi-T. nipponicus around Japan, T. indicus along the Indian coast and T. windansea-T. ellenscrippsae along the west coast of the United States (Figure 3A). Although specimens of Dimorphilus cf. gyrociliatus were collected from different locations in Europe (Naples, laboratory aquaria in Russia, Sweden and Denmark) as well as from Israel, USA, and Japan, their identity has only been analyzed superficially so far (Figure 3A, [26]).

\subsection{Diurodrilidae Kristensen and Niilonen, 1982}

\subsubsection{Phylogenetic Affinities}

The phylogenetic position of the microscopic members of Diurodrilidae has long been debated due to their lack of significant annelid characteristics, such as chaetae, head appendages, parapodia, nuchal organs and obvious segmentation (Figure 5). The first described species of Diurodrilus was assigned to Dinophilidae by Remane (1925) as part of the now-abandoned "Archiannelida" [7,109]. However, diurodrilids lack the characteristic continuous midventral ciliary band of most interstitial annelids. Their ventral side instead carries specialized multiciliated cells, called ciliophores. Diurodrilids also possess a ventral bowl-shaped muscular pharynx that differs from that of Dinophilidae, yet these animals have a reduced cuticle, showing some resemblance to other interstitial and juvenile annelids [14,24]. Their unique morphology was acknowledged by Kristensen and Niilonen [110] when they erected Diurodrilidae Kristensen and Niilonen, 1982, then by Westheide [111] in erecting Diurodrilida, and finally Worsaae and Rouse [14] questioned their annelid affinity based on a phylogenetic study of $18 \mathrm{~S}$ rRNA and 28S rDNA data, which placed them outside Annelida. Moreover, diurodrilids have several traits in common with other meiofaunal metazoans, and particularly Gnathifera, such as the presence of trunk ciliophores with long ciliary rootlets, adhesive head and toe glands, spermatozoa with mushroom bodies, dorsal plates and a ventral muscular pharynx with large central glands [14]. However, a later mitochondrial genome study [112] and three comprehensive phylogenomic studies $[8,11,12]$ found Diurodrilidae to nest within annelids. Although their exact position is not fully resolved, the latter two studies grouped Diurodrilus with 
another meiofaunal annelid taxon, Apharyngtus (within Orbinida), which at least shows some superficial morphological resemblance to Diurodrilidae [53,71]. The very small size, aberrant morphology and poorly segmented nervous system of Diurodrilus have therefore been discussed to possibly reflect an extreme case of pedomorphosis within Annelida [7,11,14,25].

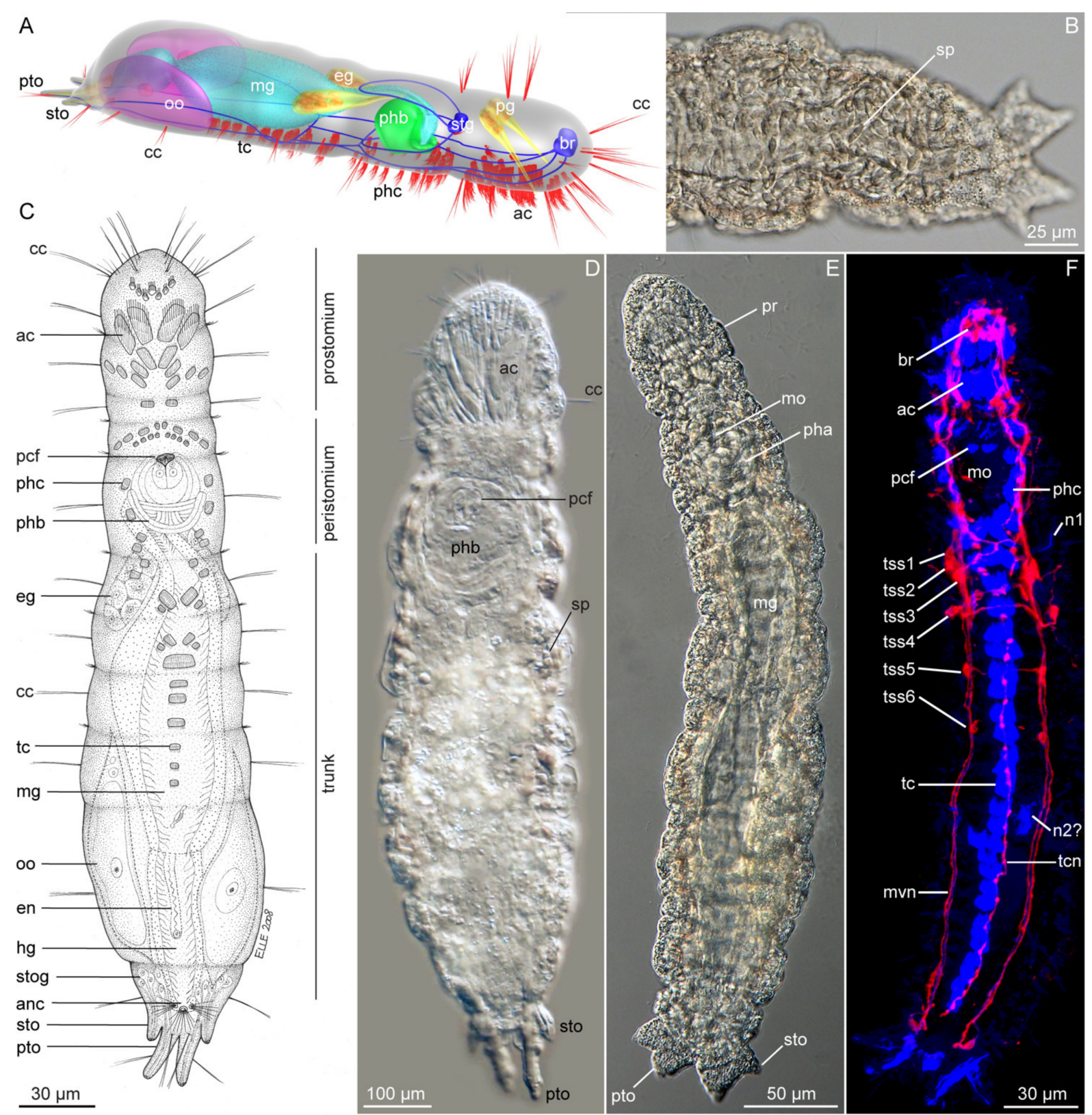

Figure 5. (A) Schematic illustration of Diurodrilus sp. from South Australia, Australia; (B) light micrograph of posterior trunk of D. subterraneus male with sperm. (C) Drawing of Diurodrilus sp. from Queensland, Australia, ventral side. (D) Light micrograph of male Diurodrilus sp. from Aomori, Japan. (E) Light micrograph of female D. subterraneus. (F). Confocal laser scanning microscopy (CLSM), maximum intensity projection of Z-stack images of D. subterraneus showing anti-acetylated $\alpha$-tubulin like immunoreactivity (LIR) (blue) and anti-serotonin LIR (red). (C,E,F)—modified from [25]. Abbreviations: ac, anterior head ciliophore; anc, anal ciliary field; br, brain; cc, compound cilia; eg, esophageal gland; en, enteronephridium; hg, hindgut; mg, midgut; mo, mouth opening; mvn, main ventral nerve; n1-2, nephridium 1 and 2; pcf, prepharyngeal ciliary field; pg, prostomial gland; pha, pharynx; phb, pharyngeal muscle bulb (bowl-shaped); phc, peripharyngeal ciliophore; pr, prostomium; pto, primary toe; oo, oocyte; oon, oocyte nucleus; sp, spermatozoa; sto, secondary toe; stog, secondary toe gland; stg, stomatogastric ganglion; tc, trunk ciliophore; tcn, trunk ciliophore nerve; tss1-6, first to sixth pairs of trunk anti-serotonin LIR somata. 
Only a single genus, Diurodrilus, has been described, reflecting a rather similar morphology across the seven described species. A phylogenetic study of the family that included three gene fragments from three species [113] did not group the two species from the East Pacific, but instead grouped the two upper littoral species D. kunii and D. subterraneus, which also show closer morphological resemblance. An ongoing phylogenetic study of the family across multiple species (Worsaae et al. unpublished) aims to test the degree of endemism among the European populations and whether possible adaptations to subtidal versus littoral habitats may be reflected in their phylogenetic relationships, despite their presumably more restricted dispersal potential of intertidal species.

\subsubsection{Morphology}

All members of Diurodrilidae are microscopic, dorso-ventrally flattened, hyalin and fast moving. Their 300-500 $\mu \mathrm{m}$-long body comprises an elongated head region and a short, seemingly unsegmented coelomate trunk with two to four pygidial lobes (toes) and sometimes an anal cone (Figure 5). The prostomium carries long, presumably sensory, compound cilia that are also found along the lateral trunk. The peristomium has a ventral mouth opening and a bowl-shaped muscular pharynx with central paired glands. Along the entire ventral surface are the characteristic ciliophores (multiciliated cells with long ciliary rootlets), where the cilia of each cell beat in unison. The ciliophores are large and ovoid on the prostomium but rectangular on the peristomium and trunk. The ciliophores surrounding the mouth opening continue along the trunk as transverse rows of rectangular ciliophores, forming a discontinuous midventral band (Figure 5) [7,14,25,110].

Paired, long-necked adhesive glands open ventrally on the prostomium and at the tip of the pygidial toes, while two large salivary (esophageal) glands extend posteriorly to the muscular bulb. Diurodrilids glide quickly by way of ciliary beating of the ciliophores, intermittently adhering (and releasing) the head and/or the toes to the substrate, somewhat resembling the motility pattern of gastrotrichs. Their rapid release from substrate (post adhesion) indicates a duo-gland function of the diverging gland types found in the primary and secondary toes $[7,14,25,110]$.

Diurodrilids possess an unsegmented, grid-like body wall musculature composed of two main and several thinner circular muscles. Inner circular musculature surrounds the intestine, some of which may act as sphincter muscles between the mid and hindgut as well as around the anus [14].

The only detailed study of the nervous system [14] showed an anterior bilobed brain and only a few anterior ganglia along the widely separated two main, and four minor ventral nerves, hereby defying the previous externally assessed interpretation of the trunk consisting of five segments. Likewise, only two pairs of protonephridia are found in the anterior and middle trunk $[7,14,110,113]$. Although their presence and lateral openings have been documented in four species using TEM, CLSM and SEM, their exact configuration and composition are still not fully understood and may vary slightly among species [26]. A third pair of densely ciliated ducts, presumably representing gonoducts, is found opening ventrally in the posteriormost trunk [25]. However, the paired ovaries or testes seem to disappear during development, with the gametes consequently lying freely in the coelomic cavity, being most prominent in the dorsal part of trunk and lacking an obvious peritoneal lining $[7,14,110,114]$. Diurodrilids are seemingly all direct developers and gonochoristic, with males producing specialized spermatozoa with large acrosomes and mushroom-shaped bodies [114]. An unpaired, ciliated, blind-ending enteronephridium extends along the hindgut from the dorso-posterior midgut in Diurodrilus sp. from Brisbane, Australia [25].

\subsubsection{Taxonomy}

The different species of Diurodrilus are distinguished by variation in ciliophore patterns, glandular patterns, absence/presence of cuticular plates, length of the toes and shape of the spermatozoa. Accompanying molecular barcoding and perhaps even population ge- 
netics might prove necessary in order to describe the vast hidden diversity of Diurodrilidae. The systematically important cilliophore patterns are best examined using anti- $\alpha$-tubulin staining and CLSM, and alternatively, by meticulous high-resolution light microscopy on live animals. Key features of described species are listed in Table 1.

Table 1. Diagnostic characters of described species of Diurodrilus.

\begin{tabular}{|c|c|c|c|c|c|c|c|}
\hline $\begin{array}{l}\text { Species of } \\
\text { Diurodrilus }\end{array}$ & $\begin{array}{c}\text { Intertidal } \\
\text { (I)/Subtidal (S) }\end{array}$ & $\begin{array}{c}\text { Primary } \\
\text { Toes Longer } \\
\text { than } \\
\text { Secondary } \\
\left(2^{\circ}\right) \text { Toes }\end{array}$ & $\begin{array}{c}\text { Shape of } \\
\text { Primary Toes }\end{array}$ & $\begin{array}{c}\text { Shape of } \\
\text { Secondary } \\
\text { Toes }\end{array}$ & $\begin{array}{l}\text { Anal } \\
\text { Cone }\end{array}$ & $\begin{array}{c}\text { Ciliophores } \\
\text { on Anterior } \\
\text { Head }\end{array}$ & $\begin{array}{c}\text { Dorsal } \\
\text { Cuticular } \\
\text { Plates }\end{array}$ \\
\hline D. ankeli & I & yes & cylindrical & cone shaped & absent & 4 pairs +1 & present \\
\hline D. benazzii & I & no $2^{\circ}$ toes & $\begin{array}{l}\text { bottle- } \\
\text { shaped }\end{array}$ & no $2^{\circ}$ toes & absent & 3 pairs & absent \\
\hline D. dohrni & $I+S$ & yes & $\begin{array}{l}\text { bottle- } \\
\text { shaped }\end{array}$ & cone shaped & absent & unknown & unknown \\
\hline D. kunii & I & yes & cylindrical & cone shaped & absent & 3 pairs & absent \\
\hline D. minimus & $\mathrm{I}+\mathrm{S}$ & equal & cylindrical & cone shaped & small & unknown & absent \\
\hline $\begin{array}{l}D . \\
\text { subterrraneus }\end{array}$ & I & yes, slightly & cone shaped & cone shaped & absent & 5 pairs & present \\
\hline D. westheidei & S & yes & cylindrical & cylindrical & large & 3 pairs & absent \\
\hline
\end{tabular}

Diurodrilus Remane, 1925

Seven described species. Type species: Diurodrilus minimus Remane, 1925; D. subterraneus Remane, 1934; D. benazzii Gerlach, 1952; D. dohrni Gerlach, 1953; D. ankeli Ax, 1967; D. westheidei Kristensen and Niilonen, 1982; D. kunii Kajihara, Ikoma, Yamasaki and Hiruta, 2019. Ten unidentified species of Diurodrilus have additionally been found along the Atlantic coast of the USA [25], Galapagos Islands [115], New Zealand ([74], two species), northeast and southern Australia ([14,116]; two species), Tobago and Trinidad (K. Worsaae and R. M. Kristensen, unpublished), Brazil (M. Di Domenico, pers. comm.), Northern Cuba (K. Worsaae, unpublished), Aomori, Japan (K. Worsaae, unpublished), and Amsterdam Island, southern Indian Ocean (K. Worsaae, unpublished). Moreover, some of the multiple sampled populations of Diurodrilus cf. minimus and D. cf. subterraneus in the North Atlantic and D. cf. dohrni in Canary Island waters and the Mediterranean Sea may represent new cryptic species (Worsaae, unpublished).

\subsubsection{Distribution and Diversity}

Diurodrilids are only recorded from intertidal and shallow subtidal waters (less than $60 \mathrm{~m}$ depth). They prefer fine to coarse, well-sorted, oxygenated sediment. Most records are from European waters, but they are found in all major oceans worldwide, from polar to tropical regions ([25] and references herein).

The limited number of easily distinguishable external characteristics has most likely led to the arrest in the description of new species of Diurodrilidae in recent years. However, unpublished molecular data (K. Worsaae et al.) indicate a high hidden diversity similar to what is seen in other interstitial annelid families, with different species existing even within short geographical distances.

\subsubsection{Major Revisions and Most Important Literature}

The morphological diversity of Diurodrilidae has mainly been addressed by Kristensen and Niilonen [110], Villora-Moreno [117], Worsaae and Rouse [14], Westheide [53] and Worsaae [3], whereas the study by Kajihara et al. [113] was the first to compare molecular sequences among species of Diurodrilidae. 


\subsection{Lobatocerebridae Rieger, 1980}

3.4.1. Phylogenetic Affinities

Lobatocerebridae is a family of rare and inconspicuous meiobenthic annelids $[15,118,119]$. Superficially, they do not share any morphological traits exclusively with annelids. However, their phylogenetic position among Annelida has been settled thanks to phylogenomics [8]. They are filiform, cylindrical, and completely ciliated worms lacking appendages, with a length ranging between 1 and $3 \mathrm{~mm}$ and a width of 40-100 $\mu \mathrm{m}$ (Figure 6A,F). The first described species, Lobatocerebrum psammicola, was assigned to Annelida. However, this phylogenetic position has been repeatedly questioned given their ambiguous morphological characters, leading to the subsequent erection of Lobatocerebromorpha as phylum [120,121]. It was only in 2015 that transcriptomic-based phylogenetic studies confirmed its affinities with Annelida and found it as a sister group to Sipuncula (albeit with low support) [8]. More recently, new studies placed Lobatocerebrum as the sister group to Dinophilidae, forming the clade Dinophiliformia [12], reciprocally monophyletic to the clade Pleistoannelida (ErrantiaSedentaria) (Figure 1).

\subsubsection{Morphology}

Lobatocerebridae are elongated animals, $1-3 \mathrm{~mm}$ long and $40-110 \mu \mathrm{m}$ wide, with a body circular in cross-section and completely ciliated $[15,118]$. All lobatocerebrids lack segmentation and appendages. The densely ciliated pharynx (Figure 6D) is followed by an unciliated gut and a ciliated hindgut (Figure 6D,F) that terminates at a dorsal, subterminal anus. All species have a large, transparent, multilobed brain (hence the etymology of "Lobatocerebrum"; Figure 6C) positioned posteriorly in the rostrum, anterior to the mouth (Figure 6F). The highly glandular epidermis gives the animal a slightly greenish hue. The longitudinally elongated ventral mouth (Figure 6D,F) marks the border of the proportionally long rostrum (ca. 20-30\% of the body length) and the trunk (Figure 6A,F).

Lobatocerebrum is hermaphroditic. The anterior-most reproductive structure is an unpaired testis, positioned approximately halfway along the body, containing elongated filamentous sperm cells. A pair of spermioducts (100-200 $\mu \mathrm{m}$ long) extend anteriorly from the testis and open in an unpaired, antero-dorsal gonopore surrounded by numerous elongated glands (Figure 6F). Posteriorly, approximately two thirds along the body, up to four oocytes can be found, which increase in volume and length posteriorly ( $\leq$ couple of hundred micrometers). No ovarium, oviduct, or female opening has been described [15,118]. Anterior to the hindgut, one to several 20-30 $\mu \mathrm{m}$-wide seminal receptacles with ventrolateral openings were found, containing curled up sperm cells (Figure 6F). Lobatocerebrum supposedly has direct development, but observations and studies to confirm this are lacking.

The nervous system consists of a relatively large brain with a prominent neuropil, two pairs of segmentally arranged ganglia, anterior and posterior longitudinal nerves emerging from the neuropil (Figure 6C,F), five commissures and a peripheral nervous system [15,118]. The brain comprises three pairs of lobes (and sublobes hereof): anterior major rostral lobes and posterior pairs of minor and caudal lobes, respectively. Originating at the brain, four paired and one unpaired nerve extend through the rostrum, possibly innervating sensory cells and glands in the anterior-most tip of the animal. Two ventrolateral nerves extend posteriorly from the brain connected by the commissures of two pairs of post-pharyngeal ganglia localized posterior to the mouth opening. Each ganglion of the anterior-most pair supplies an additional nerve extending ventromedially. These nerves fuse medially with their contralateral partner at the level of the second commissure, forming an unpaired midventral nerve and extending posteriorly to the posterior-most (fifth) commissure alongside the two ventrolateral nerves. The third, fourth, and fifth posterior commissures are not associated with any ganglia. Additionally, a stomatogastric nerve ring is found encircling the mouth. 
A

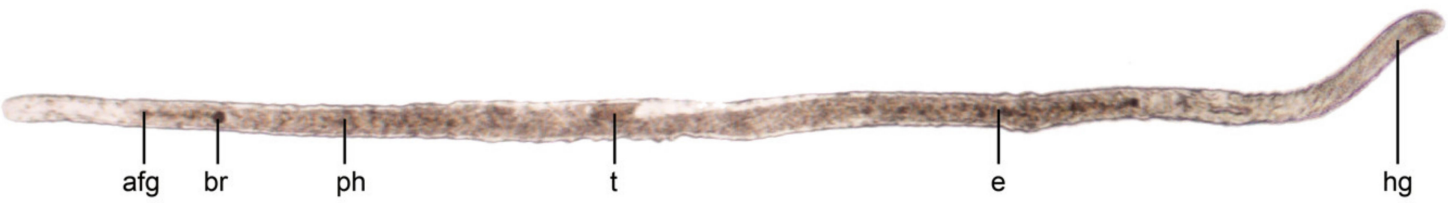

$100 \mu \mathrm{m}$
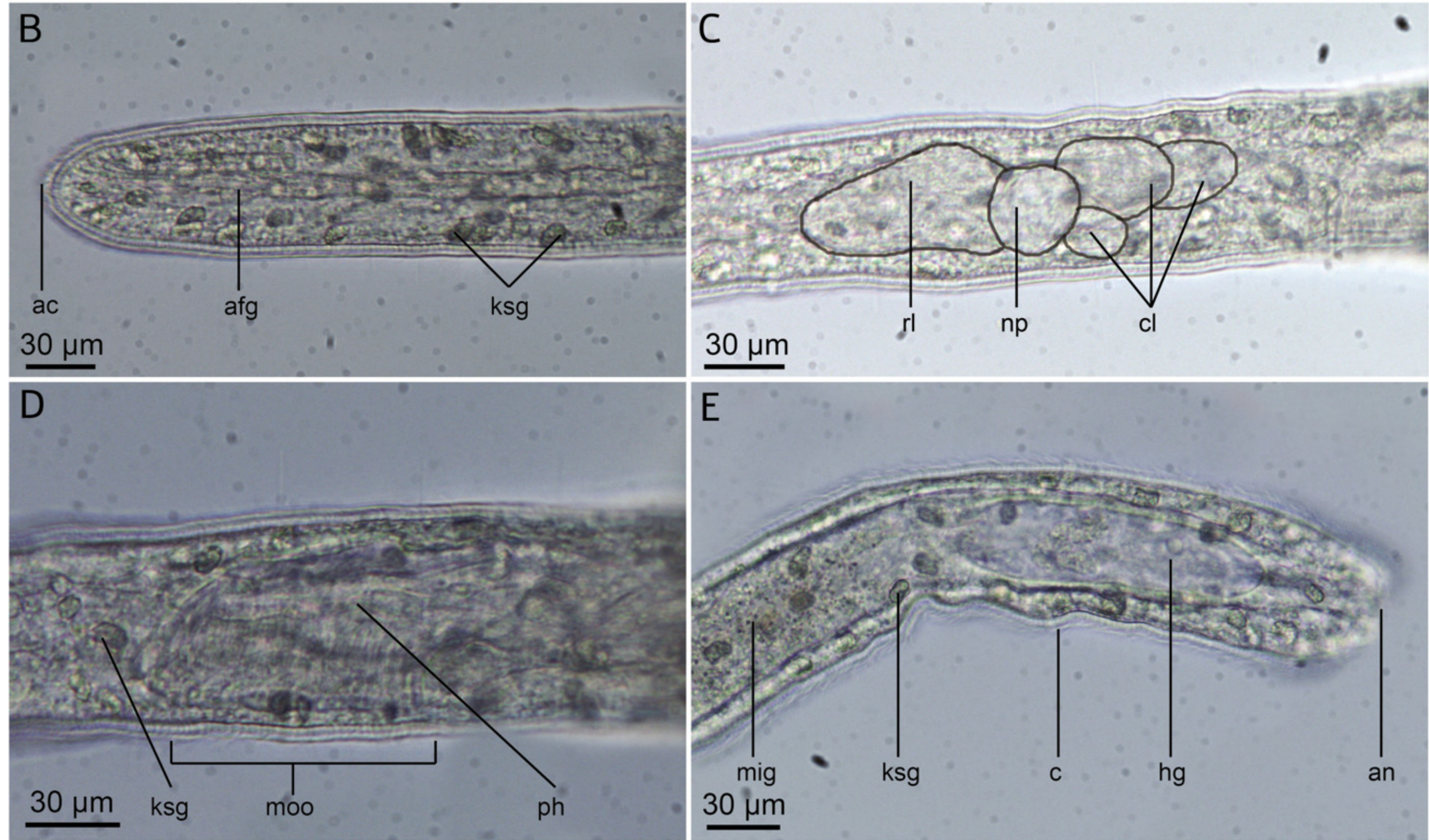

$\mathrm{F}$

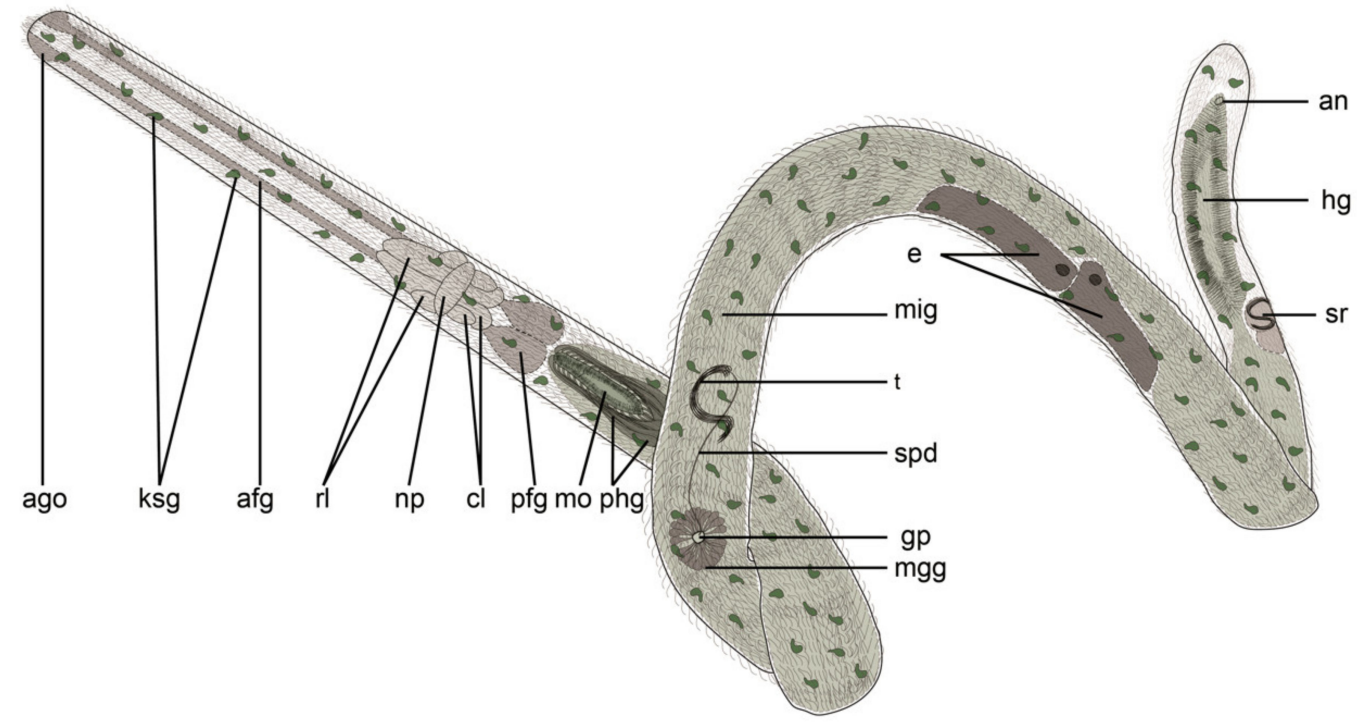

Figure 6. Morphology of Lobatocerebridae with illustrations of Lobatocerebrum riegeri (b-f, modified from [15]). Anterior is to the left and posterior is to the right. (A,B,F) Dorsal view. (C,D) Lateral view, ventral is down, and dorsal is up. (A-E) Light micrographs of L. riegeri. (A) Habitus of L. riegeri. (B) Close up of the tip of the rostrum. (C) Close up of the brain. (D) Close up of the mouth area. (E) Close up of the posterior end. (F) Schematic drawing of L. riegeri. Abbreviations: ac, anterior ciliation; afg, anterior frontal glands; ago; anterior frontal gland opening; an, anus; br, brain; c, body ciliation; cl, caudal lobe(s) of the brain; e, egg; gp, gonopore; hg, hindgut; ksg, kidney shaped glands; mgg, male gonopore glands; mig, midgut; mo, mouth; moo, mouth opening; np, neuropil; pfg, posterior frontal glands; ph, pharynx; rl, rostral lobe(s) of the brain; spd, spermioduct; sr, seminal receptacle; $t$, testes. 
The muscular system consists of the body wall and gut musculature. The body wall musculature consists of six pairs of longitudinal muscles extending along the entire body length $[15,122]$. Regularly spaced muscle ring complexes are associated with these longitudinal muscles in the trunk, consisting of transverse muscle fibers extending perpendicularly from one longitudinal muscle to the next one, together giving the impression of unusual internal positioned circular musculature. This organization more closely resembles the transverse muscles of other annelids than their normally externally positioned circular musculature [123]. In the rostrum, these transverse muscles cross centrally to form a starshaped grid of muscles in cross section. The musculature of the intestinal system comprises a muscular grid of longitudinal and perpendicularly arranged circular muscle fibers lining the entire digestive tract. Five circular sphincters are found supporting the pharynx, and a sixth sphincter is located anterior to the anus.

Lobatocerebrum possesses four types of unicellular gland and three types of multicellular gland [15,118,119,124]. Unicellular glands are characterized as: (1) regular scattered mucus glands, which are the largest unicellular glands with thick microvilli around the opening. The nucleus is found at the basal end and the cell body is densely packed with spherical vesicles. A long cell projection, several time longer than cell body, extends along the basal membrane. (2) Tubular glands, which are elongated and flask-shaped, with a basal projection along the basal lamina. The glandular content consists of small, rod-like granules. They are randomly distributed throughout the body, at least in L. riegeri. (3) Kidney-shaped gland cells, which are densely packed with spherical vesicles, but do not have a basal projection (Figure 6B,D,F). The dense packing of the granules affects the nucleus, which takes on a characteristic sickle shape. (4) Adhesive glands, which possess a ciliary ring around the opening, which is encircled by an anchor cell. The granules of these cells differ between the two described species in having rod-like electron-dense inclusions in L. psammicola, and granule-shaped (shorter) inclusions in L. riegeri.

Multicellular gland systems include: (1) two pairs of frontal glands (Figure 6A,B,F); an anterior pair of frontal glands lying anterior to the brain with elongated rod-shaped granules, and a pair of posterior frontal glands with spherical granules situated between the brain and the pharynx (Figure 6F). The ducts of these glands extend ventrolaterally throughout the rostrum and seem to release the glandular secrete mainly at the tip of the rostrum. (2) Pharyngeal glands, constituted by multiple epidermal glands whose duct openings encircle the mouth (Figure 6F). (3) Male gonopore glands, comprised of two different gland types in L. psammicola, and apparently only one in L. riegeri (Figure $6 \mathrm{~F}$ ). These cells resemble the pharyngeal glands in shape, size, and electron-density, but are arranged around the gonopore.

Lobatocerebrum psammicola was suggested to have three pairs of U-shaped protonephridia based on squeezed preparations and live observations of cyrtocyte-like structures [118,125]; however, only one nephridium, located posterior to the testis, was reported for L. riegeri (as Lobatocerebrum sp. II [118]).

\subsubsection{Taxonomy}

Lobatocerebrum Rieger, 1980

Two described species: Type species, Lobatocerebrum psammicola Rieger, 1980; L. riegeri Kerbl, Bekkouche, Worsaae, Sterrer, 2015. Species of Lobatocerebrum are diagnosed based on the proportional measurements of the body [15]: Lobatocerebrum psammicola is larger than $L$. riegeri in total length (2-3 mm vs. $1-1.5 \mathrm{~mm}$, repectively) and diameter (40-60 $\mu \mathrm{m}$ vs. $70-110 \mu \mathrm{m}$, repectively), but has a shorter rostrum (15\% vs. $20 \%$ of the body length, respectively), and a more anterior brain (at $10 \%$ vs. $18 \%$ of the body length, respectively) and mouth (at $14 \%$ vs. $20 \%$ of the body length, respectively). Other differences concern the inclusion in the granules of unicellular adhesive glands, which are rod-shaped in L. psammicola and more spherical (shorter) in L. riegeri $[15,119]$. So far, only specimens collected at Bocas del Toro, Panama have been sequenced for transcriptomic analyses, morphologically closely resembling L. psammicola or a cryptic species hereof [8]. Few 
additional sightings in the North Atlantic near Gran Canaria (Spain), the Mediterranean Sea near Elba (Italy), and possibly a location off Elsinore (Denmark) may represent additional new cryptic species (W. Sterrer, R. M. Kristensen, K. Worsaae, pers. comm.).

\subsubsection{Distribution and Diversity}

Lobatocerebrum is found in very low densities and abundances in different kinds of sediments: Lobatocerebrum psammicola is found in heterogenous medium-coarse sandy sediment off North Carolina but has also been reported in coral rubble (not well-sorted, mixed fine and coarse sediment) at Bocas del Toro, Panama [8]. Lobatocerebrum riegeri is found in coarse calcareous sand in Eilat, Israel. Dr. Wolfgang Sterrer has also found lobatocerebrids in fine sandy sediments underneath Zostera meadows around Gran Canaria (Canary Islands, Spain) and in southern Italy (Mediterranean Sea [119]).

\subsubsection{Major Revisions and Most Important Literature}

A recent morphological study [15] as well as [119] reviewed and summarized most of the extensive TEM and histology studies done previously [118,122,124,125].

\subsection{Nerillidae Levinsen, 1883}

\subsubsection{Phylogenetic Affinities}

Nerillidae contains 14 valid genera with 59 meiofaunal species, ranging in size from $300 \mu \mathrm{m}$ to $2.1 \mathrm{~mm}$ and comprising seven to nine segments (Figure 7). Nerillids possess several morphological traits normally considered apomorphic for Errantia, including compound chaetae, one pair of pygidial cirri, a muscular ventral pharyngeal organ, prostomial antennae and short (except in Speleonerilla), non-grooved ventrolateral palps (Figure 8). The meiofaunal sizes and resemblance to early juvenile stages of Syllidae and Eunicidan taxa support a progenetic origin for the family, possibly from an ancestor within Errantia $[7,126,127]$. Early molecular studies likewise found support for their relatedness to errantian families, although the exact position remained debated [128]. However, one phylogenomic study recovered Nerillidae close to Orbiniidae within Sedentaria [11]. Recent morphological [13] and ongoing phylogenomic studies (K. Halanych, pers. comm.), however, continue to support a position within Errantia.

The genera-to-species ratio is quite high in Nerillidae, with many of the 14 valid genera being monotypic, yet, several genera have already been synonymized, including Afronerilla herein with Nerillidium, see below. Nerillids easily shed their appendages during the fixation processes, necessitating live examination and complicates gathering sufficient information for taxonomic descriptions. Furthermore, species may be diagnosed based on subtle differences in ciliary and glandular patterns, morphometrics of the body, appendages and chaetae (preferably on living individuals), as well as on the configuration of both nephridia and gonoducts. Taxonomic descriptions thus necessitate a broad range of fixation and examination techniques, including light- and scanning electron microscopy as well as immunolabelling and confocal laser scanning microscopy. In recent years, molecular studies have revealed a high diversity of cryptic species that can only be resolved by sequencing multiple genes, preferably from several specimens within each population, e.g., [37]. 
A

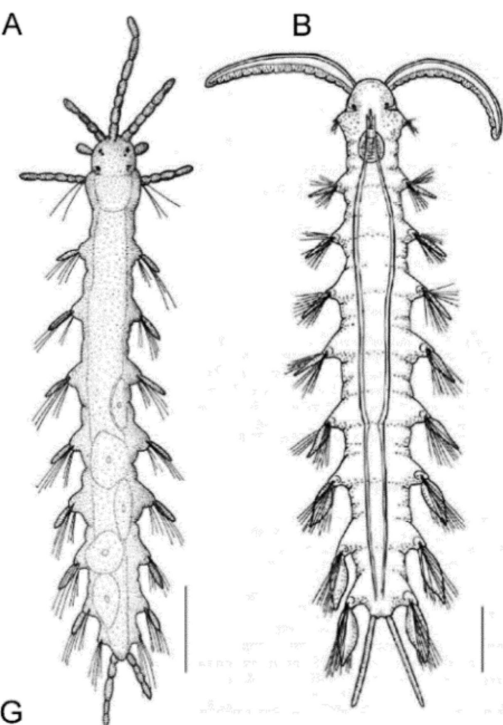

G

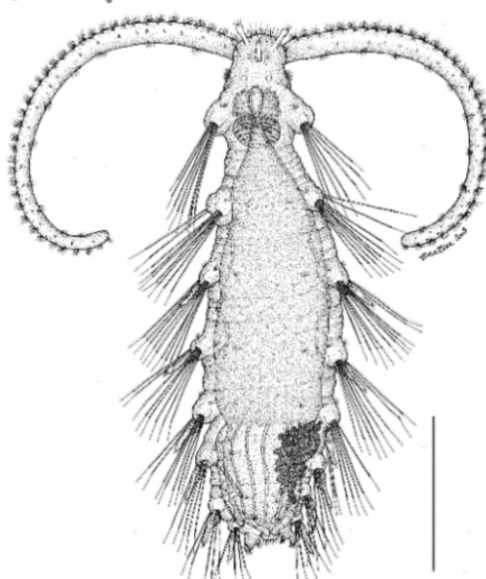

L

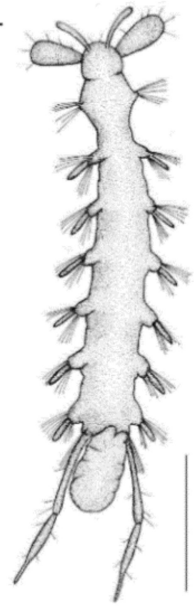

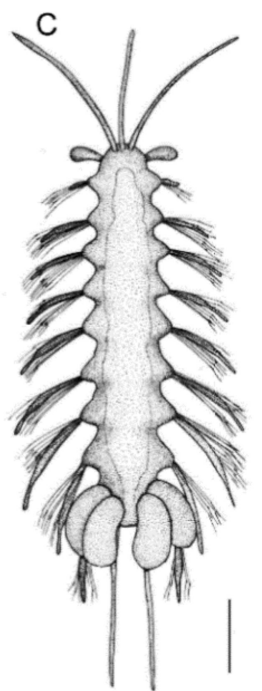
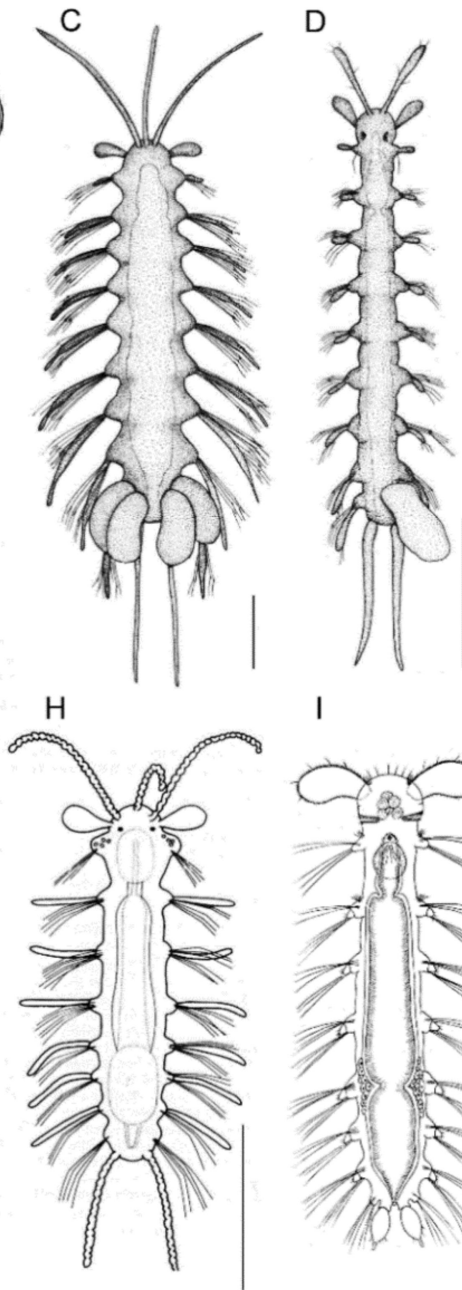

I

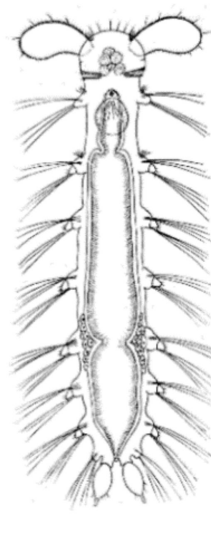

E

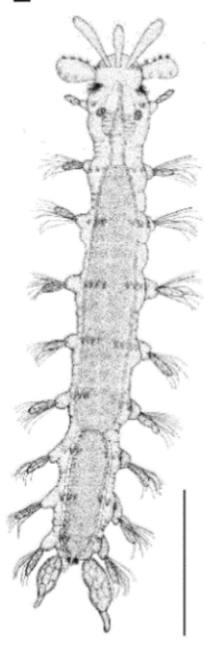

J

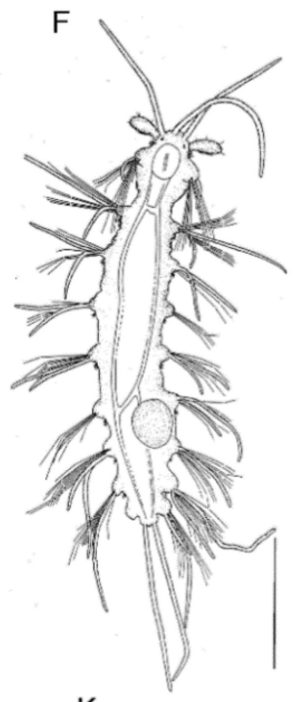

K
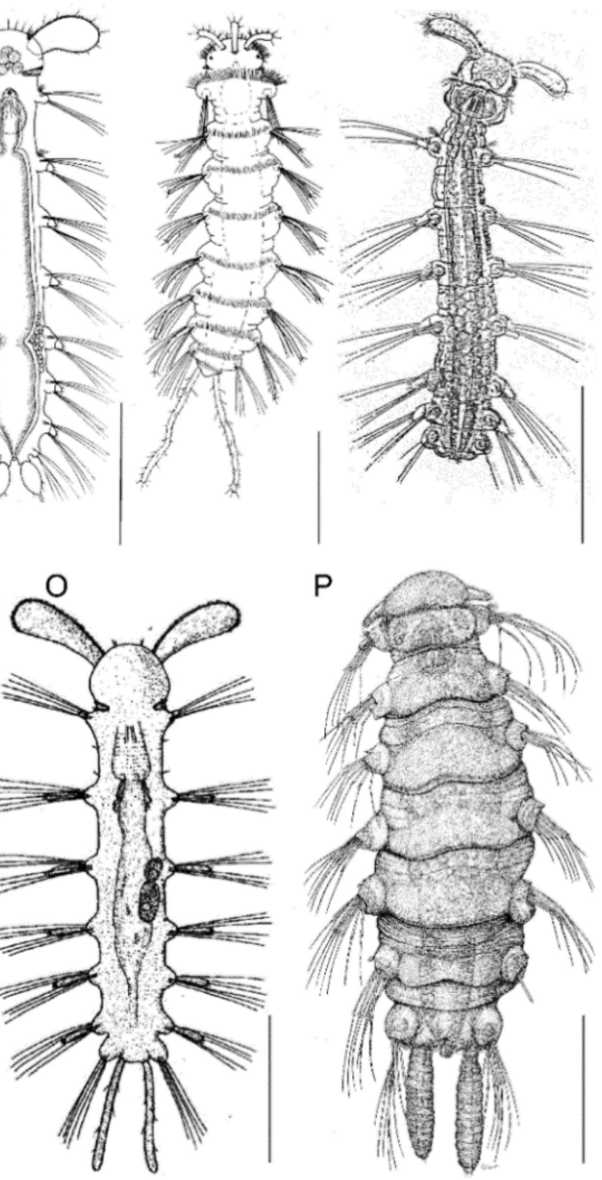

P

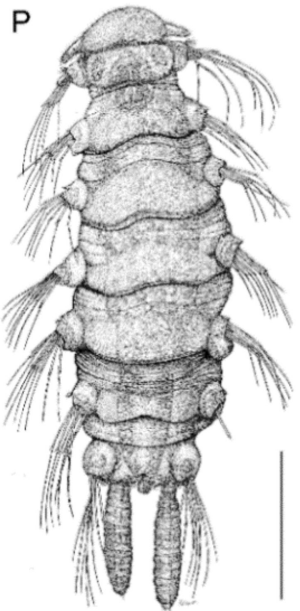

Figure 7. Schematic drawings of Nerillidae genera. (A) Nerilla antennata. (B) Meganerilla swedmarki. (C) Mesonerilla intermedia. (D) Mesonerilla biantennata. (E) Mesonerilla armoricana. (F) Leptonerilla diplocirrata. (G) Speleonerilla saltatrix. (H) Micronerilla minuta. (I) Thalassochaetus palpifoliaceus. (J) Trochonerilla mobilis. (K) Troglochaetus beranecki. (L) Nerillidium mediterraneum. (M) Nerillidopsis hyalina. (N) Aristonerilla brevis. (O) Psammoriedlia ruperti. (P) Paranerilla cilioscutata. Scale bars $200 \mu \mathrm{m}$; all dorsal view except for $\mathrm{N}$ (ventral view). Redrawn or modified from: (A,C,D,L), [129]; (B), [130], (E), [36]; (F), [127]; (G), [40]; (H,M), [53]; (I), [131]; (J), [132]; (K), [133]; (N), [134]; (O), [135]; (P), [33]—acknowledging copyright permissions granted by the publishers. 

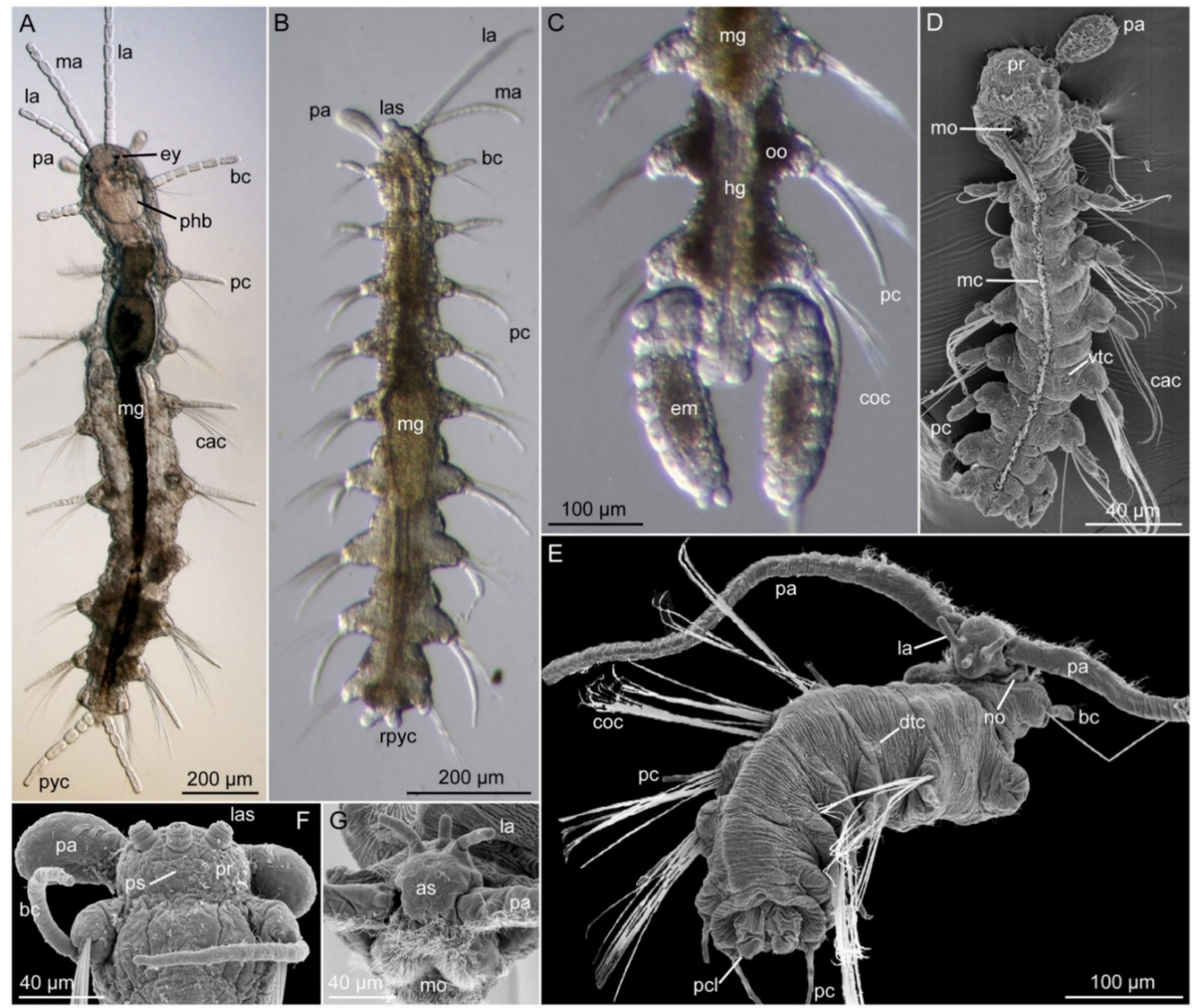

Figure 8. Morphology of Nerillidae (a-c, light micrographs; $\mathrm{d}-\mathrm{g}$, scanning electron micrographs). (A) Nerilla cf. antennata (from Roscoff, France), dorsal view (modified from [3]). (B,C). Mesonerilla cf. luederitzi (from Iriomote Island, Japan), dorsal views; entire male with sperm in posterior segments (b), posterior end of female with oocytes and embryos (c). (D). Nerillidium sp. (from Jeju Island, South Korea), ventral view. (E). Speleonerilla calypso, dorsal view (modified from [129]). (F). Leptonerilla cf. diplocirrata (from Jeju Island, South Korea), anterior end in dorsal view. (G) Speleonerilla calypso, anterior end, antero-ventral view. Abbreviations: as, anterior field of sensory cilia; bc, buccal (=segment 1) cirrus; cac, capillary chaetae; coc, compound chaetae; dtc, dorsal tuft of cilia; emb, embryo; ey, eye; hg, hindgut; la, lateral antenna; las, scar from lateral antennae; ma, median antenna; mc, midventral ciliary band; mg, midgut; mo, mouth opening; no, nuchal organ; oo, oocyte; pa, palp; pc, parapodial (interramal) cirrus; pcl, pygidial ciliated lobe; phb, pharyngeal muscular bulb; pr, prostomium; ps, posterior field of sensory cilia; pyc, pygidial cirrus; rpyc, regenerating pygidial cirrus; vtc, ventral tuft of cilia.

\subsubsection{Morphology}

Nerillids comprise a prostomium and seven to nine body segments, of which the first (buccal) segment may contain a peristomium limited to the central mouth region and a pygidium. The prostomium carries two palps (or two horns in Paranerilla), maximum three antennae and zero, two, or four eyes. The biramous parapodia possess soft outgrowths (parapodial or interramal cirri) uniquely positioned in between the dorsal and ventral bundles of capillary or compound chaetae. The pygidium likewise carries a pair of appendages, which are easily shed and lost or in a stage of regeneration upon collection. In 
Speleonerilla, the pygidium furthermore carries two heavily ciliated lobes that aid with its unique swimming locomotion [129].

A midventral ciliary band extending from the densely ciliated mouth region to the pygidium is used for gliding locomotion. In some species, this band is accompanied by additional dorsal, lateral, and ventral ciliary fields that may facilitate swimming in the water column (i.e., Trochonerilla, Speleonerilla), or burrowing in soft sediment (i.e., Paranerilla) $[34,62,136]$. Configuration and number of dorsal, lateral and ventral ciliary tufts on the palps and body is relevant for species (and sometimes genus) characterization (i.e., cilia missing, cilia/tufts distributed in one or two transverse rows per segment or dense ciliated fields) (e.g., [33,37,38,43]). In addition, presumed sensory cilia are scattered across the body and the appendages; an anterior and posterior field of sensory cilia as well as two antero-lateral bands are always present on the prostomium. Two ciliated nuchal organs are found postero-laterally of the palps, on the border of segment one $[129,137]$. Detailed mapping of the external ciliation warrants scanning electron microscopy studies on carefully fixed individuals.

During locomotion, all nerillids are capable of twisting and turning their body using their two dorsal and two ventral bundles of longitudinal muscles, which are supported by both transverse and diagonal muscles [136]. All nerillids can also perform an escape reaction, rapidly undulating their longitudinal muscles to swim a short distance. The relatively small (muscular) parapodia seemingly do not aid the swimming or gliding locomotion (hanging passively along the body) but may assist with maneuvering and attaching the chaetae within the interstitial pore spaces [129]. A ventral pharyngeal bulb muscle aids in the processing of food particles within the mouth cavity and can in some species be extended to "lick" up particles or be accompanied by a protrusible muscular "tongue" (e.g., [138-142]).

Their behavior is coordinated by a relatively elaborate nervous system, overall resembling the ganglionated, subepidermal nervous system found in most macrofaunal errantian annelids, though having a clearly separated pentaneural, ganglionated nerve cord $[61,129,143]$.

A range of glandular structures may be found, such as nuchal, pharyngeal, esophageal, parapodial, epidermal and integumental glands. Their patterns and coloration are most easily observed on live specimens in compound microscopes (with high magnification and DIC) and are occasionally used for species characterization [36,37,40].

Most nerillid species are gonochoristic and monomorphic except for organs or features related to reproduction [82]. However, some species, or genera, are found to be (simultaneously) hermaphroditic (see Table 2). Fertilization strategies may vary, but externalfertilization is generally presumed due to the absence of male genitalia, record of external sperm pouches in some species [144], and direct observation of male Nerilla antennata laying benthic spermatophores [145]. A select number of species (i.e., some Mesonerilla, Nerillidium, Nerillidopsis, and Troglochaetus) brood their offspring, attaching them to the posteriormost segments [146-151]. Nerillids are direct developers except for Paranerilla (and possibly also some species of Meganerilla), which possess a lecitotrophic benthic larvae $[53,145,149,152]$. Distribution and configuration of spermioducts holds systematic significance for genera or species groups (see Table 2) and can be observed on live specimens in high resolution light microscopy (e.g., [148,149]) or more easily with confocal microscopy of alpha-tubulin stained ciliated ducts $([42,61])$. Similar techniques can be used to map the segmented nephridia and so called enteronephridia. Whereas most genera possess protonephridia, Nerilla has metanephridia and Paranerilla has mixonephridia (e.g., [61,153] and references herein, [42]). Blind-ending enteronephridia, extending from the posteriormost midgut and lining the hind gut, are found in species-specific numbers in all examined species $[42,61,141]$. Although so far not routinely examined, their number may add valuable information to Nerillidae systematics alongside the configuration of segmental nephridia and gonoducts. 


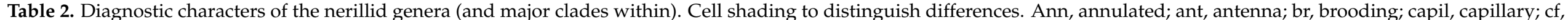

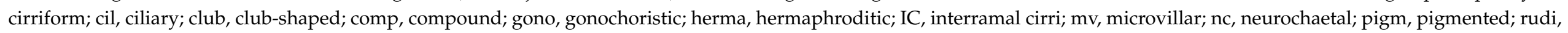
rudimental; s, shaped; segm, segment; wr, wrinkled; **, unpublished data, \#, number.

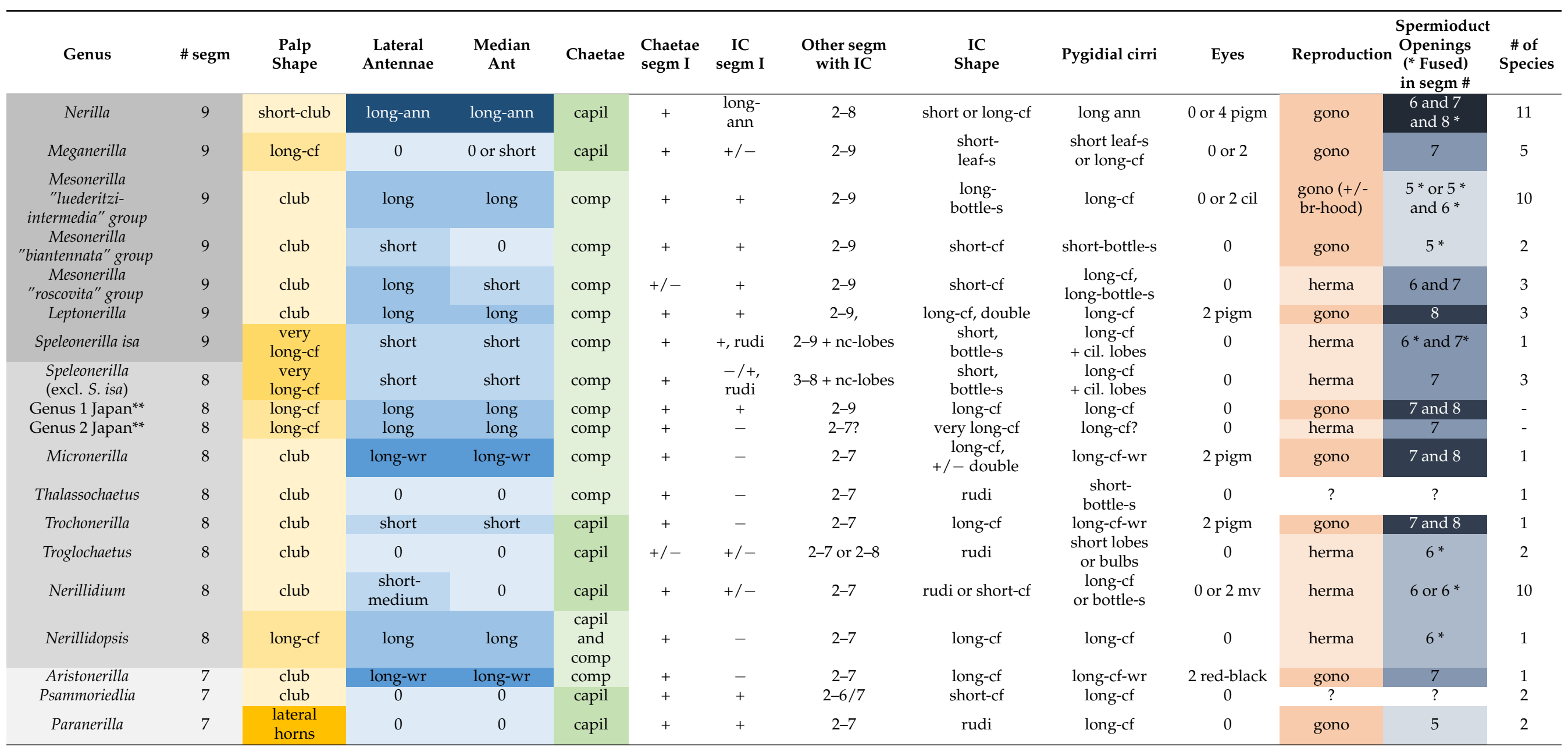




\subsubsection{Taxonomy}

Besides molecular phylogenetics, combinations of the following main morphological characteristics define the different genera: number of segments, type of chaetae, number and shape of appendages (palps, antennae, parapodial and pygidial cirri), and type of reproduction (gonochoristic or hermaphroditic), as well as number and position of spermioducts. Characteristics are provided for each genus in Table 2 (illustrated in Figure 7) and the valid species of each genus listed below. Table 2 furthermore includes data on two undescribed genera, recently found in Japan (Worsaae, Hansen et al. unpublished) as well as on three groups of Mesonerilla, two of which (M. biantenerilla-group and M. roscovita-group) are indicated in previous and ongoing analyses to represent separate genera ([42], K. Worsaae et al., unpublished).

\section{Nine-Segmented Genera}

Nerilla E. O. Schmidt, 1848 (Figure 7A)

Eleven species: Type species: Nerilla antennata E. O. Schmidt, 1848 (includes Dujardinia Quatrefages, 1866); N. rotifera (Quatrefages, 1866); N. mediterranea Schlieper, 1925; N. australis Willis, 1951; N. digitata Wieser, 1957; N. stygicola Ax, 1957; N. inopinata Gray, 1968; N. marginalis Tilzer, 1970; N. parva Schmidt and Westheide, 1977; N. jouini Saphonov and Tzetlin, 1988; N. taurica Skulari, 1997.

Meganerilla Boaden, 1961 (Figure 7B)

Five species, including synonymized Xenonerilla Müller, Bernhard and Jouin-Toulmond, 2001. Type species: Meganerilla swedmarki Boaden, 1961; M. clavata Magagnini, 1966; M. penicillicauda Riser, 1988; M. bactericola (Müller, Bernhard, and Jouin-Toulmond, 2001) (as Xenonerilla bactericola); M. cesari Worsaae, Martínez, and Núñez, 2009.

Mesonerilla Remane, 1949 (Figure 7C-E)

Fifteen species. Type species: Mesonerilla luederitzi Remane, 1949; M. intermedia Wilke, 1953; M. roscovita Lévi, 1953; M. armoricana Swedmark, 1959; M. fagei Swedmark, 1959; M. biantennata Jouin, 1963; M. pacifica Jouin, 1970; M. equadoriensis Schmidt and Westheide, 1977; M. neridae Worsaae and Rouse, 2009; M. arya, M. laerkae, M. katharinae, M. peteri, M. runae, M. xurxoi Worsaae, Mikkelsen, and Martínez, 2019.

Leptonerilla Westheide and Purschke, 1996 (Figure 7F)

Three species. Type species: Leptonerilla diplocirrata Westheide and Purschke, 1996; L. prospera (Sterrer and Iliffe, 1982) (as Mesonerilla prospera); L. diatomeophaga (Núñez, 1997 in Núñez, Ocaña, and Brito 1997) (as Mesonerilla diatomeophaga).

\section{Eight-Segmented Genera}

Speleonerilla Worsaae, Sterrer and Iliffe, 2018 (Figure 7G)

Four species. Described as Longipalpa Worsaae, Sterrer and Iliffe, 2004. Type species: Speleonerilla saltatrix (Worsaae, Sterrer, and Iliffe, 2004); S. calypso, S. isa, S. salsa Worsaae, Gonzalez, Armenteros, IIiffe, Kerbl, Holdflod, Terp, and Martínez, 2018.

Micronerilla Jouin, 1970b (Figure 7H)

Monotypic. Type species: Micronerilla minuta (Swedmark, 1959) (as Mesonerilla minuta).

Thalassochaetus Ax, 1954 (Figure 7I)

Monotypic. Type species: Thalassochaetus palpifoliaceus Ax, 1954

Trochonerilla Tzetlin and Saphonov, 1992 (Figure 7J)

Monotypic. Type species: Trochonerilla mobilis Tzetlin and Saphonov, 1992.

Troglochaetus Delachaux, 1921 (Figure 7K)

Two species. Type species: Troglochaetus beranecki Delachaux, 1921; T. simplex (Levi, 1953) (as Nerillidium simplex).

Nerillidium Remane, 1925 (Figure 7L)

Ten species, including synonymized Afronerilla Faubel, 1978, Akessoniella Tzetlin and Larionov, 1988, Bathynerilla Faubel, 1978. Type species: Nerillidium gracile Remane, 1925; N. troglochaetoides Remane, 1925; N. mediterraneum Remane, 1928; N. levetzovi Remane, 1949; N. macropharyngeum Jouin, 1970; N. renaudae Jouin, 1970; N. lothari Schmidt and Westheide, 
1977; N. marinum (Faubel, 1978) (as Bathynerilla marinum) and N. hartwigi (Faubel, 1978) (as Afronerilla hartwigi), N. orientalis (Tzetlin and Larionov, 1988) (as Akessoniella orientalis). We have here chosen to also refer Afronerilla hartwigi Faubel, 1978 to Nerillidium, since its description is obviously based on poorly preserved material, and the lack of antennae and cirri most likely reflects losses rather than diagnostic differences to Nerillidium. This synonymization does not affect the diagnosis of Nerillidium.

Nerillidopsis Jouin, 1966 (Figure 7M)

Monotypic. Type species: Nerillidopsis hyalina Jouin, 1966.

Seven-Segmented Genera

Aristonerilla Müller, 2002 (Figure 7N)

Monotypic. Type species: Aristonerilla brevis (Saphonov and Tzetlin, 1997) (as Micronerilla brevis).

Psammoriedlia Kirsteuer, 1966 (Figure 7O)

Two species. Includes synonymized Bathychaetus Faubel, 1978. Type species: Psammoriedlia ruperti Kirsteuer, 1966; P. heptapous (Faubel, 1978) (as Bathychaetus heptapous). Descriptions based on poor material possibly most likely having lost antennae and cirri and B. heptapous possibly even representing Nerillidium juveniles (with seven instead of eight segments).

Paranerilla Jouin and Swedmark, 1965 (Figure 7P)

Two species. Type species: Paranerilla limicola Jouin and Swedmark, 1965; P. cilioscutata Worsaae, and Kristensen, 2003.

\subsubsection{Distribution and Diversity}

Nerillidae is represented in all oceans across a large diversity of habitats, including brackish open waters, anchialine caves, and fresh groundwater habitats ([32] and references herein). Troglochaetus beranecki is found in (primarily subterranean) limnic and hyporheic environments of Europe and USA (e.g., [133,154-156]). Nerillid depth distribution ranges from the deep sea to shallow coastal waters, with the greatest diversity seen in fully marine, well-oxygenated, sandy to gravelly sediment (e.g., [27,32,36,129] and references herein).

The more species-rich genera Mesonerilla, Meganerilla, Nerilla, and Nerillidium are found worldwide [32]. In contrast, Paranerilla prefers colder Atlantic waters [33,152], and Leptonerilla, Psammoriedlia, Speleonerilla, and Trochonerilla have more often been recorded in warmer waters. Most geographical regions outside Europe and the US East Coast as well as deeper waters worldwide are generally undersampled. Further sampling is necessary to predict a possible geographical delimitation of some of these warm-water genera as well as of the more geographically restricted Micronerilla, Aristonerilla, Thalassochaetus, Nerillidopsis and Troglochaetus.

Nerillids lack a pelagic larval stage (except for species of Paranerilla) and any other dispersal stages. Molecular studies have revealed new (sometimes cryptic) species within relatively short geographical distances (e.g., among Caribbean islands; [37,42,45]). In fact, every new meiofaunal survey on sandy sediment in coastal tropical and sub-tropical regions has revealed undescribed nerillids. The species diversity of Nerillidae is therefore expected to multiply, raising with every taxonomic study in previously uninvestigated regions. The species number has already increased drastically over the last two decades despite the limited number of taxonomists working with this group. However, since the morphological disparity of new species is often limited, potential morphological apomorphies can only be documented through time consuming and detailed microscopical examinations. Moreover, any taxonomic studies should be accompanied by molecular sequences to ensure the future identification of cryptic species. In some cases, molecular taxonomy is the only or the fastest way forward [37,157], yet the cryptic diversity may only be fully unraveled by likewise challenging, extensive population genetic studies [38].

Surprisingly, new genera or species with highly diverging morphology have in recent decades only been found in highly diverging environments such as anchialine caves or 
the deep sea ([39,40], K. Worsaae, unpublished). The worldwide distribution of several genera and the lack of discoveries of new genera in "similar-type" shallow sandy sediments point to an old origin of the family as is also predicted from more recent and ongoing phylogenomic analyses ([13]; K. Halanych, G. Rouse, pers comm.).

\subsubsection{Major Revisions and Most Important Literature}

Multiple studies have addressed the diversity and systematics of nerillids, but some of the most recent and larger revisions include Müller et al. [39], Müller [134], Worsaae and Müller [61], Worsaae [3,32,42,129,158], Westheide [53], Worsaae et al. [37], as well as two ongoing phylogenetic studies (K. Worsaae et al., unpublished).

\subsection{Polygordiidae Czerniavsky, 1881}

\subsubsection{Phylogenetic Affinities}

Polygordiidae contains the genus Polygordius, with 18 described species and two subspecies [48]. Polygordius species are remarkable in their body simplicity, lacking parapodia and chaetae. Due to this lack of typical annelid characters, they were considered by early authors as a primitive form, closely resembling the common ancestor of Annelida [6]. Due to this, the genus Polygordius holds a tremendous historical importance towards the early theoretical studies on the evolution of Metazoa and Annelida, dating back to 1843. The early life stages of Polygordius were described prior to the adults. The endolarva was described by Lovèn [159], highlighting their dramatic metamorphosis. Agassiz [160] described the development and metamorphosis of the larva from the western Atlantic, being similar to Lovèn's. Schneider [161] found them so unique that he created an order for them, the Gymnotoma. Two years later, Schneider [162] described Polygordius adults from the west coast of Helgoland and the development of the larvae from an undescribed species from the Mediterranean. Finally, Hatschek [6] studied the larval development of Polygordius, describing it as the most primitive annelid genus, nearest to the generalized stem of the annelids. In his study, Hatschek also proposed the great phylogenetic significance of the trochophore larva, where groups possessing this larval type had evolved from a common stem form, the "Trochozoan." The "Trochophore Theory" gained wide acceptance and Polygordius, with its supposedly primitive anatomy and its highly developed trochophore larva, was regarded as the most primitive annelid (for a detailed historical description, see [5]).

Nowadays, the simplicity of Polygordius is interpreted as secondary, having evolved as an adaptation to life in interstitial habitats. The family is closely related to Protodrilida [11] or Phyllodocida [10] as part of Errantia. A molecular and morphological phylogeny of the family focusing on species from European Atlantic regions recovered six valid species: Polygordius appendiculatus; P. lacteus; P. neapolitanus; P. triestinus; P. jouinae; and P. eschaturus. Both $P$. erythrophthalmus and $P$. villoti are considered as invalid species, synonymous with $P$. lacteus [163]. After the first molecular phylogeny of the genus, Tustison et al. [47] described four new species by including data from the Pacific and Caribbean, increasing the number to the now 18 valid species $[47,164]$.

\subsubsection{Morphology}

Polygordiidae have a thin, slender body, which is cylindrical in cross-section with shallow ventral and ventro-lateral grooves along the body in certain species (length 10-100 mm; width $<1 \mathrm{~mm}$ ). Trunk segments are poorly delineated externally and the animals are characterized by an iridescent cuticle that resembles that of nematodes in their appearance due to the smooth body surface. The cuticle is comparatively thick and formed by several stacked layers of prominent collagen fibers arranged in parallel within a fine fibrillar matrix, giving way to the iridescent appearance [24]. Unlike many interstitial annelid species, external ciliation is usually absent, except for $P$. jouinae, which has a ciliated pygidium [165]. Parapodia and chaetae are absent. 
The prostomium is rounded or conical with frontally orientated paired palps (Figure 9A,B) [166]. The homology of these appendages with palps has been long debated (see $[167,168])$. However, studies using transmission electron microscopy (TEM) have shown the same innervation patterns as palps in other annelids [166]. The palps are relatively rigid and lacks ciliation, vessels, coelomic cavities and musculature, and thus they have been interpreted as purely sensoric and not involved in feeding [164]. Pigmented eyes are absent, but unpigmented rhabdomeric and ciliary receptor cells might be present in front of the brain [166]. Red pigment spots are present in the prostomium of $P$. lacteus [164].
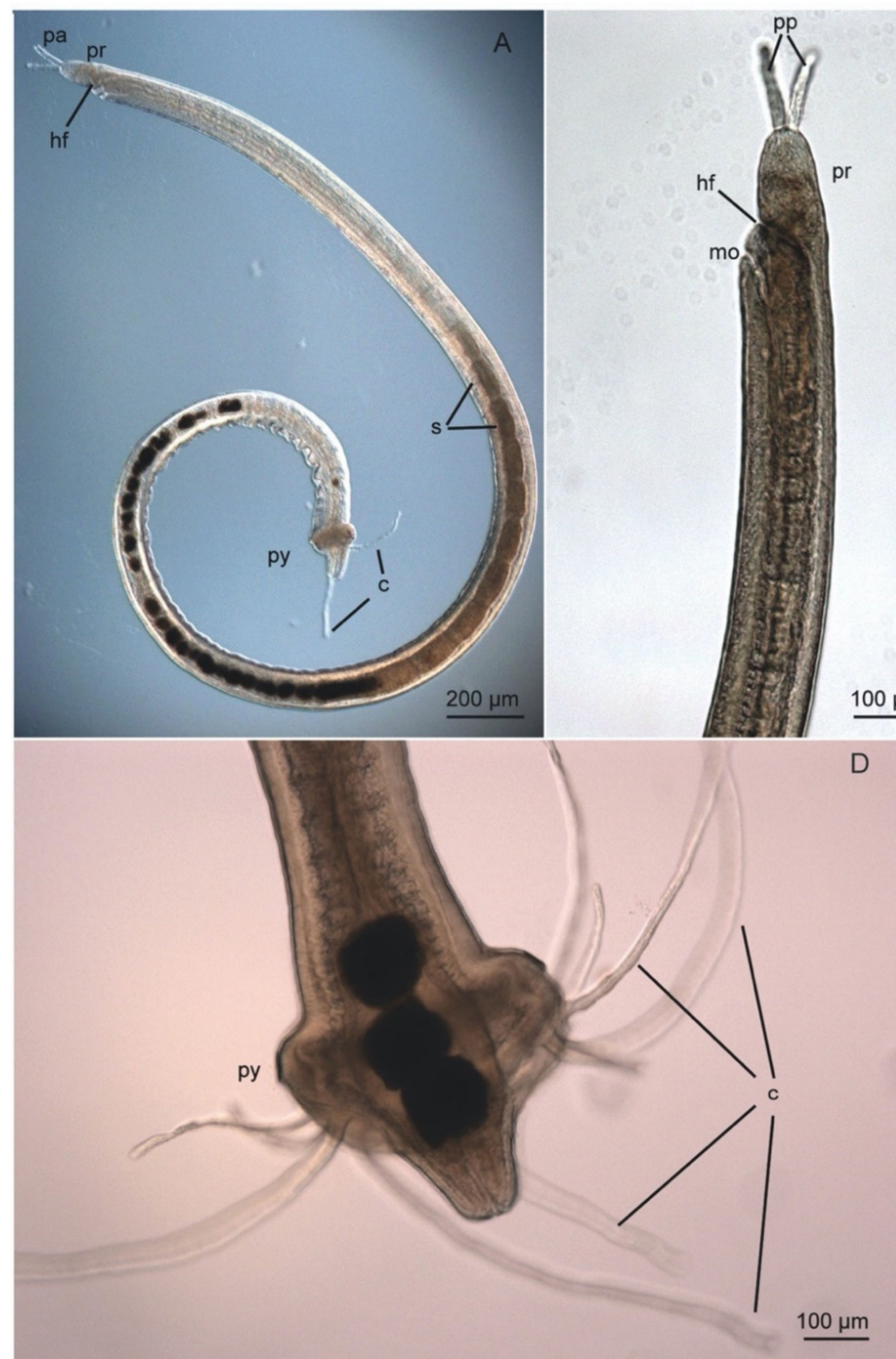

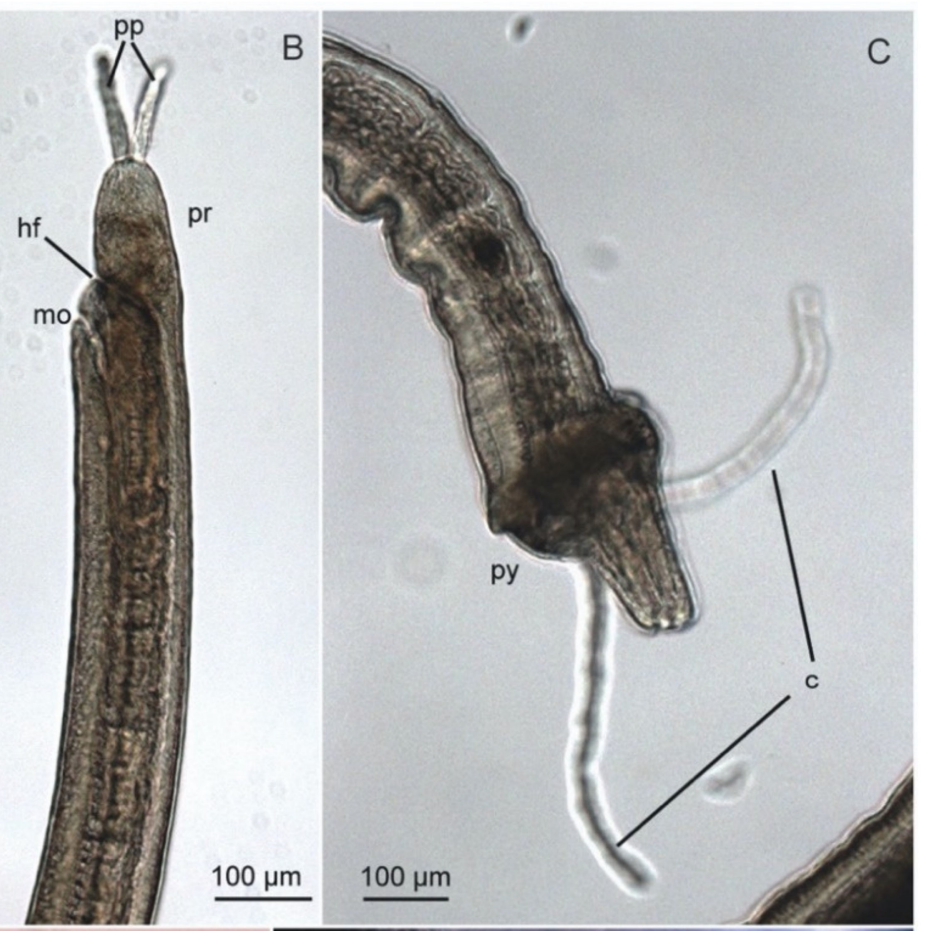

D

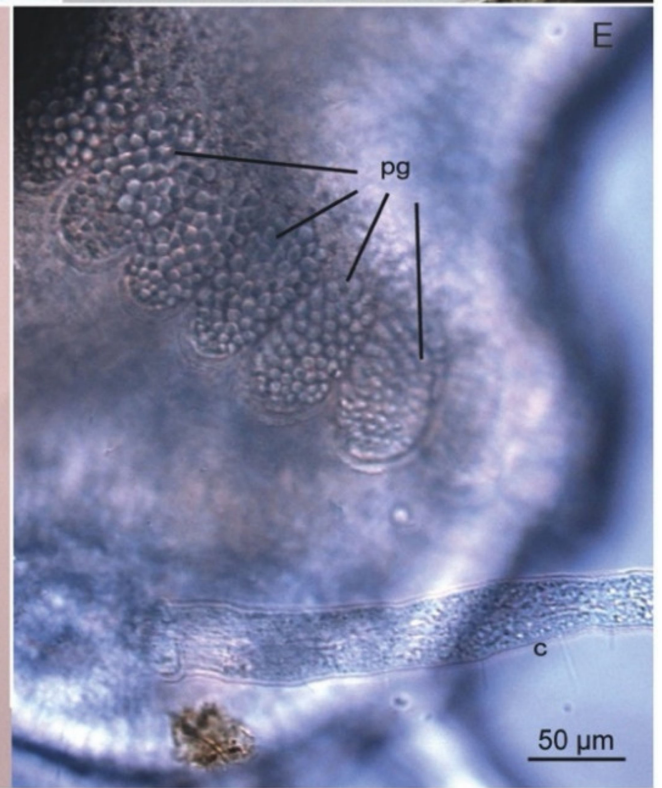

Figure 9. Morphology of Polygordius. (A-C) Polygordius sp. (São Sebastião Island, São Paulo, Brazil). (A) Entire body. (B) Anterior end. (C) Posterior end. (D,E) Polygordius leo (São Sebastião Island, São Paulo, Brazil). (D) Details of pygidium (E) Adhesive pygidial glands. Abbreviations: c, cirrus; hf, head fold; mo, mounth opening; pa, palps; pg, pygidial glands; pp, paired palps, pr, prostomium; py, pygidial lobe; s, segment. muscular bulb. 
The peristomium is separated from the prostomium by the head fold, which raises in front of the ventral, slit-shaped mouth (Figure 9A,B [168]). The nuchal organs are oval and densely ciliated, extending dorso-laterally between the prostomium and the peristomium [137].

The trunk consists of 200 or more segments, followed by a pygidium that may be inflated or cylindrical depending on the species. The pygidium may be encircled by adhesive pygidial glands [169] that vary in size, shape, and number depending on the species (Figure 9E, [168]). Pygidial cirri may also be present, either terminally or subterminally, forming distinctive anal lobes at the tip of the pygidium.

The musculature of Polygordius resembles other interstitial annelids and is arranged in four groups of longitudinal fibers, numerous segmentally arranged oblique muscles and weakly developed circular fibers. The gut is a straight tube. The mouth cavity presents prominent densely ciliated protrudable dorsolateral folds, which continue into the pharynx, also containing a ventral pharyngeal sac directly posterior to the mouth. The pharynx opens dorsally into the esophagus, followed by the foregut with a characteristic ventral ridge carrying longer cilia. The lower epithelium of the hindgut comprises longitudinal folds and lacks glands. Coelomic cavities, mesenteries, and muscular septa are well developed throughout the trunk. The circulatory system is closed and well-developed. Excretory organs are segmentally arranged metanephridia; the first pair formed by fusion of the second pair of larval protonephridia with the first pair of metanephridia. Sexes are separated and sexual products occur in a variable number of fertile segments. The spermatozoa are typically of the ecto-aquasperm type (sense [170]), while oocytes are relatively small and occur in large numbers, completely filling the coelom of sexually mature females. Sexual products are probably released by rupture of the body wall, since no genital ducts are present.

\subsubsection{Taxonomy}

Identifying Polygordius species based on morphological characters alone can be challenging. Their long cylindrical bodies appear relatively similar to one another under visual inspection, and the distinguishing features useful for morphology-based discrimination of species are small, requiring examination with scanning electron microscopy (SEM) [48,164]. The list of the 18 valid species and the two subspecies is listed below.

Polygordius Schneider, 1868

Eighteen species, two subspecies: Type species, Polygordius lacteus Schneider, 1868; P. appendiculatus Fraipont, 1887; P. antarcticus Rota and Carchini, 1999; P. arafura Avery, Ramey and Wilson, 2009; P. erikae Tustison, Ramey-Balci and Rouse, 2020; P. eschaturus Du Bois-Reymond Marcus, 1948; P. eschaturus brevipapillosus Jouin and Rao, 1987; P. ijimai Izuka, 1903; P. jouinae Ramey, Fiege and Leander, 2006; P. kiarama Avery, Ramey and Wilson, 2009; P. kurthcarolae Tustison, Ramey-Balci and Rouse, 2020; P. kurthsusanae Tustison, RameyBalci and Rouse, 2020; P. jenniferae Tustison, Ramey-Balci and Rouse, 2020; P. leo Du Bois-Reymond Marcus, 1955 (Figure 9D,E); P. madrasensis Aiyar and Alikunhi, 1944; P. neapolitanus Fraipont, 1887; P. pacificus Uchida, 1935; P. pacificus floreanensis Schmidt and Westheide, 1977; P. triestinus Hempelmann, 1906; P. triestinus sensu Jouin, 1970; P. uroviridis Aiyar and Alikunhi, 1944.

\subsubsection{Distribution and Diversity}

Polygordiidae are often included as part of the meiofaunal or interstitial annelid literature because they spend their life living interstitially among the coarse sand grains. However, their size makes them part of the macrofaunal community as it is usually defined as organisms retained on a $500 \mu \mathrm{m}$ mesh sieve [171]. Although they occur in several interstitial habitats, they have a strong affinity for highly energetic systems with coarse sediments $[172,173]$. They are found worldwide in intertidal, shallow subtidal, and also in continental slope sediments at depths between 1000 and $5000 \mathrm{~m}$ in Antarctic waters [164]. The limited knowledge on the behavior, feeding strategies, and general ecology of Poly- 
gordiidae comes from studies of $P$. jouinae from the inner continental shelf off of New Jersey, USA $[14,172,173]$.

A recent molecular phylogeny illustrated the lack of a clear biogeographic pattern for the genus [47]. The Atlantic, European and Mediterranean terminals were placed in three regions of the tree and none were close to the Caribbean P. jenniferae, which showed a low COI divergence from Polygordius sp. from California. The Australian/French Polynesian species did form a discrete clade [47].

\subsubsection{Major Revisions and Most Important Literature}

Distribution patterns of the described species of Polygordiidae were first summarized in Rota and Carchini [170], but more recently, a large effort integrating morphology and molecular data is presented by $[47,163,164]$.

\subsection{Protodrilidae Hatschek, 1888}

\subsubsection{Phylogenetic Affinities}

Protodrilidae contains six valid genera with 38 described species ranging in size from 1 to $13 \mathrm{~mm}$ and comprising up to 60 segments [174]. The presence of non-grooved ventral filiform palps with internal canals and the possession of a bilobed adhesive pygidium support their relationship to Saccocirridae and Protodriloididae. These three families are often recovered together in molecular analyses, even when few markers are employed [175]. However, due to their comparatively simple external morphology across all members of these three families, their phylogenetic position within Annelida shifted historically, from the basally branching clade "Archiannelida" (subsequently shown as polyphyletic) to the currently derived position as a sister clade of Errantia [10,11].

The names Protodrilidae and Protodrilus, which refer to this external simplicity, were first introduced by Czerniavsky [176] to accommodate Protodrilus mirabilis. However, since his short description is largely incomplete and lacks supporting type material, P. mirabilis is today considered an invalid species and Protodrilidae sensu Czerniavsky [176] is nomen dubium. Therefore, the genus Protodrilus was first erected by Hatschek (1881) to name the species Protodrilus leuckartii from a coastal lagoon in Sicily, Italy [177]. The same author afterwards erected Protodrilidae to accommodate this species [178], as well as Lindrilus flavocapitatus, originally described as a Polygordius species [179].

Protodrilidae sensu Hatschek, 1888 traditionally consisted of the genera Protodrilus (36 species), Astomus (one species), and Protodriloides (two species) [50]. However, Protodrilus was originally diagnosed based on plesiomorphic characters, as highlighted by cladistic analyses that first motivated the transfer of Protodriloides into a separate family (see section on Protodriloididae), and later, the systematic rearrangement of Protodrilus [50,180]. This last systematic rearrangement involved the re-description of Protodrilus and Astomus, and the description of four new genera consistent with each of the major monophyletic clades recovered in these analyses. Protodrilidae is currently divided into six genera, with Lindrilus and Protodrilus branching off as a sister to the clade including (1) Astomus and Megadrilus, and (2) Meiodrilus and Claudrilus [173,174] (Figure 10). Anecdotally, Lam [181] introduced a monotypic protodrilid genus for the species Protannelis meyeri Lam, 1922, currently considered as invalid, as it was described from a single, fragmented specimen lacking any of the typical protodrilid features.

\subsubsection{Morphology}

The external morphology of Protodrilidae is rather simple. The prostomium, generally rounded, is followed by a comparatively large peristomium (Figure 11A-E), a long cylindrical trunk lacking chaetae and parapodia (Figure 10G,L), and a bilobed adhesive pygidium (Figure 11N) [50]. The most conspicuous external characteristics are the paired filiform palps that arise anteroventrally from the prostomium and are provided with an internal coelomic channel connected behind the brain (Figure 10A,F) [180]. Exceptionally, Astomus taenioides has a characteristically festooned trunk (Figure 10F) [182,183], while the 
cave-exclusive Megadrilus pelagicus bears a dorsal keel which aides their stabilization while drifting in the water column of flooded lava tubes [41]. Although the family is almost exclusively interstitial, its members can barely be considered meiofaunal. In fact, the plesiomorphic state for the body size in Protodrilidae is rather large, decreasing evolutionarily in the lineages corresponding to the genera Astomus, Claudrilus and Meiodrilus [50]. This has been interpreted as an adaptation to the epidermal uptake of nutrients in Astomus (i.e., as it reduced the ratio between body surface and volume) and a consequence of a more specialized lifestyle in Claudrilus_-Meiodrilus. In fact, species of Claudrilus and Meiodrilus often have shorter palps and are provided with segmentally arranged adhesive glands, which might facilitate squeezing through the tight interstitial spaces while providing additional attachment points in this genuinely turbulent environment [184].

In order to explore the interstitial spaces, all protodrilids glide by means of their midventral motile ciliary band, which consists of four to five rows of multiciliate cells arranged along a shallow groove [185]. If other ciliary bands are present, they are typically sensory or involved in the production of water currents $[28,174]$. The latter can be found on the head or arranged segmentally on the trunk, in both cases holding important systematic value. Megadrilus pelagicus uses ciliary bands to drift in the water column of anchialine caves [41]. The adhesive pygidium also plays a role in locomotion $[184,186]$, both by providing attachment to the substrate and by facilitating changes in direction or fast retraction of the body in combination with trunk musculature.

The presence of a conspicuous ventral pharynx occupying the posterior half of the peristomium is another distinctive feature of Protodrilidae (Figure 11A). This structure is probably optimized for grazing on the biofilms and as well as for collecting and grating different types of deposited organic particles at low Reynolds numbers [174]. The pharynx consists of a prominent ventral muscular bulb formed by transverse muscular fibers and a few interstitial cells and surrounded by the sagittal muscle, which attaches dorsally to the so-called tongue-like organ [187], despite the structure having nothing to do with the tongue as described in vertebrates, but rather resembles the radula, as described in many gastropod molluscs. This organ is situated in the dorsoposterior part of the buccal cavity between the muscular bulb and the esophagus and bears a thick cuticular plate that is likely involved with grating and dislodging food particles [188]. The pharyngeal apparatus is vividly red in species of Lindrilus and Megadrilus, as well as in Protodrilus ciliates, while it retains dark pigmentation in Claudrilus helgolandicus and C. hypoleucus $[49,174,189]$. Segmentally arranged salivary glands extend from the pharynx to the posterior end of the body, often in a species-specific number of segments [190].

The presence of different types of sensory organs is another useful diagnostic feature in Protodrilidae. Ventral pigmented eyes characterize the genus Lindrilus (Figures 10A and 11A), whereas dorsal pigmented eyes are only found in adults of Protodrilus oculifer (Figure 10B). Large, rounded, unpigmented ciliary receptors are a synapomorphy of the clade LindrilusProtodrilus and are retained in all described species (Figures 10A-C and 11F), while smaller, oval phaosomal receptors are more common in Meiodrilus and Claudrilus (Figure 11G) [20]. No light-sensitive sensory structures are present in Megadrilus; however, they bear large nuchal organs that extend as transverse ciliated furrows on both sides of the prostomium (Figure 10D) [49]. 


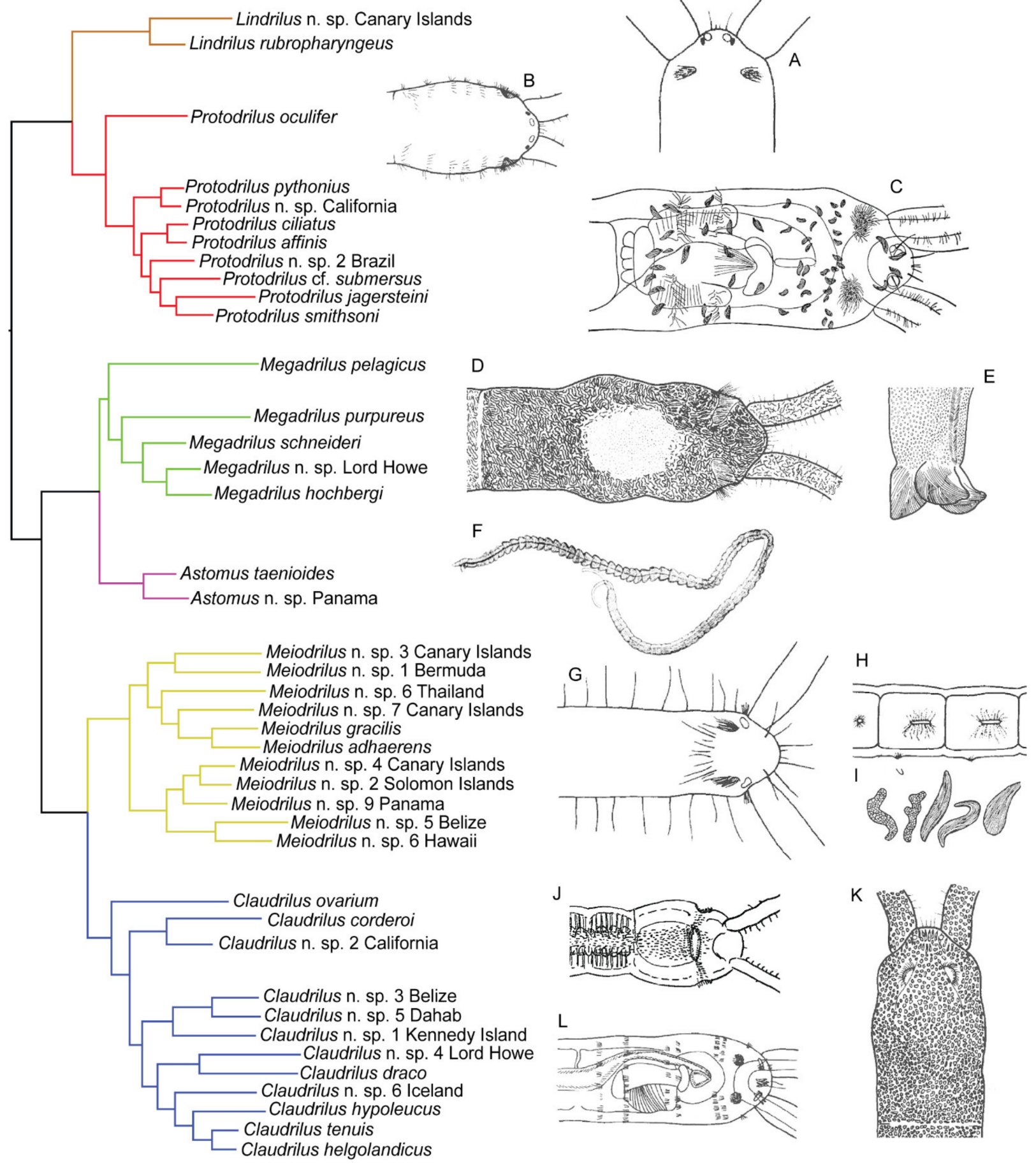

Figure 10. Diagram showing the phylogenetic relationships of Protodrilidae based on four molecular markers (18S rRNA, 28 rRNA, COI, H3) and morphology analyzed with maximum likelihood methods (Redrawn from [50], along with illustrations representing the diagnostic characters for each genus. (A) Lindrilus rubropharyngeus, anterior end showing the presence of eyes, ciliated organs and the shape of the nuchal organs (B) Protodrilus oculifer, anterior end showing the presence of eyes and ciliated unpigmented organs. (C) Protodrilus albicans, anterior end. (D) Megadrilus purpureus, anterior end. (E) Megadrilus purpureus and its characteristic trilobed pygidium. (F) Astomus taenioides, showing the festooned trunk segments. (G) Meiodrilus adhaerens, anterior end. (H) Meiodrilus adhaerens, lateral organs. (I) M. adhaerens, cocoon glands. (J) Claudrilus corderoi, anterior end. (K) Claudrilus hypoleucus, anterior end showing the epidermal glads. (L) Claudrilus hypoleucus, anterior end. A, redrawn from [191]; (C,L), redrawn from [28], (D,K), from [53]; (F), from [31], (B,G-I), from [192], (J) from [108]. 

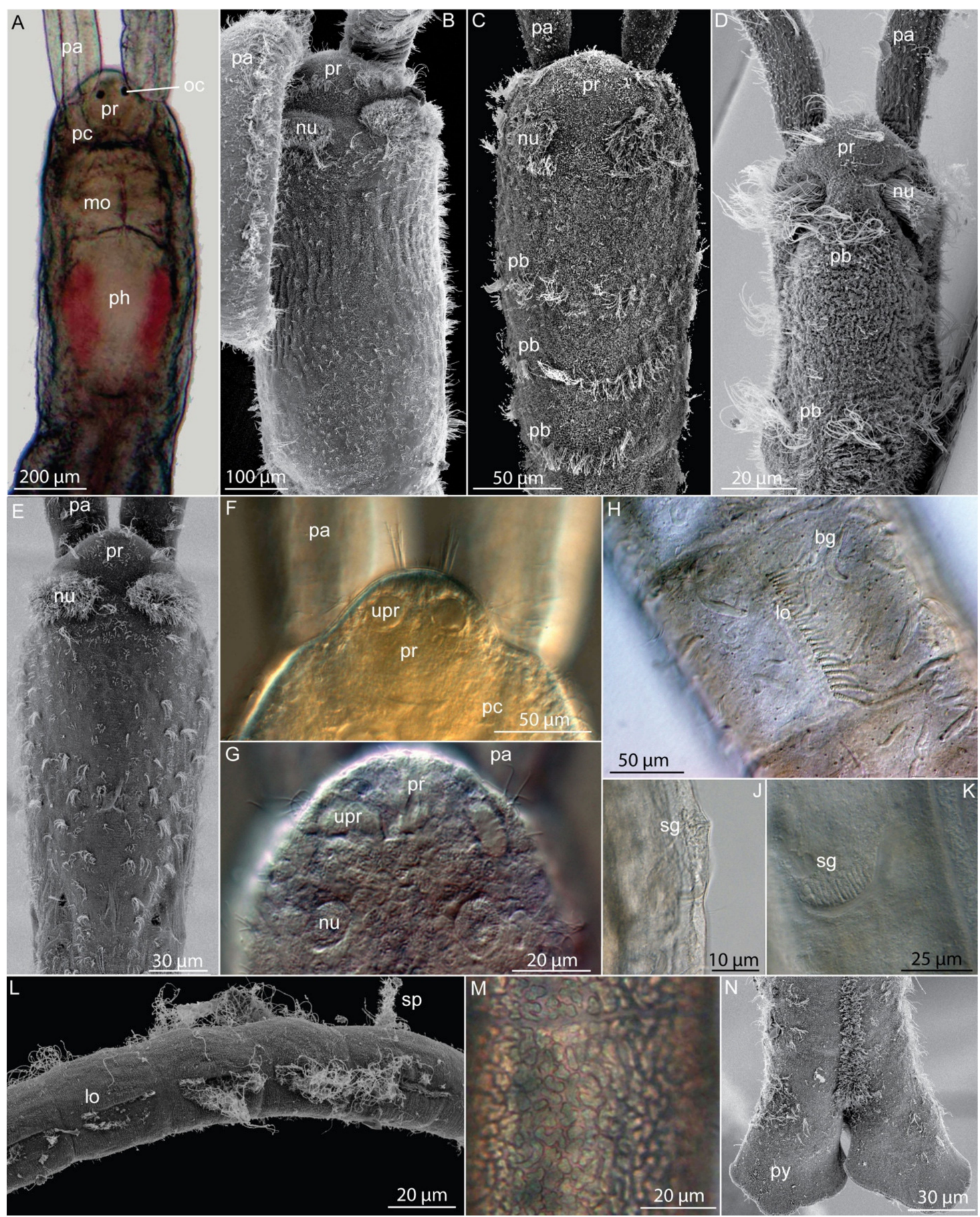

Figure 11. Morphology of Protodrilidae. (A,F,N) Lindrilus sp. (La Palma, Canary Islands). (B) Megadrilus schneideri (Capo Caccia, Sardegna, Italy). (C,M) Claudrilus cf. hipoleucus (Tenerife, Canary Islands). (D) Meiodrilus sp. (Phuket, Thailand). (E) Protodrilus smithsoni (Bocas del Toro, Panama). (G) Claudrilus hypoleucus (La Maddalena, Sardegna, Italy). (H,J,K) Meiodrilus adhaerens (Svinbaden, Helsingør, Denmark). (L) Claudrilus ovarium (Parana, Brasil). (A) Light micrographs of the anterior region. (B-E) Scanning electron micrographs of the anterior region. (F-G) Light micrographs of the prostomium showing different types of photoreceptors. (H-K) Light micrographs of the trunk segments showing adhesive and bacillary glands. (L) Scanning electron micrograph of the lateral organs and sperm cells. (M) Light micrograph of a trunk segment showing the epidermal glands. (N) Scanning electron micrograph of the pygidium. Abbreviations: bg, bacillary gland; lo, lateral organs; nu, nuchal organ; oc, ocelli; pa, palps; pb, prostomial ciliary band; pc, palp canal; ph, pharynx; pr, prostomium; mo, mouth; py, pygidium; sg, segmental adhesive glands; sp, sperm cells; upr, unpigmented prostomial receptor. All images reproduced with permission from [174]. 
All Protodrilidae are gonochoristic and have a fixed number of fertile trunk segments, using the coelomic cavity to store spermatids, spermatozoa, or oocytes [28]. There are two types of slender and filiform spermatozoa in males, the euspermatozoa, which are involved in the fertilization of the oocytes, and the paraspermatozoa, which play a role in the enzymatic opening of the spermatophore and the female epidermis during sperm transfer [193]. While the ultrastructure of sperm might hold phylogenetic information at the genus level, it seems too conserved to diagnose species. Similarly, the size and abundance of oocytes in females are useful characteristics to identify the different genera [174]. Externally, all protodrilid males present lateral organs in the anterior part of the body (Figure 11L) [194], consisting of paired invaginations of the epidermis that form a wide furrow into which numerous gland cells open and cilia project [193]. Lateral organs are involved in the production of the spermatophore and generally appear on a species-specific number of anterior segments. Therefore, the number, position and morphology of the lateral organs have been traditionally used as the main characteristics for species delineation $[174,186]$. The posteriormost pairs of lateral organs are associated with a specific number of gonoducts, which is generally conserved within each genus and therefore useful in their diagnoses and identification [194]. Females, in contrast, generally lack any conspicuous external reproductive structures. Exceptions include dorsal organs described in Lindrilus rubropharyngeus and L. flavocapitatus, consisting of segmentally arranged rosette-like structures extending backwards from segments 19-22, and the ciliary furrows described in Protodrilus leuckartii and P. ciliatus, consisting of a long structure similar to the lateral organs of males [195]. Both of these structures are involved in sperm transfer. Oviducts are described only in a few species (see $[28,194])$.

\subsubsection{Taxonomy}

The following main morphological features (in various combinations) define the different genera: length of the body, pharyngeal pigmentation, number and shape of prostomial sensory organs (ciliated receptors, phaosomal receptors, pigmented eyes, nuchal organs), extension of the salivary glands, external ciliary patterns (number of transverse bands on the head and trunk) as well as number and position of male lateral organs.

Protodrilus Hatschek, 1881

Diagnosis: Body opaque white. Prostomium with ciliated palps, with or without pigmented eyes and with rounded, unpigmented ciliary receptors. Nuchal organs oval, extending dorsolaterally between the prostomium and peristomium. Salivary glands of variable length, normally from segments 1 to $5-15$. Two pygidial lobes. Males with continuous or segmented lateral organs and three to four pairs of spermioducts; females without oviducts and about ten small oocytes per segment.

Fifteen species: Type species: Protodrilus leuckartii Hatschek, 1880; P. hatscheki Pierantoni, 1908; P. oculifer Pierantoni, 1908; P. ciliatus Jägersten, 1952; P. robustus Jägersten, 1952; P. albicans Jouin, 1970; P. brevis Jouin, 1970; P. infundibuliformis Schmidt and Westheide, 1977; P. huanghaiensis $\mathrm{Wu}$, Sun, and Chen, 1980; P. jagersteni von Nordheim, 1989; P. litoralis von Nordheim, 1989; P. submersus von Nordheim, 1989; P. gelderi Riser, 1997; P. pythonius Di Domenico, Martínez, Lana, and Worsaae, 2013; P. smithsoni Martínez, Di Domenico, Jörger, Norenburg, and Worsaae, 2013.

Astomus Jouin, 1979

Diagnosis: Body whitish, with festooned segments. Prostomium with ciliated palps, unpigmented receptors present, but no pigmented eyes. Nuchal organs rounded dorsal, positioned dorsally on the prostomium. Mouth and pharyngeal organ absent; ciliated gut residual all along the body, comprising few ciliated cells with large vacuoles containing sphaerocrystals. Salivary glands reduced. Two pygidial lobes. Males with lateral organs on segments 13-22 that extend over two consecutive segments and with two short ciliated grooves on segments 9-10; one pair of spermioducts in segment 17.

Monotypic: Astomus taenioides Jouin, 1979, but at least two undescribed species are known [50]. 
Lindrilus Martínez, Di Domenico, Rouse and Worsaae, 2015

Diagnosis. Body large and pigmented, pharynx red. Prostomium with long ciliated palps, pigmented eyes and rounded, large, and medial unpigmented receptors. Nuchal organs dorsolateral and rounded. Salivary glands extending further than segment 15 . Two pygidial lobes. Lateral organs in males segmented and equal in size, connected to one pair of spermioducts; females with oviducts and abundant, small oocytes in each segment; dorsal organs in two species.

Three species: Type species: Lindrilus rubropharyngeus (Jägersten, 1940); L. flavocapitatus (Uljanin, 1877); L. haurakiensis (von Nordheim, 1989).

Megadrilus Martínez, Di Domenico, Rouse and Worsaae, 2014

Diagnosis: Body large and pigmented, pharynx reddish; prostomium with long ciliated palps, no eyes, small and rounded unpigmented receptors, sometimes absent. Nuchal organs long and transversely oriented between the prostomium and peristomium. Three pygidial lobes. Males with lateral organs from segment six, first lateral organ rounded and smaller; females with oviducts and abundant, small oocytes in each segment.

Four species: Type species: Megadrilus purpureus (Schneider, 1868); M. schneideri (Langerhans, 1880); M. hochbergi (Martínez, Di Domenico, Jörger, Norenburg and Worsaae, 2013); M. pelagicus (Martínez, Kvindebjerg, Iliffe and Worsaae, 2017).

Meiodrilus Martínez, Di Domenico, Rouse and Worsaae, 2015

Diagnosis: Body short and translucent, pharynx unpigmented. Prostomium with short and poorly ciliated palps. Eyes absent, but oval lateral unpigmented receptor present in most species. Nuchal organs rounded and dorsal. Salivary glands in segments 1-5, paired segmented adhesive glands ventrally on trunk segments. Two pygidial lobes. Males with continuous or segmented lateral organs; females with cocoon glands and a few comparatively large oocytes in each segment.

Four species: Type species: Meiodrilus adhaerens (Jägersten, 1952); M. indicus (Aiyar and Alikhuni, 1943); M. gracilis (von Nordheim, 1989); M. jouinae (von Nordheim, 1989).

Claudrilus Martínez, Di Domenico, Rouse and Worsaae, 2015

Diagnosis: Body whitish, pharynx unpigmented or grayish. Prostomium with palps, sometimes with motile cilia; no eyes; paired, oval, unpigmented ciliary receptors present laterally in most species. Nuchal organs dorsal and rounded, or indistinct. Salivary glands at least from segment 1 to 8 but may extend to segment 20. Epidermis sometimes with abundant glasslike vacuolar glands. Two pygidial lobes. Lateral organs variable across species; females with a few large oocytes per segment.

Ten species: Type species: Claudrilus hypoleucus (Armenante, 1903); C. pierantonii (Aiyar and Alikunhi, 1944); C. corderoi (du Bois-Reymond Marcus, 1948); C. flabelliger (Wieser, 1957); C. minutus (Kirsteuer, 1966); C. similis (Jouin, 1970c); C. tenuis (Jouin, 1970c); C. helgolandicus (von Nordheim, 1983); C. draco (Martínez, Di Domenico, Jörger, Norenburg and Worsaae, 2013); C. ovarium (Di Domenico, Martínez, Lana and Worsaae, 2013).

\subsubsection{Distribution and Diversity}

Protodrilids are known from all over the world, except for the Antarctic [174]. All genera are cosmopolitan, with the exception of Astomus, which seems to exclusively live in organic-matter rich sediments associated with Pacific coral reefs [196]. A few species of protodrilids are known from a single locality, whereas those described with wide distribution ranges may represent cryptic or pseudocryptic species $[28,196,197]$. Certain groups of species seem to be restricted to Europe (e.g., Claudrilus hypoleucus and C. helgolandicus, Protodrilus ciliatus and P. affinis), or represent clades with a Western Atlantic-Indopacific distribution (e.g., Protodrilus jagersteni, P. smithsoni, and P. submersus) [50]. However, these patterns are likely to be spurious and arise from poor species identification combined with a geographically biased sampling effort rather than accurately reflecting the real distribution of the group [174].

In regard to habitats, protodrilids are mostly recorded from shallow water marine sediments, where they prefer coarse, well-sorted sands between 0 and $10 \mathrm{~m}$ depth [14]. 
Records below $50 \mathrm{~m}$ depth are rare [30]. Protodrilus spongioides was once recorded from freshwater sediments at the Anton Dohrn Marine Station in Italy [198], although the rather scarce description raises doubts about the validity of this taxon. Other protodrilids exhibit a more or less loose preference for certain marine habitats, although whether those preferences are real or arise from an ecologically biased sampling effort warrants supplementary research. For example, Protodrilus leuckartii prefers brackish waters and has been commonly found in coastal lagoons or estuarine areas, mostly in Italy and the south of France [28,177]. Small species, with segmental adhesive glands, such as the European Meiodrilus adhaerens and M. similis or the South American Claudrilus corderoi $[77,199,200]$, are often found deep in the sediment layers at the upper intertidal zone of sandy beaches. In contrast, the larger species are rather common at the surface of coarse or gravelly sediments. Species of Lindrilus seem to prefer the slope of exposed beaches [191,201], whereas a quite diverse assemblage of protodrilids can be found in coarse and gravelly subtidal sediments accumulated at the surf zone, including Protodrilus albicans and $M$. schneideri in the Atlanto-Mediterranean area $[28,45,46,202]$ and Protodrilus smithsoni, $P$. pythonius, and Megadrilus hochbergi around the Caribbean and Brazil [49,200,203]. These species cope with the turbulence in this highly hydrodynamic zone by exhibiting swimming behaviors facilitated by the well-developed body wall musculature and large size [28,49].

Only Megadrilus pelagicus and Protodrilus puniceus are known from non-interstitial environments. Megadrilus pelagicus is endemic to the La Corona lava tube, a $1600 \mathrm{~m}$ long anchialine lava tube in Lanzarote, Canary Islands [204], where it hoovers in the water column using its specialized ciliation in combination with its dorsal keel, feeding on suspended organic matter with its specialized long palps [205]. This species can also swim by producing muscular waves along its entire trunk, favored by the lateral compression of the body and the presence of a dorsal keel [41]. Protodrilus puniceus was described from whale falls off Cape Noma Misaki, Kyushu Island (Japan) at 219-254 m depth. This species forms dense aggregations in the countless small pores of whale bones. Some individuals completely bury themselves in these bones, whereas others were found partially emerged [30]. In aquaria, P. puniceus were observed to use their palps and midventral ciliary bands to gather small organic particles around the mouth. A similar protodrilid was reported from whale falls in Monterrey Bay, California (USA) [206]. A suspension feeding behavior has also been described for the species Protodrilus brevis, which lives interstitially or inside empty mollusk shells, using its palps to feed [28].

\subsubsection{Major Revisions and Most Important Literature}

The family Protodrilidae attracted comparatively a lot of attention during the end of the nineteenth century with the publication of several studies $[162,177,207,208]$, with a major review of the family by Umberto Pierantoni [189], who described most of the Mediterranean species as well as several details on the anatomy and larval development [189]. This research was followed up on by a revision by Gösta Jägersten from the Kristineberg Marine Research Station, who described the species diversity of the group in northern Europe and provided detailed studies on their larval development $[191,192,209]$. This work, along with a few papers targeting the description of new species from India [210,211], Washington (USA) [212], Brazil [108], and Egypt [135] was extensively reviewed by Claude Jouin $[28,213]$, who established the systematics of the family by describing the genera Astomus and Protodriloides, although the latter was later trasferred to the family Protodriloididae [180]. The last major morphological review of the family corresponds to the series of articles published by Hennig von Nordheim [186,214], who described several new species from Europe and New Zealand, providing a very useful overview of the family.

The current systematics of the family was established after an integrative cladistic analyses that included all described species of Protodrilidae, including those few described after the works by von Nordheim (e.g., $[41,49,196,200])$. This study split the family into six genera, each corresponding to a monophyletic clade [50]. 


\subsection{Protodriloididae Jouin, 1966}

\subsubsection{Phylogenetic Affinities}

Protodriloididae Jouin, 1966 is a family of interstitial annelids with two valid species reaching up to $13 \mathrm{~mm}$ in length. Both species were originally described as protodrilid, despite the conspicuous morphological differences between these species and family Protodrilidae. Indeed, Protodriloides symbioticus [215] was originally described as an aberrant species of Protodrilus due to the presence of greenish epidermal inclusions, initially interpreted as symbiotic algae [215], while Protodriloides chaetifer was described a few years later from Helgoland (Germany), mainly distinguished from the former by the presence of hooked chaetae [216]. The genus Protodriloides was erected by Jouin [217] following a detailed morphological analysis that revealed fundamental differences from that of Protodrilus [218]. Protodriloides was finally placed in Protodriloididae (originally spelled as Protodriloidae, modified by [167]) as a result of a morphological phylogenetic analysis of Astomus Jouin, 1979, Protodrilus Hatschek, 1881, Saccocirrus Bobretzky, 1872 and Protodriloides Jouin, 1966 [217].

\subsubsection{Morphology}

Protodriloididae are very characteristic and their overall aspect can be fairly described as sticky noodle-like worms-somewhat comparable to overcooked spaghetti. They have a pair of anterior palps that are short and stiff (Figure 12B). These palps resemble anterior extensions of the prostomium [180] and differ from those of the related Protodrilidae and Saccocirridae $[50,51]$ by lacking internal coelomic canals or basal ampullae (Figure 12C). The palps do, however, bear longitudinal ventral bands of motile cilia extending from near the base to the tip (Figure 12G,H).

Unlike members of Saccocirridae and Protodrilidae, species of Protodriloides have a small prostomium and lack pigmentation. They possess two pairs of unpigmented ciliary receptors, unique for the family [219], as well as a dorsal and a ventral ciliary band extending transversely near the border of the peristomium [220] (Figure 12A,C,G). The peristomium is longer than the prostomium and possesses a longitudinal slit-like mouth, a pair of lateral ciliary bands and discoid, densely ciliated nuchal organs (Figure 12G,H). Dorsal nuchal organs are well-developed in P. chaetifer, extending slightly obliquely to the longitudinal body axis, anterior to the peristomial lateral ciliary bands (Figure 12G), but they are reduced to inconspicuous dorsal papillae in Protodriloides symbioticus [20].

The trunk is elongated and compressed dorsoventrally. It consists of 45-50 segments in P. chaetifer, but only around 15-20 in P. symbioticus. Segments are indistinct in both species, delimited by incomplete septa (Figure 12B), and approximately equal in length, except for the shorter first segment $[218,221]$. The mid-ventral ciliary band extends from the mouth to the last four to five segments (Figure 12G,H), and, unlike in other families, covers approximately two thirds of the ventral side of each trunk segment [46]. Segmentally arranged sensory ciliated organs are present in P. symbioticus and P. chaetifer, consisting of groups of multiple cilia projecting from small papillae (Figure 12E). Segmentally arranged adhesive organs are exclusive for P. symbioticus [222], typically consisting of groups of 10-25 glandular cells arranged in dorsal, lateral and ventral pairs, which are aligned throughout the body, forming characteristic longitudinal bands [218]. A pair of bifid sigmoid chaetae is found exclusively on $P$. chaetifer, which additionally bears a curved and robust rostrum-like structure (Figure 12F) [216,218] that somewhat resembles those found across Clitellata or in the orbinid genus Questa.

The pygidium possesses a pair of lobes which is well-developed and rounded in $P$. chaetifer but somewhat smaller and less swollen in P. symbioticus (Figure 12D), but always smaller and thicker than that what is found in Protodrilidae and Saccocirridae [174,220]. 


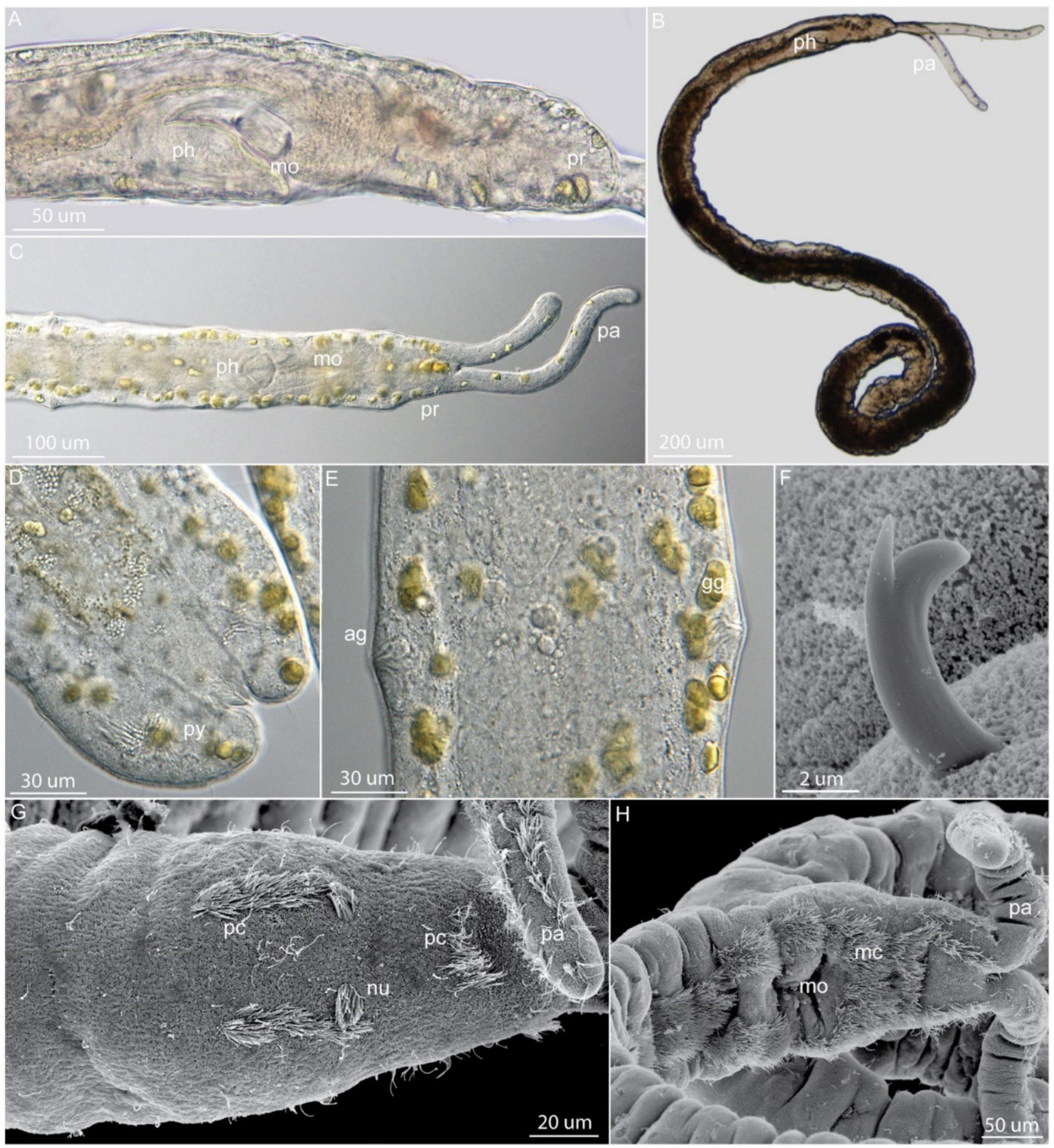

Figure 12. Morphology of Protodriloididae. (A-E) Protodriloides symbioticus (Roscoff, France), light micrographs. (F-H) Protodriloides chaetifer (Flakkerhuk, Greenland), scanning electron micrographs. (A) Lateral view of the anterior end. (B) Lateral overview of the body. (C) Dorsal view of the anterior end. (D) Dorsal view of the pygidium. (E) Dorsal view of a trunk segment. (F) Detail of the chaeta. (G) Dorsal view of the head. (H) Ventral view of the head. Abbreviations: ag, adhesive glands, gg green glands, mc mouth ciliation, mo mouth, nu nuchal organs, pa palp, pc prostomial ciliation, ph pharynx, pr prostomium, py pygidium. Reproduced with permission from [220]. 


\subsubsection{Taxonomy}

The only two described species of Protodriloides are mainly diagnosed by the presence or absence of chaeta, as well as by the arrangement of the epidermal glands along the trunk.

Protodriloides Jouin, 1966

Diagnosis: body elongated and flattened with a midventral ciliary band. Prostomium with two anterior palps lacking internal canals. Unpigmented prostomial receptors (socalled statocysts) and pigmented eyes absent. Two pairs of ciliary photoreceptor-like sensory organs are positioned behind the brain. Pharyngeal organ with bulbous and sagittal muscles as well as interstitial cells, but without a tongue-like organ. Salivary glands indistinct on the esophageal epithelium; not visible with light microscopy. Epidermis with green vacuolar glands. Pygidium with two rounded adhesive lobes. Fertile segments in the posterior half of the body. Males without lateral organs and with spermioducts in each fertile segment. Spermatozoa round and aflagellate. Large yolky eggs laid in cocoons produced by female cocoon glands. Fertilization and direct development inside the cocoon [220].

Two species. Type species: Protodriloides symbioticus Giard, 1904; P. chaetifer Remane, 1922.

\subsubsection{Distribution and Diversity}

The two described species of Protodriloididae have been recorded worldwide, except for Antarctica. Most records are from European coastal waters, reflecting a higher sampling effort here [220]. Protodriloides symbioticus was described in Ambleteuse, France [215] and has been mostly found in Northeastern Atlantic waters thereafter [199,216-218,222-228], although with a few records in Northern America and the Mediterranean Sea (CuriniGalletti et al. accepted; $[189,229,230])$. In contrast, Protodriloides chaetifer was originally described from Helgoland, Germany [216] and has subsequently been mainly recorded from Europe [199,218,227,228,231-235], but also occasionally in the Arctic [236,237] and Pacific oceans [74,212]. Most of these records are from intertidal to shallow subtidal medium-coarse sediments; often associated with the presence of groundwater submarine discharge [220]. Although RAFLP data [157] indicate that the P. chaetifer records comprise a complex of at least four cryptic species, the widely distributed records are still in need of careful review using integrative taxonomical studies, combining detailed morphological examinations with molecular methods. In contrast, the possibility of $P$. chaetifer dispersing due to stochastic catastrophic phenomena has recently been suggested in the area of Kerala (India), which was recently affected by a tsunami in 2006 [238].

\subsubsection{Major Revisions and Most Important Literature}

Main reviews of the family were provided by Jouin [218] and Purschke and Jouin [217], and recently updated by Martínez, Worsaae, and Purschke [220].

\subsection{Psammodrilidae Swedmark, 1952}

\subsubsection{Phylogenetic Affinities}

The eight described species of Psammodrilidae range in length from 1 to $8 \mathrm{~mm}$ and exhibit synapomorphic features such as thoracic motile cirri (with internal aciculae), a muscular collar region with unciliated "warty" epidermal cells and an almost entirely ciliated body, making them well-adapted to ciliary gliding between sand grains. Despite this aberrant morphology, their specialized hooked chaetae (uncini with barbules) resemble those of Arenicolidae and Maldanidae (e.g., [239,240]), causing them to ally with uncinibearing families in Sedentaria in morphological phylogenies [241,242]. However, this hypothesis is rejected in phylogenomic analyses based on transcriptomic data [9], instead placing Psammodrilidae together with Apistobranchidae and Chaetopteridae (lacking uncini) in the basally branching Chaetopteriformia.

Morphologically, psammodrilids were previously divided into two genera: Psammodrilus, including the larger semi-sessile species that possesses a proposedly mucus-secreting 
collar region and Psammodriloides, which included the small-sized P. fauveli that lacks this collar and moves freely among the interstices [7]. However, the discovery of intermediate forms and life stages led to the synonymization of Psammodriloides with Psammodrilus [243]. This was further supported by a phylogenetic analysis of the family relying on increased taxon sampling [21], which showed that several small-sized species $[239,243,244]$ have evolved secondarily and several times within the family from larger species [21] (Figure 13).

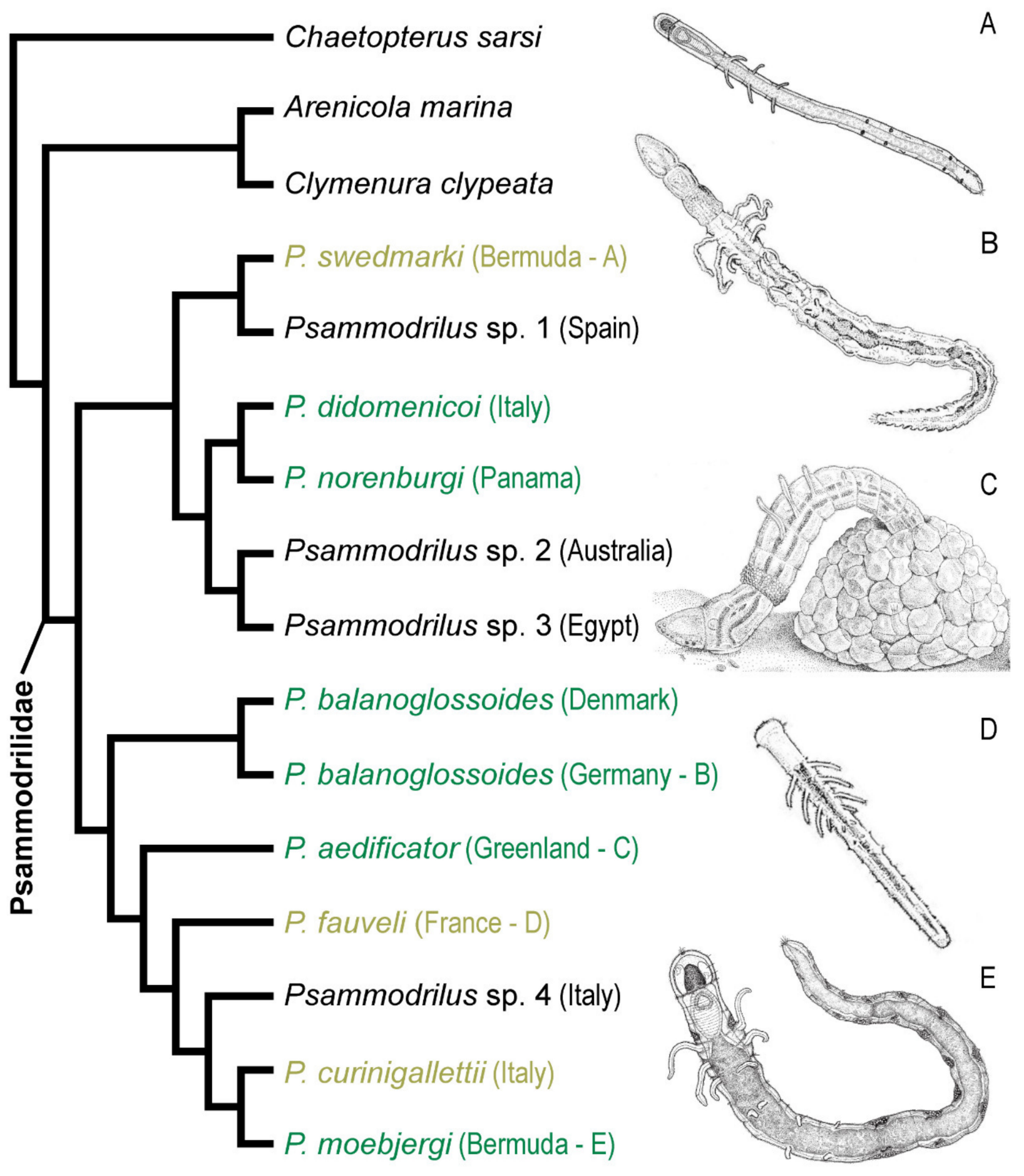

Figure 13. Phylogenetic tree of Psammodrilidae based on direct optimization parsimony analyses of combined molecular and morphological data (modified from [21]). Small-sized, collar-lacking species in olive green font two of which illustrated in (A,D), large-sized species in dark green font three of which illustrated in (B,C,E), psammodrilids of unknown size in black font. 
These specializations are likely to have occurred through progenesis, since the smallsized species show great resemblance to juvenile stages of large-sized species, not yet having developed a collar, pharyngeal muscular diaphragms or as many chaetae and dorsal cirri [21,243]. The convergent and varying degree of regressive adaptations to a vagile, interstitial life form not only indicates that the development and morphology of Psammodrilidae is genetically susceptible to progenesis, causing the family to diversify worldwide throughout its long history [21,243], but also supports the suggestion that the family evolved from a larger, tube-building macrofaunal ancestor, as indicated by its position in Chaetopteriformia [9].

\subsubsection{Morphology}

The cylindrical coelomate body of psammodrilids comprises three different regions: a head (prostomium+peristomium), a thorax with six well defined segments, and an abdomen of varying length carrying uncini (Figure 14). The prostomium has an anterior apical sensory organ with compound cilia, lacking appendages and eyes and includes more or less well-developed prostomial coeloms with diaphragm sacs facilitating changes in prostomial length and width. The elongated peristomium bears an anterior ventral mouth opening and a posterior muscular pharyngeal apparatus depicting various levels of complexity. The larger species possess a complex suctorial pharynx containing muscular diaphragms and two coelomic muscle sacs within a collar of non-ciliated polygonal epidermal cells (in P. moebjergi limited to two lateral areas of collar cells). It is not yet clear whether the collar region constitutes the posterior part of the peristomium or an individual segment [245]. In the smaller species, the musculature is reduced, and the collar cells are missing.

The thorax carries one to six pairs of dorsal muscularized cirri of differing length and with internal pliable aciculae proximally nested within the ventral musculature. The abdomen lacks parapodia but carries paired groups of 1 to 16 lateroventral sigmoid uncini per segment (greatest number found in posterior segments) as well as a pygidium with a dorsal to terminal anus and compound sensory cilia. The epidermis is completely ciliated except in the collar region and the dorsal midline of thorax and abdomen. Rings of longer cilia delineate the prostomium, peristomium, and thoracic segments.

A range of unicellular glands are scattered throughout the epidermis, with numerous mucus glands on the head and ventral thorax seemingly aiding ciliary locomotion [239]. Numerous adhesive glands on the abdomen and cirri have such adhesive power that the animals easily get stuck in a petri dish and may rip them self apart (e.g., [236,243]). Segmental, multicellular, diamond-shaped glands are found dorso-laterally in the thorax and abdomen of P. curinigallettii [244]. The collar cells have well-developed Golgi complexes, and it has been proposed that they secrete mucus (possibly forming tubes) along the intercellular spaces where they interdigitate [236].

Body wall musculature is relatively simple with multiple longitudinal muscles sometimes forming two ventral and two dorsal bundles, as well as oblique muscles supporting the aciculae and thin outer circular muscles [244]. However, the unique suctional pharynx of larger psammodrilids is supported by several layers of both circular and longitudinal muscles, which together with an anterior and a posterior transverse muscular diaphragm aid in contracting or expanding the pharynx and the intake of detritus $[245,246]$. When moving through the sediment, a combination of muscles and coelomic cavities support the high flexibility of the prostomial shape (from anchor shaped to pointed).

Psammodrilids possess a variable number of paired metanephridia, being more developed with additional cilia in the larger species. The intraepidermal nervous system is poorly studied but comprises a dorsal brain and ganglionated paired ventro-lateral nerve cords $[9,94,245]$.

Psammodrilids are gonochoristic, except for the hermaphroditic $P$. curinigallettii and $P$. moebjergi, producing both oocytes and sperm. Spermatozoa have ellipsoidal to elongate heads and long flagellate tails $[243,244]$. Fertilization is expectedly external but spermath- 
ecae were found in P. swedmarki, which suggests that some species might copulate [243]. Development is direct [245].

\subsubsection{Taxonomy}

Large-sized psammodrilids are identified based on the number of rows of cells in the collar, length and number of thoracic cirri, reproductive and glandular structures andshape and number of chaetae per segment. However, small-sized species have highly similar (and sometimes convergent) morphology, often only differing in combinations of absent features and variation in the number and length of structures rather than by the presence of species-specific autapomorphies. This makes taxonomy of Psammodrilidae extremely challenging and the presence of sexually mature stages crucial for morphological characterization. Molecular barcoding and comparison are therefore generally warranted to assure correct identification of psammodrilids.

Psammodrilus Swedmark, 1952

Eight described species, including synonymized Psammodriloides Swedmark, 1958. Type species: Psammodrilus balanoglossoides Swedmark, 1952; P. fauveli (Swedmark, 1958)

(as Psammodriloides fauveli); P. aedificator Kristensen and Nørrevang, 1982; P. moebjergi, P. swedmarki Worsaae and Sterrer, 2006; P. curinigallettii Worsaae, Kvindebjerg, and Martínez, 2015; P. didomenicoi, P. norenburgi Worsaae and Martínez, 2018. See Table 3 for morphological characteristics and distribution.

Table 3. List of main characters for the eight described species of Psammodrilidae (modified from [21]). Abbreviations: abdom., abdominal; max., maximum; rud., rudimental; segm., segment; \#, number.

\begin{tabular}{|c|c|c|c|c|c|c|c|c|c|}
\hline Species & Locality & $\begin{array}{l}\text { Max. Body } \\
\text { Length } \\
\text { (mm) }\end{array}$ & $\begin{array}{l}\text { Max. Body } \\
\text { Width } \\
\text { (mm) }\end{array}$ & $\begin{array}{l}\text { Prostomial } \\
\text { Sacs }\end{array}$ & $\begin{array}{l}\text { Pharyngeal } \\
\text { Muscula- } \\
\text { ture }\end{array}$ & $\begin{array}{l}\text { Polygonal } \\
\text { Collar } \\
\text { Cells }\end{array}$ & $\begin{array}{l}\text { Thoracic } \\
\text { Cirri } \\
\text { (Pairs) }\end{array}$ & $\begin{array}{c}\text { Max.\# } \\
\text { Abdom. } \\
\text { Segm. }\end{array}$ & $\begin{array}{l}\text { Max. \# } \\
\text { Uncini/ } \\
\text { Ramus }\end{array}$ \\
\hline P. aedificator & $\begin{array}{l}\text { Disko, W } \\
\text { Greenland } \\
\text { North }\end{array}$ & 8.1 & 0.19 & Present & $\begin{array}{c}\text { Well } \\
\text { developed }\end{array}$ & ca. 10 rows & $\begin{array}{l}3 \text { long, } 3 \\
\text { short }\end{array}$ & 20 & $3(5)$ \\
\hline $\begin{array}{c}P . \\
\text { balanoglos- } \\
\text { soides }\end{array}$ & $\begin{array}{l}\text { Atlantic; } \\
\text { White Sea; } \\
\text { New } \\
\text { Zealand }\end{array}$ & $5-6$ & 0.15 & Present & $\begin{array}{c}\text { Well } \\
\text { developed }\end{array}$ & $>25$ rows & $\begin{array}{c}2 \text { long, } 1 \\
\text { medium, } 3 \\
\text { short }\end{array}$ & 31 & 16 \\
\hline $\begin{array}{c}P . \\
\text { didomenicoi }\end{array}$ & $\begin{array}{l}\text { Napoli, } \\
\text { Italy }\end{array}$ & 1.9 & 0.13 & Present & $\begin{array}{c}\text { Well } \\
\text { developed }\end{array}$ & $\begin{array}{c}\text { ca. } 7-8 \\
\text { rows }\end{array}$ & $\begin{array}{c}2 \text { short, } 3 \\
\text { rud. } \\
3 \text { medium, }\end{array}$ & 11 & 5 \\
\hline P. fauveli & $\begin{array}{c}\mathrm{NE} \\
\text { Atlantic }\end{array}$ & 1 & 0.13 & Absent & Absent & absent & $\begin{array}{l}1 \text { short, } 2 \\
\text { rud. or } \\
\text { none }\end{array}$ & 10 & 1 \\
\hline P. moebjergi & Bermuda & 2.2 & 0.11 & Present & Absent & $\begin{array}{l}2 \text { lateral } \\
\text { clusters }\end{array}$ & $\begin{array}{c}2 \text { medium, } \\
1 \text { short, } 3 \\
\text { rud. }\end{array}$ & 11 & 4 \\
\hline $\begin{array}{c}P . \\
\text { norenburgi }\end{array}$ & $\begin{array}{c}\text { Bocas del } \\
\text { Toro, } \\
\text { Panama }\end{array}$ & 3.5 & 0.18 & Present & $\begin{array}{c}\text { Well } \\
\text { developed }\end{array}$ & ca. 25 rows & $\begin{array}{c}3 \text { long (or } 2 \\
\text { long + } 1 \\
\text { medium), } \\
2-3 \text { short }\end{array}$ & ? & 5 \\
\hline $\begin{array}{c}P . \\
\text { swedmarki }\end{array}$ & Bermuda & 1.6 & 0.06 & Absent & Absent & Absent & $\begin{array}{l}3 \text { long, } 1-2 \\
\text { rud. or } \\
\text { none }\end{array}$ & 7 & 2 \\
\hline
\end{tabular}

Furthermore, at least nine potentially new species may exist for which details are lacking. Sequences are published from four undescribed species found off Lanzarote (Canary Islands), Lizard Island (NE Australia), Dahab (Egypt), and Campania (Italy) (Figure 1 in [21]). Recently, two seemingly undescribed species were found off Iriomote, Japan and off Amsterdam Island, French Southern and Antarctic Lands (Worsaae, unpublished). Moreover, Psammodrilus balanoglossoides, originally described off Roscoff, France, has been reported from widely separated geographic areas, including the White Sea [247], Barents Sea [237] and off Florida (USA) [243] and New Zealand [74]. Since even the two only sequenced populations of P. balanoglossoides from the North Sea and Baltic Sea, respectively, 
showed significant differences in 18S rRNA [21], the disparate records of $P$. balanoglossoides will most likely reveal several cryptic species.
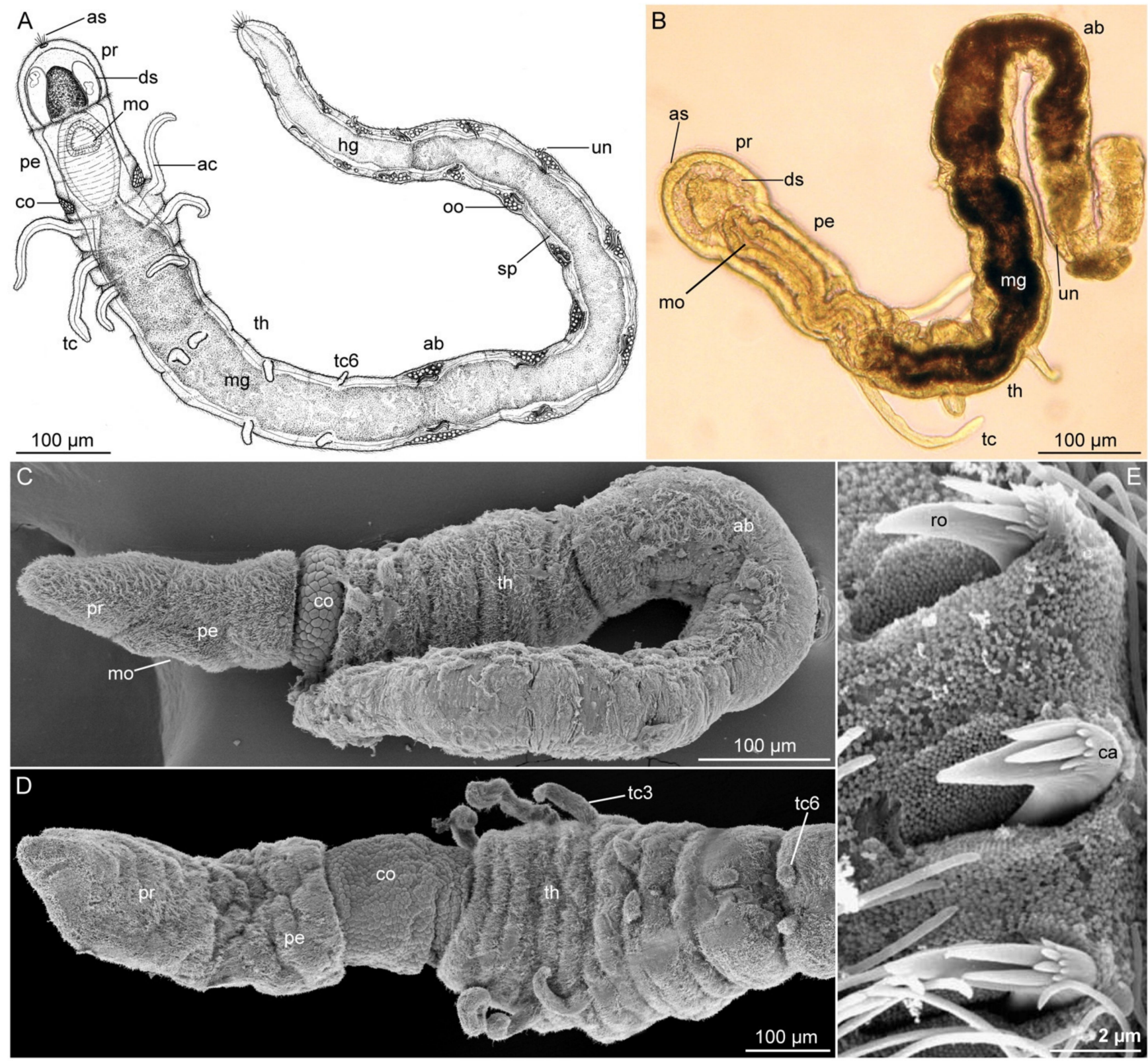

Figure 14. Morphology of Psammodrilidae. (A) Schematic illustration of Psammodrilus moebjergi. (B) Light micrograph of P. moebjergi, hind end lost. (C-E) Scanning electron micrographs. (C) Psammodrilus didomenico. (D) Anterior end of P. balanoglossoides from Denmark. (E) Uncini of P. moebjergi. (A,B,E) modified from [248]; (C), modified from [21]. Abbreviations: ab, abdomen; ac, acicula; as, anterior sensory cilia; ca, capitium; co, collar; ds, prostomial diaphragm sac; hg, hindgut; mg, midgut; mo, mouth opening; oo, oocyte; pe, peristomium; pr, prostomium; ro, rostrum; sp, sperm; tc, thoracic cirrus; tc3, tc6, third and sixth thoracic cirri; th, thorax; un, uncinus.

\subsubsection{Distribution and Diversity}

Psammodrilids are extremely fragile with their nearly entire ciliated epidermis and reduced cuticle, often breaking or disintegrating easily during collection and handling. This, in combination with an elusive and juvenile appearance of the small species, may be the reason why they are easily overlooked in meiofauna surveys and generally only found in low numbers, despite living in shallow subtidal, sandy-gravelly sediments. However, in the numerous new findings during recent meiofauna surveys ([21,245], Worsaae, unpub- 
lished) have expanded their distribution to most major oceans, suggesting a worldwide distribution and a high number of cryptic species [245].

\subsubsection{Major Revisions}

The evolution, morphology, and biology of psammodrilids are treated in the following major papers and references herein: Swedmark [246], Worsaae and Kristensen [7], Helm et al. [9], Worsaae et al. [21], and Worsaae [245].

\subsection{Saccocirridae Bobretzky, 1872}

\subsubsection{Phylogenetic Affinities}

Saccocirridae contains two valid genera with a total of 23 interstitials species. A combined phylogenetic analysis by Di Domenico et al. [51] using molecular and morphological data revealed that each of the 23 described species could be separated into two genera, namely Saccocirrus and Pharyngocirrus. These two clades were previously acknowledged as the "papillocercus" (= Saccocirrus) species complex and the "krusadensis" (= Pharyngocirrus) species complex in several earlier studies [53,217,248-251].

The systematic position of Saccocirridae within Annelida appears to be better resolved: Protodrilida (the clade Saccocirridae belongs to) plus Polygordiidae are united in a clade called Protodriliformia, which is a sister group to Phyllodocida and Eunicida within Errantia $[10,11,252]$. Saccocirridae are thought to have evolved by gradual miniaturization from macroscopic ancestors rather than by progenesis, as proposed for several other interstitial annelids, supported not only by their comparatively large size, but also by certain other characteristics, such as a life with trochophore larva and the presence of parapodia and chaetae [11].

\subsubsection{Morphology}

Species of Saccocirridae show body lengths ranging from 0.3 to $8 \mathrm{~cm}$ and comprise up to about 200 segments $[51,53,248,250,253,254]$. Compared to other interstitial and meiofaunal animals, saccocirrids have a large body. Since saccocirrids inhabit coarse sands, some species, such as Saccocirrus major, have macrofaunal body size dimensions. All saccocirrid species are characterized by the presence of two long and highly flexible muscular palps, small cylindrical uniramous parapodia with simple, retractable chaetae and a bilobed adhesive pygidium (Figures 15A,B and 16A,B,D). Depending on the species, the ventral palps are between 0.2 and $1.5 \mathrm{~mm}$ long and supplied with an internal coelomic canal that fuses with its corresponding canal from the opposite side behind the brain, and a pair of basal sac-like structures (= ampullae) that extend longitudinally until the first or third segment in all species.

Nuchal organs are present, and their size varies greatly among species. The eyes are situated anteriorly on the prostomium $[51,83,249]$. Whereas the small, pigmented eyes are easily seen with the light microscope, other, usually unpigmented photoreceptive sensory organs may be present as well, which, as a rule, can only be detected by TEM.

The digestive system of Saccocirridae comprises a ventral mouth, a buccal cavity with or without a muscular pharynx, a long esophagus, intestine, and a terminal anus $[53,217,255,256]$. The pharyngeal region of S. papillocercus and other Saccocirrus spp. bears dorsolateral ciliary folds but lacks a muscular ventral pharynx, whereas in Pharyngocirrus spp. possess a muscular pharynx (Figures 15A and 16A) [51,250,253,257-259].

Parapodia are uniramous, cylindrical and without lobes or cirri, bearing 5 to 10 chaetae (Figure 16C,F). Small ciliary tufts are present on the ventral side of the parapodia. Three types of chaetae are usually identified in Saccocirridae: long, medium and short [250] (Figure 16C,F). The longest chaetae in Saccocirrus species are robust and forked, whereas Pharyngocirrus species have delicate fan-shaped lyrate chaetae [51], which can be either asymmetrical or bilateraly symmetric. The medium length chaetae are spatulated to oarshaped or have a smooth apex in Saccocirrus, or bifid with two equally long prongs in 
Pharyngocirrus. The shortest (and thinnest) chaetae are spatulated with a smooth tip in Saccocirrus and bifid with a notched apex in Pharyngocirrus.

A

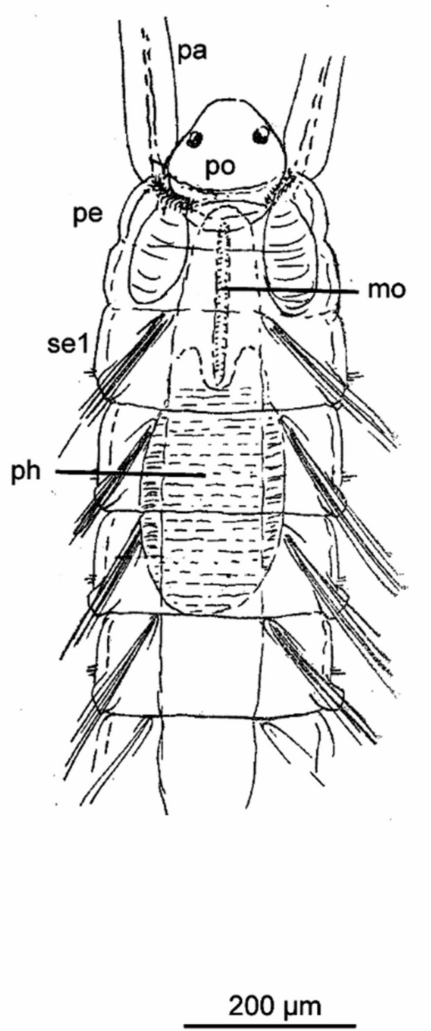

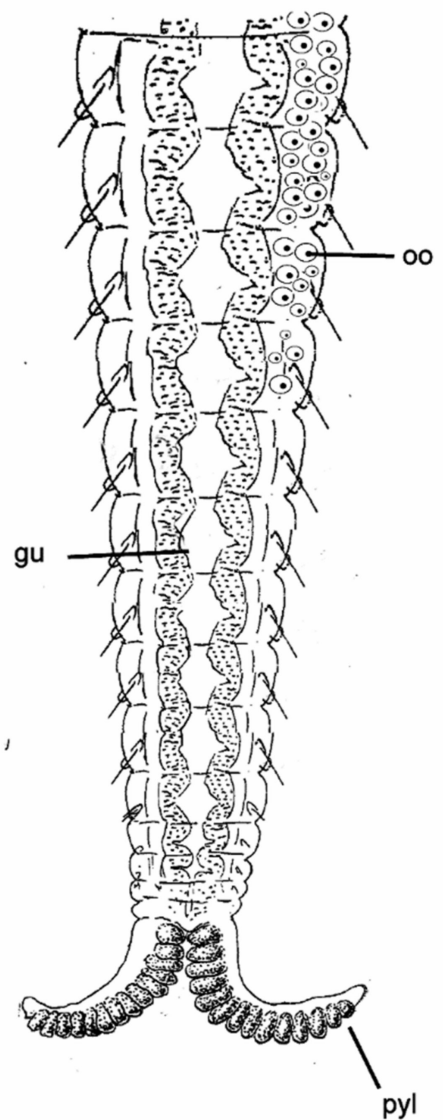

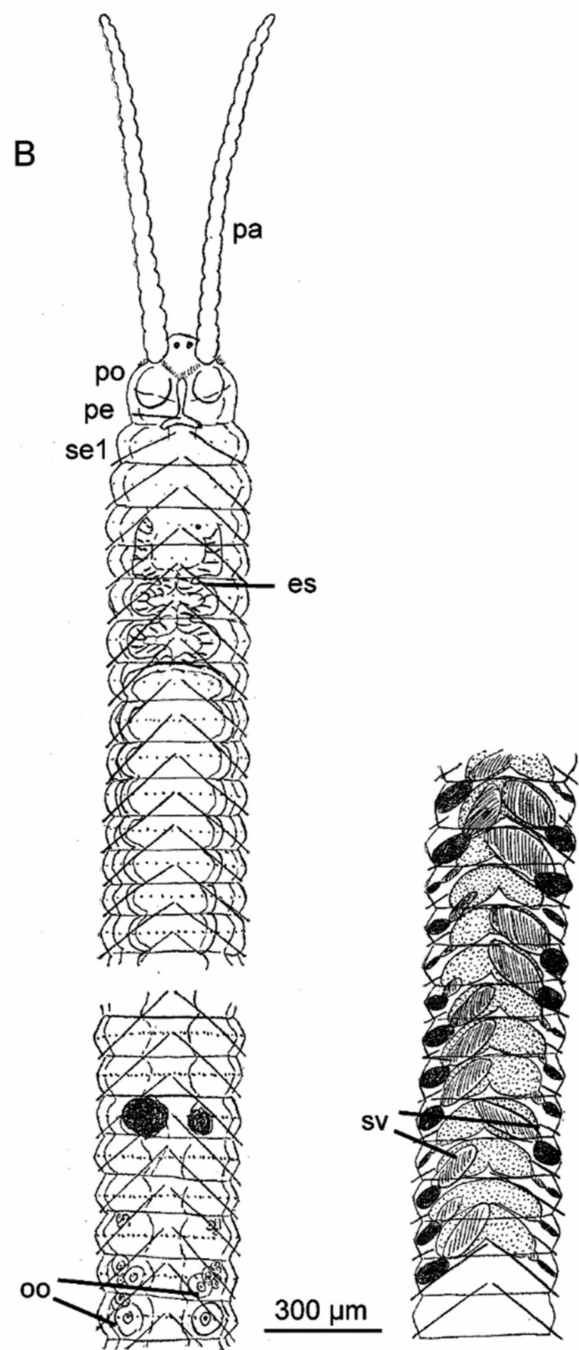

Figure 15. Saccocirridae species. (A) Drawing of Pharyngocirrus gabriellae, showing a female with an unpaired reproductive system and oocytes arranged on the right side of the gut (dorsal view). (B) Drawing of Saccocirrus pussicus showing the paired reproductive system of a female (oocytes) and a male (seminal vesicule). Abbreviations: es, esophagus; gu, gut; mo, mouth opening; oo, oocytes; pa, palps; pe, peristomium; ph, pharynx; po, prostomium; pyl, pygidial lobe; se1, segment 1; sv, seminal vesicle. References: Drawing (A) is modified from [260], and drawing (B) is modified from [108], acknowledging copyright permissions from publishers.

Saccocirridae usually possess adhesive glands that open on the pygidial lobes and on the trunk segments. These are generally well-developed and most likely necessitated by the turbulent environment most species live in. However, in a few species, the adhesive glands are less developed, as in Saccocirrus minor or Pharyngocirrus jouinae. The adhesive glands open in transverse rows with usually three gland cells opening in a common small papilla in the trunk region (Figure 16E).

The reproductive system is unpaired in Pharyngocirrus species and paired among Saccocirrus species $[51,248]$. Within each genus, the species differ in their distinct number of fertile segments, presence or absence of ovaries, size of mature oocytes, number of segments with oocytes, and position of the testes [51,248]. 


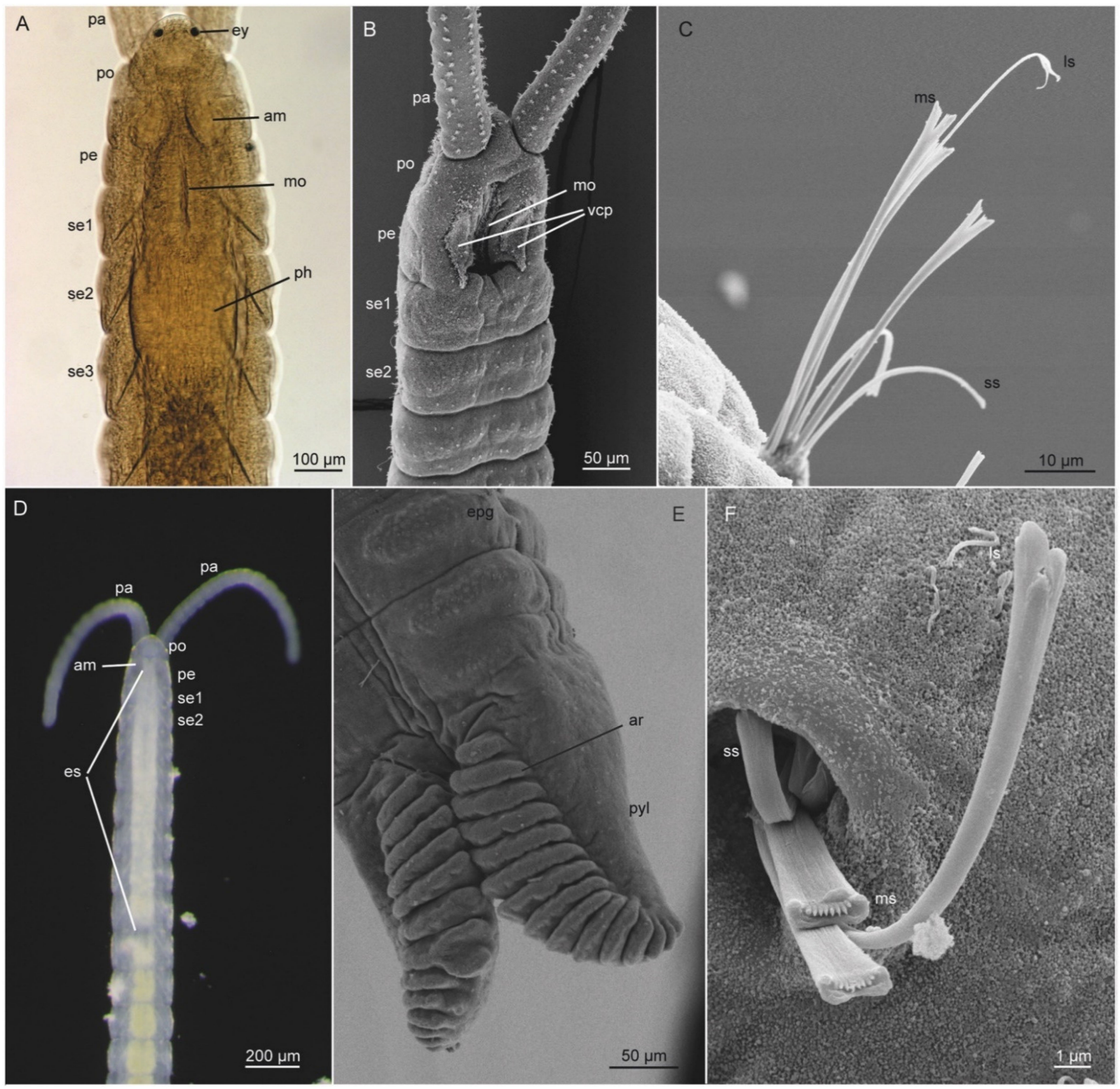

Figure 16. Morphology of Saccocirridae. (A-C) Pharyngocirrus. (D-F) Saccocirrus. (A) Light microscopy of Pharyngocirrus sp. (Bocas del Toro, Panamá). (B) Scanning electron micrograph of Pharyngocirrus sp. (Bird Rock, CA, USA). (C) Scanning electron micrograph of Pharyngocirrus sp. (Bocas del Toro, Panamá). (D) Light microscopy of Saccocirrus sp. (Bermuda), dorsal view. (E) Saccocirrus slateri (Abades, Tenerife, Canary Island). (F) Saccocirrus sp. (Mala, Lanzarote, Canary Island). Abbreviations: am, ampullae; ar, adhesive ridges; epg, epidermal adhesive glands; es, esophagus, ey, eye (ocellus); ls, longest setae; mo, mouth opening; ms, medium setae; pa, palps; pe, peristomium; ph, pharynx; po, prostomium; pyl, pygidial lobe; s, setae; se, setiger; ss, shortest setae; vcp, ventral (mouth) ciliary patch.

\subsubsection{Taxonomy}

The following characteristics are the main morphological features used to identify Saccocirridae species: number of segments, type of chaetae, number and shape of appendages (palps, antennae, parapodial and pygidial cirri), and type of reproductive organs (paired or unpaired), as well as size, number, and position of seminal vesicles and oocytes. A list of valid species for each genus is listed below (see Table 4). 
Table 4. Meristic and morphometric characters of described species of Saccocirrus and Pharyngocirrus. Abbreviations: L, length; W, width; Max, maximum; \#, number; pyg. adh., pygidial adhesive; Fem, Female; segm., segment; ?, unknown.

\begin{tabular}{|c|c|c|c|c|c|c|c|c|c|c|c|c|}
\hline Species & $\begin{array}{c}\text { Max L. } \\
(\mathrm{mm})\end{array}$ & $\begin{array}{c}\operatorname{Max} W . \\
(\mu \mathrm{m})\end{array}$ & $\begin{array}{l}\text { Max \# } \\
\text { Segm. }\end{array}$ & $\begin{array}{c}\text { Max \# } \\
\text { pyg. } \\
\text { adh. } \\
\text { Ridges }\end{array}$ & $\begin{array}{c}\text { Pharyng } \\
\text { Bulb }\end{array}$ & $\begin{array}{l}\text { 1Gonads } \\
\text { Fem. }\end{array}$ & $\begin{array}{c}\quad \# \\
\text { Fertile } \\
\text { Segm. }\end{array}$ & $\begin{array}{c}\text { Gonads } \\
\text { Males }\end{array}$ & $\begin{array}{l}\text { Ciliary } \\
\text { Groove }\end{array}$ & $\begin{array}{l}\text { Ciliary } \\
\text { Patches } \\
\text { Mouth }\end{array}$ & $\begin{array}{l}\text { Longest } \\
\text { Chaetae }\end{array}$ & $\begin{array}{l}\text { Prongs } \\
\text { Length }\end{array}$ \\
\hline \multicolumn{13}{|c|}{ Saccocirrus } \\
\hline S. slateri & 25 & 730 & 155 & 22 & absent & bilateral & 72 & bilateral & absent & absent & forked & equal \\
\hline $\begin{array}{l}\text { S. papi- } \\
\text { locercus }\end{array}$ & 30 & 400 & 150 & 8 & absent & bilateral & 120 & bilateral & absent & absent & forked & equal \\
\hline S. major & 70 & 1000 & 200 & 14 & absent & bilateral & 175 & bilateral & absent & absent & forked & equal \\
\hline S. minor & 15 & 200 & 100 & absent & absent & bilateral & 40 & bilateral & absent & absent & forked & equal \\
\hline $\begin{array}{l}\text { S. orien- } \\
\text { talis }\end{array}$ & 12 & $?$ & 170 & 4 & absent & bilateral & 60 & bilateral & absent & absent & forked & equal \\
\hline $\begin{array}{l}\text { S. } \\
\text { pussicus }\end{array}$ & 30 & 400 & 120 & 12 & absent & bilateral & 36 & bilateral & absent & absent & forked & unequal \\
\hline $\begin{array}{l}\text { S. hete- } \\
\text { rochaetus }\end{array}$ & 9 & 300 & 74 & absent & absent & bilateral & 20 & bilateral & absent & absent & forked & unequal \\
\hline $\begin{array}{l}\text { S. } \\
\text { parvus }\end{array}$ & 3 & 280 & 70 & absent & absent & bilateral & $?$ & bilateral & absent & absent & forked & unequal \\
\hline $\begin{array}{l}\text { S. } \\
\text { oahuen- } \\
\text { sis }\end{array}$ & 10.5 & 400 & 119 & 6 & absent & bilateral & $?$ & bilateral & absent & absent & forked & unequal \\
\hline $\begin{array}{l}\text { S. wa- } \\
\text { ianaen- } \\
\text { sis }\end{array}$ & 10 & 450 & 210 & absent & absent & bilateral & $?$ & bilateral & absent & absent & forked & unequal \\
\hline $\begin{array}{l}\text { S. } \\
\text { cirratus }\end{array}$ & 45 & $?$ & 200 & absent & present & bilateral & 115 & bilateral & absent & present & lyrid & unequal \\
\hline \multicolumn{13}{|c|}{ Pharyngocirrus } \\
\hline $\begin{array}{l}\text { P. archi- } \\
\text { boldi }\end{array}$ & 6 & 200 & 84 & absent & present & $?$ & $?$ & $?$ & absent & present & spatulated & $?$ \\
\hline $\begin{array}{l}\text { P. kru- } \\
\text { sadensis } \\
P .\end{array}$ & 25 & 400 & 150 & 9 & present & left & 80 & left & absent & present & lyrid & unequal \\
\hline $\begin{array}{l}\text { gabriel- } \\
\text { lae }\end{array}$ & 30 & 400 & 160 & 15 & present & right & 100 & left & present & present & lyrid & equal \\
\hline $\begin{array}{l}P . \\
\text { eroticus }\end{array}$ & 22 & 300 & 125 & 22 & present & right & 110 & left & present & present & lyrid & equal \\
\hline P. labilis & 14 & 250 & 133 & 9 & present & left & 100 & left & present & present & lyrid & unequal \\
\hline $\begin{array}{l}\text { P. sono- } \\
\text { macus }\end{array}$ & 25 & 330 & 140 & 12 & present & right & 55 & left & absent & present & lyrid & equal \\
\hline $\begin{array}{l}P . \\
\text { jouinae }\end{array}$ & 20 & 550 & 120 & $?$ & present & unilateral & $?$ & unilateral & present & present & lyrid & unequal \\
\hline $\begin{array}{l}\text { P. tri- } \\
\text { dentiger }\end{array}$ & 20 & 600 & 100 & 14 & present & unilateral & $?$ & unilateral & $\begin{array}{c}\text { to segm. } \\
8\end{array}$ & present & lyrid & unequal \\
\hline $\begin{array}{l}P . \\
\text { uchidai }\end{array}$ & 20 & 350 & 146 & 23 & present & left & 100 & left & present & present & lyrid & equal \\
\hline $\begin{array}{l}P . \\
\text { goodrichi }\end{array}$ & 15 & 300 & 130 & 7 & present & left & 35 & unilateral & absent & absent & lyrid & unequal \\
\hline $\begin{array}{l}\text { P. alan- } \\
\text { hongi }\end{array}$ & 3.4 & 300 & 47 & 6 & present & unilateral & $?$ & unilateral & $\begin{array}{l}\text { segm. } 1 \\
\text { to } 3\end{array}$ & present & lyrid & unequal \\
\hline $\begin{array}{l}P . \\
\text { burchell }\end{array}$ & 20 & 1000 & 200 & 10 & present & unilateral & 180 & unilateral & absent & present & absent? & unequal \\
\hline
\end{tabular}
Table 4)

Pharyngocirrus Di Domenico, Martínez, Lana, and Worsaae 2014 (Figures 15A and 16A-C,

Diagnosis: Brown body. Prostomium with two pigmented eyes and long filiform palps. Presence of prostomial transverse ciliary band. Mouth surrounded by ciliary patches consisting of paired longitudinal bands. Mid-ventral ciliary band may be present.

Ventral muscular pharynx present. Uniramous parapodia with three types of chaetae: (1) long capillary chaetae lyrate (equal or unequal sides) with a small median tooth; (2) medium bifid chaetae with equal lateral prongs; and (3) short chaetae with notched apex. Females have unilateral ovaries on the right or left side of the gut. Males have unilateral seminal vesicles on the right or left side of the gut. 
Thirteen described species. Type species: Pharyngocirrus gabriellae (Du Boys-Reymond Marcus, 1946); P. krusadensis (Alikunhi, 1946); P. eroticus (Gray, 1969); P. labilis (Yamanishi, 1973); P. archiboldi (Kirsteuer, 1967); P. sonomacus (Martin, 1977); P. jouinae (Brown, 1981); P. tridentiger (Brown, 1981); P. uchidai (Sasaki, 1981); P. goodrichi, (Jouin-Toulmond and Gambi, 2007); P. burchelli (Silberbauer, 1969); P. alanhongi (Baley-Brock, Dreyer, and Brock, 2003).

Saccocirrus Bobretzky, 1872, (Figures 15B and 16D-F, Table 4)

Diagnosis: Brown body. Prostomium with two pigmented eyes and long filiform palps. Uniramous parapodia with three types of chaetae: (1) one to two long chaetae, robust and forked with equal or unequal prongs; (2) two to three medium spatuled chaetae; and (3) two to three short spatuled chaetae with notched apex. Females have bilateral ovaries. Males have bilateral seminal vesicles.

Eleven described species. Type species: Saccocirrus papillocercus Bobretzky, 1872; S. major Pierantoni, 1907; S. orientalis Alikunhi, 1946; S. minor Aiyar and Alikunhi, 1944; S. pussicus Du Bois-Reymond Marcus, 1948; S. heterochaetus Jouin, 1975; S. parvus Gerlach, 1953; S. oahuensis Baley-Brock, Dreyer and Brock, 2003; S. waianaensis Bailey-Brock, Dreyer and Brock, 2003; S. cirratus Aiyar and Alikunhi, 1944; S. slateri Di Domenico, Martínez and Worsaae, 2019.

\subsubsection{Distribution and Diversity}

Saccocirridae are found in medium to coarse sediments and gravel, from intertidal to subtidal regions. Records from the deeper sublittoral zone and the deep sea are lacking. These species are usually recorded from sandy beach environments [53,108,251,260-262]. A revision of the literature showed that Pharyngocirrus occurs intertidally on sheltered beaches, bays, or coves, as well as between rocks in tidal pools or subtidally. Generally, these animals occur in coarse sand with a well-defined redox layer. Species of Saccocirrus live intertidally in well-oxygenated coarse sand of exposed beaches and can often be found in the surf zone where they are hunting for prey or animals damaged by wave action. These annelids cling to sand grains or shells using their caudal appendages and sticky skin (caused by mucous produced by adhesive glands), particularly in high hydrodynamic environments [53,185,251,254,260].

Both genera are usually found worldwide in the tropical to temperate zones, but most species are described in warmer waters [51,248], except Pharyngocirrus eroticus, described near Orcas Island, on the west coast of North America [263]. The first reported species of Saccocirridae was Saccocirrus papillocercus, described in 1871 at Sebastopol Bay, Crimea peninsula, Black Sea [264]. Since then, S. papillocercus has been reported by several authors from the Mediterranean Sea $[250,265,266]$ and North Atlantic $[267,268]$. The deepest record of the family is Saccocirrus waianaensis, found between 30 and $35 \mathrm{~m}$ off Oahu Island, Hawaii [269]. So far, records from boreal and polar latitudes are lacking. Geographic analyses yielded a well-supported diversity gradient for Saccocirridae, with a maximal diversity estimated at $20^{\circ} \mathrm{N}$, and with $95 \%$ of the diversity being found between $0^{\circ}$ and $30^{\circ} \mathrm{N}$ [254]. Distribution patterns of the described species of Saccocirridae have been summarized in Di Domenico et al. [51].

\subsubsection{Major Revisions and Most Important Literature}

Multiple studies have addressed the diversity and systematics of saccocirrids, but some of the most recent larger revisions include Jouin-Toulmond and Gambi 2007, Westheide 2008, Di Domenico et al. 2014a, and Di Domenico et al. 2019 [51,53,250,251]. Di Domenico et al. [270] provided the most comprehensive and recent revision of the family.

Author Contributions: K.W., A.K. and A.M. conceptualized and edited the manuscript. K.W. and A.M. drafted the abstract and introduction. A.K. prepared the first draft and plates for the methods and Dinophilidae; A.M. for Protodrilidae and Protodriloididae, B.C.G. for Apharyngtidae; K.W. for Diurodrilidae, Nerillidae and Psammodrilidae; M.D.D. for Polygordiidae and Saccocirridae; and N.B. for Lobatocerebridae. All authors have read and agreed to the published version of the manuscript. 
Funding: This research received no external funding.

Institutional Review Board Statement: Not applicable.

Informed Consent Statement: Not applicable.

Data Availability Statement: Not applicable.

Acknowledgments: We greatly acknowledge our friends and family/colleagues and students that have joined our studies of these wonderful worms. We furthermore thank the following publishers for granting us permission to reuse, redraw, or copy selected images: CBM-Cahiers de Biologie Marine/Station Biologique de Roscoff; Javier González, Director of the Museo Nacional de Historia Natural from Montevideo; John Wiley \& Sons; Linnean Society London; and Springer Nature. Lastly, we are very grateful for the careful eyes and helpful advices of the anonymous reviewers.

Conflicts of Interest: The authors declare no conflict of interest. The funders had no role in the design of the study; in the collection, analyses, or interpretation of data; in the writing of the manuscript, or in the decision to publish the results.

\section{References}

1. Giere, O. Meiobenthology; Springer Science \& Business Media: Berlin/Heidelberg, Germany, 2013.

2. Schmidt-Rhaesa, A. (Ed.) Guide to the Identification of Marine Meiofauna; Dr. Friedrich Pfeil Verlag: Munich, Germany, 2020.

3. Worsaae, K. Annelida (excluding Clitellata and Sipuncula). In Guide to the Identification of Marine Meiofauna; Schmidt-Rhaesa, A., Ed.; Dr. Friedrich Pfeil Verlag: Munich, Germany, 2020; pp. 239-270.

4. Bunke, D. Aeolosomatidae and Potamodrilidae. In Introduction to the Study of Meiofauna; Higgins, R.P., Thiel, H., Eds.; Smithsonian Institution: Washington, DC, USA, 1988; pp. 345-348.

5. Hermans, C.O. The systematic position of the Archiannelida. Syst. Biol. 1969, 18, 85-102. [CrossRef]

6. Hatschek, B. Studien über die Entwicklungsgeschichte der Anneliden: Ein Beitrag zur Morphologie der Bilaterien. Arb. Zool. Inst. Univ. Wien. 1878, 1, 277-404.

7. Worsaae, K.; Kristensen, R.M. Evolution of interstitial Polychaeta (Annelida). Hydrobiologia 2005, 535/536, 319-340. [CrossRef]

8. Laumer, C.E.; Bekkouche, N.; Kerbl, A.; Goetz, F.; Neves, R.C.; Sørensen, M.V.; Kristensen, R.M.; Hejnol, A.; Dunn, C.W.; Giribet, G.; et al. Spiralian phylogeny informs the evolution of microscopic lineages. Curr. Biol. 2015, 25, 2000-2006. [CrossRef]

9. Helm, C.; Beckers, P.; Bartolomaeus, T.; Drukewitz, S.H.; Kourtesis, I.; Weigert, A.; Purschke, G.; Worsaae, K.; Struck, T.H.; Bleidorn, C. Convergent evolution of the ladder-like ventral nerve cord in Annelida. Front. Zool. 2018, 15, 36-17. [CrossRef] [PubMed]

10. Andrade, S.C.S.; Novo, M.; Kawauchi, G.Y.; Worsaae, K.; Pleijel, F.; Giribet, G.; Rouse, G.W. Articulating "Archiannelids": Phylogenomics and annelid relationships, with emphasis on meiofaunal taxa. Mol. Biol. Evol. 2015, 32, 2860-2875. [CrossRef] [PubMed]

11. Struck, T.H.; Golombek, A.; Weigert, A.; Franke, F.A.; Westheide, W.; Purschke, G.; Bleidorn, C.; Halanych, K.M. The evolution of annelids reveals two adaptive routes to the interstitial realm. Curr. Biol. 2015, 25, 1993-1999. [CrossRef] [PubMed]

12. Martín-Durán, J.M.; Vellutini, B.C.; Marletaz, F.; Cetrangolo, V.; Cvetesic, N.; Thiel, D.; Henriet, S.; Grau-Bové, X.; Carrillo-Baltodano, A.M.; Gu, W.; et al. Conservative route to extreme genome compaction in a miniature annelid. Nat. Ecol. Evol. 2020.

13. Chen, H.; Parry, L.A.; Vinther, J.; Zhai, D.; Hou, X.; Ma, X. A Cambrian crown annelid reconciles phylogenomics and the fossil record. Nature 2020, 583, 249-252. [CrossRef] [PubMed]

14. Worsaae, K.; Rouse, G.W. Is Diurodrilus an annelid? J. Morph. 2008, 269, 1426-1455. [CrossRef]

15. Kerbl, A.; Bekkouche, N.; Sterrer, W.; Worsaae, K. Detailed reconstruction of the nervous and muscular system of Lobatocerebridae with an evaluation of its annelid affinity. BMC Evol. Biol. 2015, 15, 277. [CrossRef] [PubMed]

16. Helm, C.; Vöcking, O.; Kourtesis, I.; Hausen, H. Owenia fusiformis-A basally branching annelid suitable for studying ancestral features of annelid neural development. BMC Evol. Biol. 2016, 16, 129. [CrossRef]

17. Müller, M.C. Polychaete nervous systems: Ground pattern and variations-cLS microscopy and the importance of novel characteristics in phylogenetic analysis. Integr. Comp. Biol. 2006, 46, 125-133. [CrossRef]

18. Miyamoto, N.; Shinozaki, A.; Fujiwara, Y. Neuroanatomy of the vestimentiferan tubeworm Lamellibrachia satsuma provides insights into the evolution of the polychaete nervous system. PLOS ONE 2013, 8, 1-9. [CrossRef]

19. Purschke, G. Male genital organs, spermatogenesis and spermatozoa in the enigmatic terrestrial polychaete Parergodrilus heideri (Annelida, Parergodrilidae). Zoomorphology 2002, 121, 125-138. [CrossRef]

20. Purschke, G. Comparative electron microscopic investigation of the nuchal organs in Protodriloides, Protodrilus, and Saccocirrus (Annelida, Polychaeta). Can. J. Zool. 1990, 68, 325-338. [CrossRef]

21. Worsaae, K.; Giribet, G.; Martínez, A. The role of progenesis in the diversification of the interstitial annelid lineage Psammodrilidae. Invertebr. Syst. 2018, 32, 774-793. [CrossRef]

22. Bleidorn, C. The role of character loss in phylogenetic reconstruction as exemplified for the Annelida. J. Zool. Syst. Evol. Res. 2007, 45, 299-307. [CrossRef] 
23. Mock, H. Zur Kenntnis von Diurodrilus subterraneus (Polychaeta, Dinophilidae) aus dem Sandhang der Nordseeinsel Sylt. Helgol. Meeresunters. 1981, 34, 329-335. [CrossRef]

24. Rieger, R.M.; Rieger, G.E. Fine structure of the archiannelid cuticle and remarks on the evolution of the cuticle within the Spiralia. Acta Zool. 1976, 57, 53-68. [CrossRef]

25. Worsaae, K.; Kristensen, R.M. Diurodrilidae Kristensen \& Niilonen, 1982. In Handbook of Zoology: Annelida; Purschke, G., Böggemann, M., Westheide, W., Eds.; De Gruyter: Berlin, Germany, 2020; Volume 3.

26. Worsaae, K.; Kerbl, A.; Vang, Á.; Gonzalez, B.C. Broad North Atlantic distribution of a meiobenthic annelid-Against all odds. Sci. Rep. 2019, 9, 15497-13. [CrossRef]

27. Gelder, S.R. A review of the zoogeography and habitat data of the genus Nerilla Schmidt, 1848 (Annelida: Archiannelida). J. Nat. Hist. 1974, 8, 631-643. [CrossRef]

28. Jouin, C. Recherches sur les Protodrilidae (Archiannélides). I. Étude morphologique et systématique du genre Protodrilus. Cah. Biol. Mar. 1970, 11, 367-434.

29. Di Domenico, M.; Martínez, A.; Almeida, T.C.M.; Martins, M.O.; Worsaae, K.; Lana, P.C. Response of the meiofaunal annelid Saccocirrus pussicus (Saccocirridae) to sandy beach morphodynamics. Hydrobiologia 2014, 734, 1-16. [CrossRef]

30. Sato-Okoshi, W.; Okoshi, K.; Fujiwara, Y. A new species of Protodrilus (Annelida, Protodrilidae), covering bone surfaces bright red, in whale-fall ecosystems in the northwest Pacific. Biol. Bull. 2015, 229, 209-219. [CrossRef] [PubMed]

31. Jouin, C. The ultrastructure of a gutless annelid, Parenterodrilus gen. nov. taenioides (=Astomus taenioides) (Polychaeta, Protodrilidae). Can. J. Zool. 1992, 70, 1833-1848. [CrossRef]

32. Worsaae, K. Systematics of Nerillidae (Polychaeta, Annelida). Meiofauna Marina 2005, 14, 49-74.

33. Worsaae, K.; Kristensen, R.M. A new species of Paranerilla (Polychaeta: Nerillidae) from Northeast Greenland Waters, Arctic Ocean. Cah. Biol. Mar. 2003, 44, 23-39.

34. Morselli, I.; Sarto, M.; Mari, M. Troglochaetus beranecki Delachaux (Annelida, Polychaeta): Collecting methods and microscopy techniques for SEM and in vivo observations. Hydrobiologia 1998, 379, 213-216. [CrossRef]

35. Sterrer, W.; Iliffe, T.M. Mesonerilla prospera, a new archiannelid from marine caves in Bermuda. Proc. Biol. Soc. Wash. 1982, 95, 509-514.

36. Worsaae, K.; Martinez, A.; Núñez, J. Nerillidae (Annelida) from the Corona lava tube, Lanzarote, with description of Meganerilla cesari n. sp. Mar. Biodivers. 2009, 39, 195-207. [CrossRef]

37. Worsaae, K.; Mikkelsen, M.D.; Martinez, A. Description of six new species of Mesonerilla (Nerillidae, Annelida) and an emended description of M. intermedia Wilke, 1953, from marine and cave environments. Mar. Biodivers. 2019, 49, 2141-2165. [CrossRef]

38. Worsaae, K.; Rouse, G.W. Mesonerilla neridae, n. sp. (Nerillidae): First meiofaunal annelid from deep-sea hydrothermal vents. Zoosymposia 2009, 2, 297-303. [CrossRef]

39. Müller, M.C.M.; Bernhard, J.M.; Jouin-Toulmond, C. A new member of Nerillidae (Annelida: Polychaeta), Xenonerilla bactericola gen. et sp. nov., collected off California, USA. Cah. Biol. Mar. 2001, 42, $203-217$.

40. Worsaae, K.; Sterrer, W.; Iliffe, T.M. Longipalpa saltatrix, a new genus and species of the meiofaunal family Nerillidae (Annelida: Polychaeta) from an anchialine cave in Bermuda. Proc. Biol. Soc. Wash. 2004, 117, 346-362.

41. Martinez, A.; Kvindebjerg, K.; Iliffe, T.M.; Worsaae, K. Evolution of cave suspension feeding in Protodrilidae (Annelida). Zool. Scr. 2017, 46, 214-226. [CrossRef]

42. Worsaae, K.; Gonzalez, B.C.; Kerbl, A.; Nielsen, S.H.; Jørgensen, J.T.; Armenteros, M.; Iliffe, T.M.; Martinez, A. Diversity and evolution of the stygobitic Speleonerilla nom. nov. (Nerillidae, Annelida) with description of three new species from anchialine caves in the Caribbean and Lanzarote. Mar. Biodivers. 2019, 49, 2167-2192. [CrossRef]

43. Cerca, J.; Meyer, C.; Stateczny, D.; Siemon, D.; Wegbrod, J.; Purschke, G.; Dimitrov, D.; Struck, T.H. Deceleration of morphological evolution in a cryptic species complex and its link to paleontological stasis. Evolution 2020, 74, 116-131. [CrossRef] [PubMed]

44. De Souza-Santos, L.P. An experimental approach to the ecophysiology of the interstitial polychaete Polygordius eschaturus (Annelida: Polygordiidae). Scimar 2017, 81, 509-515. [CrossRef]

45. Curini-Galletti, M.; Artois, T.; Delogu, V.; De Smet, W.H.; Fontaneto, D.; Jondelius, U.; Leasi, F.; Martinez, A.; Meyer-Wachsmuth, I.; Nilsson, K.S.; et al. Patterns of diversity in soft-bodied meiofauna: Dispersal ability and body size matter. PLoS ONE 2012, 7, e33801. [CrossRef]

46. Martinez, A.; Di Domenico, M.; Leasi, F.; Curini-Galletti, M.; Todaro, M.A.; Zotto, M.D.; Gobert, S.; Artois, T.; Norenburg, J.; Jörger, K.M.; et al. Patterns of diversity and endemism of soft-bodied meiofauna in an oceanic island, Lanzarote, Canary Islands. Mar. Biodivers. 2019, 49, 2033-2055. [CrossRef]

47. Tustison, C.A.; Ramey-Balci, P.A.; Rouse, G.W. More Knot Worms: Four new Polygordius (Annelida) species from the Pacific and Caribbean. Diversity 2020, 12, 146. [CrossRef]

48. Cerca, J.; Meyer, C.; Purschke, G.; Struck, T.H. Delimitation of cryptic species drastically reduces the geographical ranges of marine interstitial ghost-worms (Stygocapitella; Annelida, Sedentaria). Mol. Phylogenet. Evol. 2020, 143, 106663. [CrossRef] [PubMed]

49. Martinez, A.; Di Domenico, M.; Jörger, K.; Norenburg, J.; Worsaae, K. Description of three new species of Protodrilus (Annelida, Protodrilidae) from Central America. Mar. Biol. Res. 2013, 9, 676-691. [CrossRef]

50. Martinez, A.; Di Domenico, M.; Rouse, G.W.; Worsaae, K. Phylogeny and systematics of Protodrilidae (Annelida) inferred with total evidence analyses. Cladistics 2015, 31, 250-276. [CrossRef] 
51. Di Domenico, M.; Martínez, A.; Lana, P.C.; Worsaae, K. Molecular and morphological phylogeny of Saccocirridae (Annelida) reveals two cosmopolitan clades with specific habitat preferences. Mol. Phylogenet. Evol. 2014, 75, 202-218. [CrossRef]

52. Higgins, R.P.; Thiel, H. Introduction to the Study of Meiofauna, 1st ed.; Higgins, R.P., Thiel, H., Eds.; Smithsonian Institution: Washington, DC, USA, 1988.

53. Westheide, W. Polychaetes: Interstitial Families, 2nd ed.; Crothers, J.H., Ed.; The Linnean Society of London (Field Studies Council Shrewsbury): London, UK, 2008.

54. De Jonge, V.N.; Bouwman, L.A. A simple density separation technique for quantitative isolation of meiobenthos using the colloidal silica Ludox-TM. Mar. Biol. 1977, 42, 143-148. [CrossRef]

55. Yoder, M.; De Ley, I.T.; King, I.W.; Mundo-Ocampo, M.; Mann, J.; Blaxter, M.; Poiras, L.; De Ley, P. DESS: A versatile solution for preserving morphology and extractable DNA of nematodes. Nematology 2006, 8, 367-376. [CrossRef]

56. Raikova, O.I.; Meyer-Wachsmuth, I.; Jondelius, U. The plastic nervous system of Nemertodermatida. Org. Divers. Evol. 2016, 16, 85-104. [CrossRef]

57. Kalt, M.R.; Tandler, B. A study of fixation of early amphibian embryos for electron microscopy. J. Ultrastruct. Res. 1971, 36, 633-645. [CrossRef]

58. Cheng, P.C.; Walden, D.B.; Greyson, R.I. Improved plant microtechnique for TEM, SEM and LM specimen preparation. Natl. Sci. Counc. Month. Rep. China 1979, 7, 1000-1007.

59. Westheide, W.; Purschke, G. Organism processing. In Introduction to the Study of Meiofauna; Higgins, R.P., Thiel, H., Eds.; Smithsonian Institution: Washington, DC, USA, 1988; pp. 146-160.

60. Kerbl, A.; Vereide, E.H.; Gonzalez, B.C.; Rouse, G.W.; Worsaae, K. Two new meiofaunal species of Trilobodrilus (Dinophilidae, Annelida) from California, USA. Eur. J. Taxon. 2018, 421, 1-18. [CrossRef]

61. Worsaae, K.; Müller, M.C. Nephridial and gonoduct distribution patterns in Nerillidae (Annelida: Polychaeta) examined by tubulin staining and cLSM. J. Morphol. 2004, 261, 259-269. [CrossRef]

62. Jörger, K.M.; Norenburg, J.L.; Wilson, N.G.; Schrödl, M. Barcoding against a paradox? Combined molecular species delineations reveal multiple cryptic lineages in elusive meiofaunal sea slugs. BMC Evol. Biol. 2012, 12, 1-18. [CrossRef]

63. Meyer-Wachsmuth, I.; Curini-Galletti, M.; Jondelius, U. Hyper-cryptic marine meiofauna: Species complexes in Nemertodermatida. PLoS ONE 2014, 9, e107688. [CrossRef] [PubMed]

64. Fontaneto, D.; Flot, J.-F.; Tang, C.Q. Guidelines for DNA taxonomy, with a focus on the meiofauna. Mar. Biodivers. 2015, 45, 433-451. [CrossRef]

65. Fujisawa, T.; Barraclough, T.G. Delimiting Species Using Single-Locus Data and the Generalized Mixed Yule Coalescent Approach: A Revised Method and Evaluation on Simulated Data Sets. Syst. Biol. 2013, 62, 707-724. [CrossRef]

66. Kapli, P.; Lutteropp, S.; Zhang, J.; Kobert, K.; Pavlidis, P.; Stamatakis, A.; Flouri, T. Multi-rate Poisson tree processes for single-locus species delimitation under maximum likelihood and Markov chain Monte Carlo. Bioinformatics 2017, 33, 1630-1638. [CrossRef] [PubMed]

67. Zhang, J.; Kapli, P.; Pavlidis, P.; Stamatakis, A. A general species delimitation method with applications to phylogenetic placements. Bioinformatics 2013, 29, 2869-2876. [CrossRef]

68. Puillandre, N.; Lambert, A.; Brouillet, S.; Achaz, G. ABGD, Automatic Barcode Gap Discovery for primary species delimitation. Mol. Ecol. 2012, 21, 1864-1877. [CrossRef] [PubMed]

69. Eibye-Jacobsen, D.; Kristensen, R.M. A new genus and species of Dorvilleidae (Annelida, Polychaeta) from Bermuda, with a phylogenetic analysis of Dorvilleidae, Iphitimidae and Dinophilidae. Zool. Scr. 1994, 23, 107-131. [CrossRef]

70. Struck, T.H. Phylogeny. In Handbook of Zoology: Annelida; Purschke, G., Böggemann, M., Westheide, W., Eds.; De Gruyter: Berlin, Germany, 2019; Volume 1, pp. 37-68.

71. Westheide, W. Apharyngtus Westheide, 1971. In Handbook of Zoology: Annelida; Purschke, G., Böggemann, M., Westheide, W., Eds.; De Gruyter: Berlin, Germany, 2019; Volume 1, pp. 234-237.

72. Westheide, W. Apharyngtus punicus nov. gen. nov. spec., an aberrant archiannelid from the mesopsammal of the Tunesian Coast of the Mediterranean. Mikrofauna Meeresboden 1971, 6, 233-248.

73. Jumars, P.A.; Dorgan, K.M.; Lindsay, S.M. Diet of worms emended: An update of polychaete feeding guilds. Ann. Rev. Mar. Sci. 2015, 7, 497-520. [CrossRef] [PubMed]

74. Riser, N.W. General observations on the intertidal interstitial fauna of New Zealand. Tane 1984, 30, $239-249$.

75. Westheide, W. Dinophilidae Verrill, 1892. In Handbook of Zoology: Annelida; Purschke, G., Böggemann, M., Westheide, W., Eds.; De Gruyter: Berlin, Germany, 2019; Volume 1, pp. 217-233.

76. Struck, T.H.; Westheide, W.; Purschke, G. Progenesis in Eunicida ("Polychaeta," Annelida)—Separate evolutionary events? Evidence from molecular data. Mol. Phylogenet. Evol. 2002, 25, 190-199. [CrossRef]

77. Remane, A. Diagnosen neuer Archianneliden. Zool. Anz. 1925, 65, 15-17.

78. Kerbl, A.; Fofanova, E.G.; Mayorova, T.D.; Voronezhskaya, E.E.; Worsaae, K. Comparison of neuromuscular development in two dinophilid species (Annelida) suggests progenetic origin of Dinophilus gyrociliatus. Front. Zool. 2016, 13, 49. [CrossRef]

79. Kerbl, A.; Conzelmann, M.; Jekely, G.; Worsaae, K. High diversity in neuropeptide immunoreactivity patterns among three closely related species of Dinophilidae (Annelida). J. Comp. Neurol. 2017, 525, 3596-3635. [CrossRef]

80. Fofanova, E.G.; Mayorova, T.D.; Voronezhskaya, E.E. Paradoxical effect of serotonin on ciliary locomotion of the adult archiannelid worms. Zool. Bespozvon. 2017, 14, 114-120. 
81. Müller, M.C.M.; Westheide, W. Comparative analysis of the nervous systems in presumptive progenetic dinophilid and dorvilleid polychaetes (Annelida) by immunohistochemistry and cLSM. Acta Zool. 2002, 83, 33-48. [CrossRef]

82. Purschke, G.; Arendt, D.; Hausen, H.; Müller, M.C.M. Photoreceptor cells and eyes in Annelida. Arthropod Struct. Dev. 2006, 35, 211-230. [CrossRef] [PubMed]

83. Eakin, R.M.; Martin, G.G.; Reed, C.T. Evolutionary significance of fine structure of archiannelid eyes. Zoomorphology 1977, 88, 1-18. [CrossRef]

84. Kajihara, H.; Ikoma, M.; Yamasaki, H.; Hiruta, S.F. Trilobodrilus itoi sp. nov., with a re-description of T. nipponicus (Annelida: Dinophilidae) and a molecular phylogeny of the genus. Zool. Sci. 2015, 32, 405-417. [CrossRef]

85. Purschke, G. On the ground pattern of Annelida. Org. Divers. Evol. 2002, 2, 181-196. [CrossRef]

86. Fofanova, E.G.; Nezlin, L.P.; Voronezhskaya, E.E. Ciliary and nervous structures in juvenile females of the annelid Dinophilus gyrociliatus (O. Schmidt, 1848) (Annelida: Polychaeta). Russ. J. Mar. Biol. 2014, 40, 43-52. [CrossRef]

87. Moore, A. Dinophilus gardineri (sp. nov.). Biol. Bull. 1899, 1, 15-18. [CrossRef]

88. Kerbl, A.; Tolstrup, E.W.; Worsaae, K. Nerves innervating copulatory organs show common FMRFamide, FVRIamide, MIP and serotonin immunoreactivity patterns across Dinophilidae (Annelida) indicating their conserved role in copulatory behaviour. BMC Zool. 2019, 4, 8. [CrossRef]

89. Jennings, J.B.; Gelder, S.R. Feeding and digestion in Dinophilus gyrociliatus (Annelida: Archiannelida). J. Zool. 1969, 158, 441-451. [CrossRef]

90. Beniash, E.A.; Yerlikova, N.N.; Yevdonin, L.A. Some characteristics of the Dinophilus vorticoides anatomy of the nervous system. In Explorations of the Fauna of the Seas; Bushinskaya, G.N., Ed.; Russian Academy of Sciences: St. Petersburg, Russia, 1992; Volume 43, pp. 5-9.

91. Repiakhov, V.M. K anatomii i istorii razvitiia Dinophilus gyrociliatus, O. Schmidt. Zap. Novoross. Obshchestva Estestvoispyt. 1886, $77 \mathrm{p}$.

92. Mamkaev, Y.V. Dinophilida as a primitive group of Trochozoa. Investig. Mar. Fauna 1985, 34, 99-103.

93. Müller, M.C.M.; Westheide, W. Das Nervensystem parapodienloser Polychaeten: Orthogonale Strukturen des Nervensystems juveniler Stadien und progenetischer Arten. Verh. Dtsch. Zool. Ges. 1997, 90, 209.

94. Purschke, G. Annelida: Basal groups and Pleistoannelida. In Structure and Evolution of Invertebrate Nervous Systems; SchmidtRhaesa, A., Harzsch, S., Purschke, G., Eds.; Oxford University Press: Oxford, UK, 2015; pp. 254-312.

95. Kerbl, A.; Martín-Durán, J.M.; Worsaae, K.; Hejnol, A. Molecular regionalization in the compact brain of the meiofaunal annelid Dinophilus gyrociliatus (Dinophilidae). EvoDevo 2016, 7, 20. [CrossRef] [PubMed]

96. Fofanova, E.G.; Voronezhskaya, E.E. The structure of archiannelid Dinophilus gyrociliatus ventral nerve cords. Acta Biol. Hung. 2012, 63, 88-90. [CrossRef]

97. Jägersten, G. Zur Kenntnis der Morphologie, Enzystierung und Taxonomie von Dinophilus. Kungl. Svenska Vetenskapsakad. Handl. 1944, 21, 1-50.

98. Jennings, J.B.; Donworth, P.J. Observations on the life cycle and nutrition of Dinophilus taeniatus Harmer 1889 (Annelida: Polychaeta). Ophelia 1986, 25, 119-137. [CrossRef]

99. Jägersten, G. Life cycle of Dinophilus, with special reference to the encystment and its dependence on temperature. Oikos 1951, 3, 143-165. [CrossRef]

100. Donworth, P.J. A reappraisal and validation of the species Dinophilus taeniatus Harmer 1889 and of taxonomically significant features in monomorphic dinophilids (Annelida: Polychaeta). Zool. Anz. 1985, 216, 32-38.

101. Windoffer, R.; Westheide, W. The nervous system of the male Dinophilus gyrociliatus (Annelida: Polychaeta). I. Number, types and distribution pattern of sensory cells. Acta Zool. 1988, 69, 55-64. [CrossRef]

102. Windoffer, R.; Westheide, W. The nervous system of the male Dinophilus gyrociliatus (Polychaeta, Dinophilidae): II. Electron microscopical reconstruction of nervous anatomy and effector cells. J. Comp. Neurol. 1988, 272, 475-488. [CrossRef]

103. Fauvel, P. Polychètes sédentaires. Addenda aux errantes, Arachniannélides, Myzostomaires. In Faune de France; Volume 16, Paul Lechevalier: Paris, France, 1927.

104. Jones, E.R.; Ferguson, F.F. The genus Dinophilus (Archiannelida) in the United States. Am. Midl. Nat. 1957, 57, 440-449. [CrossRef]

105. Ax, P. Das Fortpflanzungsverhalten von Trilobodrilus (Archiannelida, Dinophilidae). Mar. Biol. 1968, 1, 330-335. [CrossRef]

106. Harmer, S.F. Notes on the anatomy of Dinophilus. Proc. Cambridge Philos. Soc. 1889, 6, 119-143. [CrossRef]

107. Westheide, W. Die Gattung Trilobodrilus (Archiannelida, Polychaeta) von der deutschen Nordseeküste. Helgol. Meeresunters. 1967, 16, 207-215. [CrossRef]

108. Du Bois-Reymond Marcus, E. Further archiannelids from Brazil. Com. Zool. Mus. 1948, 48, 1-17.

109. Westheide, W.; Nordheim, H. Interstitial Dorvilleidae (Annelida, Polychaeta) from Europe, Australia and New Zealand. Zool. Scr. 1985, 14, 183-199. [CrossRef]

110. Kristensen, R.M.; Niilonen, T. Structural Studies on Diurodrilus Remane (Diurodrilidae fam.n.), with description of Diurodrilus westheidei sp.n. from the Arctic Interstitial Meiobenthos, W. Greenland. Zool. Scr. 1982, 11, 1-12. [CrossRef]

111. Westheide, W. The systematic position of the Dinophilidae and the archiannelid problem. In The Origins and Relationships of Lower Invertebrates; Conway Morris, S., George, J.D., Gibson, R., Platt, H.M., Eds.; Systematic Association: Oxford, UK, 1985; Volume 28, pp. 310-326. 
112. Golombek, A.; Tobergte, S.; Nesnidal, M.P.; Purschke, G.; Struck, T.H. Mitochondrial genomes to the rescue-Diurodrilidae in the myzostomid trap. Mol. Phylogenet. Evol. 2013, 68, 312-326. [CrossRef] [PubMed]

113. Kajihara, H.; Ikoma, M.; Yamasaki, H.; Hiruta, S.F. Diurodrilus kunii sp. nov. (Annelida: Diurodrilidae) and a molecular phylogeny of the genus. Zool. Sci. 2019, 36, 250-258. [CrossRef] [PubMed]

114. Kristensen, R.M.; Eibye-Jacobsen, D. Ultrastructure of spermiogenesis and spermatozoa in Diurodrilus subterraneus (Polychaeta, Diurodrilidae). Zoomorphology 1995, 115, 117-132. [CrossRef]

115. Schmidt, P.; Westheide, W. Interstitielle Fauna von Galàpagos. XVII. Polygordiidae, Saccocirridae, Protodrilidae, Nerillidae, Dinophilidae (Polychaeta). Mikrofauna Meeresbod. 1977, 62, 1-38.

116. Paxton, H. Family Diurodrilidae. In Polychaetes \& Allies: The Southern Synthesis; Beesley, P.L., Ross, G.J.B., Glasby, C.J., Eds.; Csiro Publishing: Clayton, Australia, 2000; pp. 104-105.

117. Villora-Moreno, S. Diurodrilus benazzi Gerlach, 1952 (Diurodrilida) and Dinophilus gyrociliatus O. Schmidt, 1857 (Dinophilida): First record of two orders of interstitial polychaetes on the Iberian Peninsula. Oceanogr. Lit. Rev. 1998, 7, 1186.

118. Rieger, R.M. A new group of interstitial worms, Lobatocerebridae nov. fam. (Annelida) and its significance for metazoan phylogeny. Zoomorphology 1980, 95, 41-84. [CrossRef]

119. Kerbl, A.; Worsaae, K. Lobatocerebridae Rieger, 1980. In Handbook of Zoology: Annelida; Purschke, G., Böggemann, M., Westheide, W., Eds.; De Gruyter: Berlin, Germany, 2019; Volume 1, pp. 201-216.

120. Haszprunar, G.; Rieger, R.M.; Schuchert, P. Extant "problematica" within or near the Metazoa. In The Early Evolution of Metazoa and the Significance of Problematic Taxa; Simonetta, A.M., Conway Morris, S., Eds.; Cambridge University Press: Cambridge, UK, 1991; pp. 99-105.

121. Zrzavý, J. Gastrotricha and metazoan phylogeny. Zool. Scr. 2003, 32, 61-81. [CrossRef]

122. Rieger, R.M. Comparative ultrastructure and the Lobatocerebridae: Keys to understand the phylogenetic relationship of Annelida and the acoelomates. In The Ultrastructure of Polychaeta; Westheide, W., Hermans, C.O., Eds.; John Wiley \& Sons: Stuttgart, Germany, 1988; Volume 4, pp. 373-382.

123. Tzetlin, A.B.; Filippova, A.V. Muscular system in polychaetes (Annelida). Hydrobiologia 2005, 535/536, 113-126. [CrossRef]

124. Rieger, R.M. Fine structure of the body wall, nervous system, and digestive tract in the Lobatocerebridae Rieger and the organization of the gliointerstitial system in Annelida. J. Morph. 1981, 167, 139-165. [CrossRef]

125. Rieger, R.M. Neue Organisationstypen aus der Sandlückenraumfauna: Die Lobatocerebriden und Jennaria pulchra. Verh. Dtsch. Zool. Ges. 1991, 84, 247-259.

126. Westheide, W. Progenesis as a principle in meiofauna evolution. J. Nat. Hist. 1987, 21, 843-854. [CrossRef]

127. Westheide, W.; Purschke, G. Leptonerilla diplocirrata, a new genus and species of interstitial polychaetes from the island of Hainan, south China (Nerillidae). Proc. Biol. Soc. Wash. 1996, 109, 586-590.

128. Worsaae, K.; Nygren, A.; Rouse, G.W.; Giribet, G.; Persson, J.; Sundberg, P.; Pleijel, F. Phylogenetic position of Nerillidae and Aberrantia (Polychaeta, Annelida), analyzed by direct optimization of combined molecular and morphological data. Zool. Scr. 2005, 34, 313-328. [CrossRef]

129. Boaden, P.J.S. Meganerilla swedmarki, nov. gen., nov. spec., an archiannelid of the family Nerillidae. Arkiv Zool. 1961, 13, 553-559.

130. Ax, P. Thalassochaetus palpifoliaceus nov. gen., nov. spec. (Archiannelida, Nerillidae), ein marine Verwandter von Troglochaetus beranecki Delachaux. Zool. Anz. 1954, 153, 64-75.

131. Tzetlin, A.B.; Saphonov, M.V. Trochonerilla mobilis gen. et sp. n., a meiofaunal nerillid (Annelida, Polychaeta) from a marine aquarium in Moscow. Zool. Scr. 1992, 21, 251-254. [CrossRef]

132. Delachaux, T. Un polychète d'eau douce cavernicole: Troglochaetus beranecki nov. gen. nov. spec. Bull. Soc. Neuchatel. Sci. Nat. 1921, 45, 1-11.

133. Müller, M.C.M. Aristonerilla: A new genus (Annelida: Polychaeta) with description of Aristonerilla (Micronerilla) brevis comb. nov. from a seawater aquarium. Cah. Biol. Mar. 2002, 43, 131-139.

134. Kirsteuer, E. Zur Kenntnis der Archianneliden des Roten Meeres. Zool. Anz. 1966, 177, 288-296.

135. Worsaae, K. Nerillidae Levinsen, 1883. In Handbook of Zoology: Annelida; Purschke, G., Böggemann, M., Westheide, W., Eds.; De Gruyter: Berlin, Germany, 2020; Volume 3.

136. Müller, M.C.M.; Worsaae, K. CLSM analysis of the phalloidin-stained muscle system in Nerilla antennata, Nerillidium sp. and Trochonerilla mobilis (Polychaeta; Nerillidae). J. Morph. 2006, 267, 885-896. [CrossRef] [PubMed]

137. Purschke, G. Ultrastructure of nuchal organs in polychaetes (Annelida)—New results and review. Acta Zool. 1997, 78, 123-143. [CrossRef]

138. Gelder, S.R.; Uglow, R.F. Feeding and gut structure in Nerilla antennata (Annelida: Archiannelida). J. Zool. 1973, 171, $225-237$. [CrossRef]

139. Purschke, G. Anatomy and ultrastructure of ventral pharyngeal organs and their phylogenetic importance in Polychaeta (Annelida). Zoomorphology 1985, 105, 223-239. [CrossRef]

140. Tzetlin, A.B.; Zarvarzina, E.G.; Saphonov, M.V. Functional morphological analysis of the pharynx in some annelids. Dokl. Akad. Nauk SSSR 1987, 294, 1008-1011.

141. Tzetlin, A.B.; Purschke, G.; Westheide, W.; Saphonov, M.V. Ultrastructure of enteronephridia and general description of the alimentary canal in Trochonerilla mobilis and Nerillidium troglochaetoides (Polychaeta, Nerillidae). Acta Zool. 1992, 73, 163-176. [CrossRef] 
142. Worsaae, K. Functional morphology of two mud-dwelling meiofana polychaetes of the family Nerillidae (Annelida). In Arctic Biology Field Course, Qeqertarsuaq; University of Copenhagen: Copenhagen, Denmark, 2002; pp. 119-128.

143. Müller, M.C.M. Das Nervensystem der Polychaeten Untersuchungen an ausgewählten taxa. Ph.D. Thesis, University of Osnabrück, Osnabrück, Germany, 1999; pp. 1-207.

144. Jouin, C. Sexualité et biologie de la reproduction chez Mesonerilla Remane et Meganerilla Boaden. Cah. Biol. Mar. 1968, 9, 31-52.

145. Magagnini, G. Reproduction in Nerilla antennata O. Schmidt (Archiannelida Nerillidae): Induction of spawning. Boll. Zool. 1982, 49, 283-286. [CrossRef]

146. Fransen, M.E. Fine structure of the brooding apparatus of the archiannelid Mesonerilla intermedia: Maternal connections to brooded eggs. Trans. Am. Microsc. Soc. 1983, 102, 25. [CrossRef]

147. Jouin, C. Mesonerilla biantennata n. sp. nouvelle archiannélide Nerillidae de la region de Roscoff. C. R. Acad. Sci. 1963, 257, 4057-4060.

148. Jouin, C. Hermaphrodisme chez Nerillidopsis hyalina n. g., n. sp. et chez Nerillidium Remane, Archiannélides. C. R. Acad. Sci. 1966, $263,412-415$.

149. Jouin, C. Sexualité chez Meganerilla Boaden et Mesonerilla Remane (Archiannélides Nerillidae) et modalités de reproduction chez ce dernier genre. C. R. Acad. Sci. 1967, 265, 150-153.

150. Jouin, C. Étude morphologique et anatomique de Nerillidopsis hyalina Jouin et de quelques Nerillidium Remane (Archiannelides Nerillidae). Arch. Zool. Exp. Gen. 1967, 108, 97-110.

151. Jouin, C. Nouvelles données sur Troglochaetus beranecki Delachaux (Archiannelida Nerillidae). Ann. Spéliol. 1973, $28,575-579$.

152. Jouin, C.; Swedmark, B. Paranerilla limicola n. g., n. sp., Archiannélide Nerillidae du benthos vaseux marin. Cah. Biol. Mar. 1965, 6, 201-218.

153. Goodrich, E.S. Nerilla an archiannelid. Quart. Journ. Micr. Sci. 1912, 57, 397-425.

154. Pennak, R.W. A fresh-water archiannelid from the Colorado Rocky Mountains. Trans. Am. Microsc. Soc. 1971, 90, 372-375. [CrossRef]

155. Pennak, R.W.; Ward, J.V. Interstitial faunal communities of the hyporheic and adjacent groundwater biotopes of a Colorado mountain stream. Arch. Hydrobiol. 1986, 74, 356-396.

156. Särkkä, J.; Mäkelä, J. Troglochaetus beranecki Delachaux (Polychaeta, Archiannelida) in esker groundwaters of Finland: A new class of limnic animals for northern Europe. Hydrobiologia 1998, 379, 17-21. [CrossRef]

157. Schmidt, H.; Westheide, W. RAPD-PCR experiments confirm the distinction between three morphologically similar species of Nerilla (Polychaeta: Nerillidae). Zool. Anz. 1998, 236, 277-285.

158. Worsaae, K. Phylogeny of Nerillidae (Polychaeta, Annelida) as inferred from combined $18 \mathrm{~S}$ rDNA and morphological data. Cladistics 2005, 21, 143-162. [CrossRef]

159. Lovén, S. Observations on the Metamorphosis of an Annelide. Ann. Mag. Nat. 1843, 111, 43-45. [CrossRef]

160. Agassiz, A. On the young stages of a few annelids. Ann. Mag. Nat. Hist. 1867, 19, 203-218. [CrossRef]

161. Schneider, A. Monographie der Nematoden; Georg Reimer: Berlin, Germany, 1866.

162. Schneider, A. Über Bau und Entwicklung von Polygordius. Arch. Anat. Physiol. Wiss. Med. 1868, 51-60.

163. Ramey-Balc1, P.; Fiege, D.; Struck, T.H. Molecular phylogeny, morphology, and distribution of Polygordius (Polychaeta: Polygordiidae) in the Atlantic and Mediterranean. Mol. Phylogenet. Evol. 2018, 127, 919-930. [CrossRef]

164. Ramey-Balci, P.A.; Fiege, D.; Purschke, G. Polygordiidae Czerniavsky, 1881. In Handbook of Zoology: Annelida, V; Purschke, G., Böggemann, M., Westheide, W., Eds.; De Gruyter: Berlin, Germany, 2020; Volume 3.

165. Ramey, P.A.; Fiege, D.; Leander, B.S. A new species of Polygordius (Polychaeta: Polygordiidae): From the inner continental shelf and in bays and harbours of the north-eastern United States. J. Mar. Biol. Assoc. UK 2006, 86, 1025-1034. [CrossRef]

166. Wilkens, V.; Purschke, G. Central nervous system and sense organs, with special reference to photoreceptor-like sensory elements, in Polygordius appendiculatus (Annelida), an interstitial polychaete with uncertain phylogenetic affinities. Invertebr. Biol. 2009, 128, 46-64. [CrossRef]

167. Rouse, G.W.; Fauchald, K. Cladistics and polychaetes. Zool. Scr. 1997, 26, 139-204. [CrossRef]

168. Rota, E.; Carchini, G. A new Polygordius (Annelida: Polychaeta) from the Terra Nova Bay, Ross Sea, Antarctica. Polar Biol. 1999, 21, 201-213. [CrossRef]

169. Avery, L.; Ramey, P.A.; Wilson, R.S. New Polygordiidae (Polychaeta) from the Australian region. Zootaxa 2009, 2068 , 59-68. [CrossRef]

170. Jamieson, B.G.M.; Rouse, G.W. The spermatozoa of the polychaeta (annelida): An ultrastructural review. Biol. Rev. 1989, 64, 93-157. [CrossRef]

171. Grassle, J.F.; Ramey, P.A.; Petrecca, R.F. Temporal and spatial variation in infaunal community structure in physically active continental shelf sediments at a long-term ecosystem observatory (LEO-15) off New Jersey, USA. J. Mar. Res. 2009, 67, 869-897. [CrossRef]

172. Ramey, P.A. Life history and population dynamics of a dominant polychaete, Polygordius jouinae, in inner continental shelf sands of the Mid-Atlantic Bight, USA. Mar. Biol. 2008, 154, 443-452. [CrossRef]

173. Ramey, P.A.; Bodnar, E. Selection by a deposit-feeding polychaete, Polygordius jouinae, for sands with relatively high organic content. Limnol. Oceanogr. 2008, 54, 1512-1520. [CrossRef] 
174. Martínez, A.; Purschke, G.; Worsaae, K. Protodrilidae Hatschek, 1888. In Handbook of Zoology: Annelida; Purschke, G., Böggemann, M., Westheide, W., Eds.; De Gruyter: Berlin, Germany, 2020; Volume 3.

175. Zrzavý, J.; Říha, P.; Piálek, L.; Janouškovec, J. Phylogeny of Annelida (Lophotrochozoa): Total-evidence analysis of morphology and six genes. BMC Evol. Biol. 2009, 9, 1-14. [CrossRef]

176. Czerniavsky, V. Materialia ad Zoographiam Ponticam comparatam Fasc. III. Vermes. Bull. Soc. Nat. Moscou 1881, 55, $213-334$.

177. Hatschek, B. Protodrilus leuckartii. Eine neue Gattung Archianneliden. Arb. Zool. Inst. Univ. Wien. 1881, 3, 79-92.

178. Hatschek, B. Lehrbuch der Zoologie: Eine Morphologische Übersicht des Thierreiches zur Einführung in das Studium Dieser Wissenschaft; Gustav Fischer: Jena, Germany, 1888.

179. Uljanina, V.N. Observations on Polygordius living in Sevastopol Bay (In Russian). Bull. Soc. Nat. Moscou 1877, $52,53-96$.

180. Purschke, G. Structure of the prostomial appendages and the central nervous system in the Protodrilida (Polychaeta). Zoomorphology 1993, 113, 1-20. [CrossRef]

181. Lam, H.J. Über den Bau und die Verwandschaft der Protoannelis meyeri, nov. gen., nov. spec., eine neue Archiannelide. Tijdschr. Nederl. Dierk. Ver. 1922, 18, 44-84.

182. Jouin, C. Description of a free-living Polychaete without gut: Astomus taenioides n.gen., n.sp. (Protodrilidae, Archiannelida). Can. J. Zool. 1979, 57, 2448-2456. [CrossRef]

183. Jouin-Toulmond, C.; Purschke, G. Ultrastructure of the spermatozoa of Parenterodrilus taenioides (Protodrilida: "Polychaeta") and its phylogenetic significance. Zoomorphology 2004, 123, 139-146. [CrossRef]

184. Jägersten, G. On the locomotion and attachment of Protodrilus: With remarks on the function of locomotory cilia. Zool. Bidr. Fran Upps. 1954, 31, 315-320.

185. Martin, G.G. Ciliary gliding in lower invertebrates. Zoomorphology 1978, 91, 249-261. [CrossRef]

186. Von Nordheim, H. Six new species of Protodrilus (Annelida, Polychaeta) from Europe and New Zealand, with a concise presentation of the genus. Zool. Scr. 1989, 18, 245-268. [CrossRef]

187. Jouin, C. Anatomical and ultrastructural study of the pharyngeal bulb in Protodrilus (Polychaeta, Archiannelida). I. Muscles and myo-epithelial junctions. Tissue Cell 1978, 10, 269-287. [CrossRef]

188. Jouin, C. Anatomical and ultrastructural study of the pharyngeal bulb in Protodrilus (Polychaeta, Archiannelida) II. The stomodeal and its cuticle. Tissue Cell 1978, 10, 289-301. [CrossRef]

189. Pierantoni, U. Genus Protodrilus. Fauna Flora Golf. Neapel. 1908, 31, 1-226.

190. Pierantoni, U. Organi genitali e glandole salivari nei Protodrili. Boll. Soc. Nat. Napoli 1906, 20, $154-157$.

191. Jägersten, G. Zur Kenntnis der äusseren Morphologie, Entwicklung und Ökologie von Protodrilus rubropharyngeus n. sp. Ark. Zool. 1940, 32A, 1-19.

192. Jägersten, G. Studies on the morphology, larval development and biology of Protodrilus. Zool. Bidr. Fran Upps. 1952, $29,427-511$.

193. Von Nordheim, H. Vergleichende Ultrastrukturuntersuchungen der Eu-und Paraspermien von 13 Protodrilus-Arten (Polychaeta, Annelida) und ihre taxonomische und phylogenetische Bedeutung. Helgol. Meeresunters. 1989, 43, 113-156. [CrossRef]

194. Von Nordheim, H. Ultrastructure and functional morphology of the female reproductive organs in Protodrilus (Polychaeta, Annelida). Helgol. Meeresunters. 1991, 45, 465-485. [CrossRef]

195. Von Nordheim, H. Ultrastructure and functional morphology of male genital organs and spermatophore formation in Protodrilus (Polychaeta, Annelida). Zoomorphology 1991, 111, 81-94. [CrossRef]

196. Bailey-Brock, J.H.; Jouin-Toulmond, C.; Brock, R.E. Protodrilidae (Annelida: Polychaeta) from the Hawaiian Islands and Comparison with Specimens from French Polynesia. Pac. Sci. 2010, 64, 463-472. [CrossRef]

197. Kirsteuer, E. Bredin-Archbold-Smithsonian Biological Survey of Dominica, 3: Marine Archiannelids from Dominica. Proc. U. S. Natl. Mus. 1967, 123, 1-6. [CrossRef]

198. Pierantoni, U. Sopra un nuovo Protodrilus a'acqua dolce. Monit. Zool. Ital. 1903, 14, 324-327.

199. Von Nordheim, H. Life histories of subtidal interstitial polychaetes of the families Polygordiidae, Protodrilidae, Nerillidae, Dinophilidae and Diurodrilidae from Helgoland (North Sea). Helgol. Meeresunters. 1984, 38, 1-20.

200. Di Domenico, M.; Martinez, A.; da Cunha Lana, P.; Worsaae, K. Protodrilus (Protodrilidae, Annelida) from the southern and southeastern Brazilian coasts. Helgol. Meeresunters. 2013, 67, 733-748. [CrossRef]

201. Kopiy, V. Some aspects of the biology and the present state of the population of Protodrilus flavocapitatus (Polychaeta: Protodrilidae) in the coastal zone of Crimea (the Black Sea). J. Black Sea Medit. Envirn. 2013, 19, 162-168.

202. Martinez, A.; Eckert, E.M.; Artois, T.; Careddu, G.; Casu, M.; Curini-Galletti, M.; Gazale, V.; Gobert, S.; Ivanenko, V.N.; Jondelius, U.; et al. Human access impacts biodiversity of microscopic animals in sandy beaches. Commun. Biol. 2020, 3, 1-9. [CrossRef]

203. Lagos, A.M.; Leon, M.V.; Quiroga, S.Y.; Martinez, A.; Lagos, A.M.; Leon, M.V.; Quiroga, S.Y. Interstitial annelids from the Caribbean Coast of Colombia. Rev. Biol. Trop. 2018, 66, 658-673. [CrossRef]

204. Martinez, A.; Gonzalez, B.C. Volcanic Anchialine Habitats of Lanzarote. In Cave Ecology; Analysis and Synthesis; Springer: Cham, Switzerland, 2018; Volume 235, pp. 399-414.

205. Martinez, A.; Gonzalez, B.C.; Worsaae, K.; Wilkens, H.; Núñez, J.; Oromi, P.; Iliffe, T.M. Guide to the Anchialine Ecosystems of Túnel de la Atlántida; Medio Ambiente, Cabilde de Lanzarote: Lanzarote, Spain, 2016.

206. Braby, C.E.; Rouse, G.W.; Johnson, S.B.; Jones, W.J.; Vrijenhoek, R.C. Bathymetric and temporal variation among Osedax boneworms and associated megafauna on whale-falls in Monterey Bay, California. Deep Sea Res. Part I Oceanogr. Res. Pap. 2007, 54, 1773-1791. [CrossRef] 
207. Langerhans, P. Über einige kanarische Anneliden. Nov. Act. Leop. 1881, 42, 93-124.

208. Armenante, Z. Protodrilus hypoleucus n. sp. Monit. Zool. Ital. 1903, 14, 221-222.

209. Jägersten, G. Die Abhängigkeit der Metamorphose vom Substrat des Biotops bei Protodrilus. Ark. Zool. 1940, 32, 1-12.

210. Aiyar, G.; Alikunhi, K.H. On some archiannelids of the Madras coast. Proc. Indian Acad. Sci. Sect. B 1943, 67, 113-140.

211. Alikunhi, K.H. On some archiannelids of the Krusadai Island. Proc. Nat. Inst. Sci. India 1948, 14, $373-383$.

212. Wieser, W. Archiannelids from the intertidal of Puget Sound. Trans. Am. Microsc. Soc. 1957, 76, 275-285. [CrossRef]

213. Jouin, C. Archiannélides Interstitielles de Nouvelle-Caledónie. Expédition Francaise sur les Récifs Coralliens de la Nouvelle-Calédonie 1970, 4, 147-167.

214. Von Nordheim, H. Systematics and ecology of Protodrilus helgolandicus sp.n., an Interstitial polychaete (Protodrilidae) from subtidal sands off Helgoland, German Bight. Zool. Scr. 1983, 12, 171-177. [CrossRef]

215. Giard, M.A. Sur une faunule caractéristique des sables a diatomées d'ambleteuse (Pas-de-Calais). C. R. Seances Soc. Biol. Fil. 1904, 56, 295-298.

216. Remane, A. Protodrilidae aus Ost- und Nordsee. Zool. Anz. 1926, 67, 119-125.

217. Purschke, G.; Jouin, C. Anatomy and ultrastructure of the ventral pharyngeal organs of Saccocirrus and Protodriloides with remarks on the phylogenetic relationships within the Protodrilida (Annelida: Polychaeta). J. Zool. 1988, 215, 405-432. [CrossRef]

218. Jouin, C. Morphologie et anatomie comparee de Protodrilus chaetifer Remane et Protodrilus symbioticus Giard; creation du nouveau genre Protodriloides (Archiannelides). Cah. Biol. Mar. 1966, 7, 139-155.

219. Purschke, G.; Müller, M.C.M. Structure of prostomial photoreceptor-like sense organs in Protodriloides species (Polychaeta, Protodrilida). Cah. Biol. Mar. 1996, 37, 205-219.

220. Martínez, A.; Worsaae, K.; Purschke, G. Protodriloididae Purschke \& Jouin, 1988. In Handbook of Zoology; Annelida; Purschke, G., Böggemann, M., Westheide, W., Eds.; De Gruyter: Berlin, Germany, 2020; Volume 3.

221. Fransen, M.E. Ultrastructure of coelomic organization in annelids I. Archiannelids and other small polychaetes. Zoomorphology 1980, 95, 235-249. [CrossRef]

222. Swedmark, B. Étude du développement larvaire et remarques sur la morphologie de Protodrilus symbioticus Giard (Archiannelides). Ark. Zool. 1954, 6, 511-522.

223. Gray, J.S. The behaviour of Protodrilus symbioticus (Giard) in temperature gradients. J. Anim. Ecol. 1965, 34, 455-461. [CrossRef]

224. Gray, J.S. Factors controlling the localizations of populations of Protodrilus symbioticus Giard. J. Anim. Ecol. 1966, $35,435$. [CrossRef]

225. Gray, J.S. The response of Protodrilus symbioticus (Giard) (Archiannelida) to light. J. Anim. Ecol. 1966, 35, 55-64. [CrossRef]

226. Sterrer, W. Paranerilla limicola Jouin \& Swedmark (Archiannelida) von der Norwegischen und Adriatischen Küste. Sarsia 2011, 36, 65-68.

227. Boaden, P.J.S. Soft meiofauna of sand from the Delta region of the Rhine, Meuse and Scheldt. Neth. J. Sea Res. 1976, 10, 461-471. [CrossRef]

228. Besteiro, C.; Eugénio, W.; Carvalho, L.H.; Veiga, P.; Rubal, M. Contributions to the autoecology and biogeography of some psammic species of Annelida Polychaeta from Galicia (North-West Iberian Peninsula). Cah. Biol. Mar. 2016, 57, 253-259.

229. Hamond, R. The non-polychaetous annelids of Norfolk, England, with additional notes on polychaetes. Cah. Biol. Mar. 1972, 13, 341-350.

230. Westheide, W. La faune des polychètes et des archiannelides dans les plages sableuses a ressac de la cote Méditerranéenne de la Tunisie. Bull. Inst. Oceanogr. Peche 1972, 2, 449-468.

231. Boaden, P.J.S. 1962 Colonization of graded sand by an interstitial fauna. Cah. Biol. Mar. 1962, 3, $245-248$.

232. Jouin, C. Le développement larvaire de Protodrilus chaetifer Remane (Archiannelida). C. R. Acad. Sci. Paris 1962, $255,3065-3067$.

233. Bellan, G. Remarques au sujet de la faune annélidienne "épibiote mobile" de quelques biotopes marins des côtes de Provence. Rapp. Proc. Verb. Réun. 1965, 18, 93-98.

234. Renaud-Debyser, J. Note sur la faune interstitielle du bassin d"Arcachon et description d"un gastrotriche nouveau. Cah. Biol. Mar. 1964, 5, 111-123.

235. Westheide, W. Zur Polychaetenfauna des Eulitorals der Nordseeinsel Sylt. Helgol. Meeresunters. 1966, 13, 203-209. [CrossRef]

236. Kristensen, R.M.; Nørrevang, A. Description of Psammodrilus aedificator sp.n. (Polychaeta), with notes on the Arctic Interstitial Fauna of Disko Island, W. Greenland. Zool. Scr. 1982, 11, 265-279. [CrossRef]

237. Mastepanova, E.A. Interstitial polychaetes of the seas of Russia. Zool. Bespozvon. 2004, 1, 59-64.

238. Priyalakshmi, G.; Menon, N.R. Sediment transport and bioinvasion-Possible impact of Tsunami-Protodriloides chaetifer an example. J. Mar. Biol. Ass. India 2007, 49, 86-88.

239. Swedmark, B. Psammodriloides fauveli n. gen. n. sp. et la famille des Psammodrilidae (Polychaeta, Sedentaria). Arkiv. Zool. 1958, 2, $55-65$.

240. Bartolomaeus, T.; Meyer, K. Development and phylogenetic significance of hooked setae in Arenicolidae (Polychaeta, Annelida). Invertebr. Biol. 1997, 116, 227. [CrossRef]

241. Rouse, G.; Pleijel, F. Polychaetes; Oxford Univdersity Press: Oxford, UK, 2001.

242. Parry, L.A.; Edgecombe, G.D.; Eibye-Jacobsen, D.; Vinther, J. The impact of fossil data on annelid phylogeny inferred from discrete morphological characters. Proc. R. Soc. B 2016, 283, 20161378-9. [CrossRef] 
243. Worsaae, K.; Sterrer, W. Description of two new interstitial species of Psammodrilidae (Annelida) from Bermuda. Mar. Biol. Res. 2006, 2, 431-445. [CrossRef]

244. Worsaae, K.; Kvindebjerg, K.; Martinez, A. Morphology of a new interstitial Psammodrilus (Psammodrilidae, Annelida) from Sardinia, Italy. Zool. Anz. 2015, 259, 13-21. [CrossRef]

245. Worsaae, K. Psammodrilidae Swedmark, 1952. In Handbook of Zoology; Purschke, G., Böggemann, M., Westheide, W., Eds.; De Gruyter: Berlin, Germany, 2019; pp. 143-155.

246. Swedmark, B. Recherches sur la morphologie le developpement et la biologie de Psammodrilus balanoglossoides, polychète sedentaire de la microfaune des sables. Arch. Zool. Exp. Gén. 1955, 92, 141-220.

247. Tzetlin, A.B.; Saphonov, M.V. Interstitial polychaetes (Annelida) from the Kandalaksha Bay of the White Sea. Zool. Zhurnal. 2002, 81, 899-908.

248. Brown, R. Saccocirridae (Annelida: Archiannelida) from the central coast of New South Wales. Austr. J. Mar. Freshw. Res. 1981, 32, 439-456. [CrossRef]

249. Purschke, G. Ultrastructural investigation of presumed photoreceptive organs in two Saccocirrus species (Polychaeta, Saccocirridae). J. Morphol. 1992, 211, 7-21. [CrossRef] [PubMed]

250. Jouin-Toulmond, C.; Gambi, C. Description of Saccocirrus goodrichi sp. nov. (Annelida: Polychaeta: Saccocirridae), a new Mediterranean species and new data on the chaetae of S. papillocercus and S. Major. Cah. Biol. Mar. 2007, 48, 381-390.

251. Di Domenico, M.; Martínez, A.; Worsaae, K. Saccocirridae (Annelida) from the Canary Islands with a description of Saccocirrus slateri sp. nov. Mar. Biodivers. 2019, 49, 2125-2139. [CrossRef]

252. Weigert, A.; Bleidorn, C. Current status of annelid phylogeny. Org. Divers. Evol. 2016, 16, 345-362. [CrossRef]

253. Jouin, C. Status of the knowledge of the systematics and ecology of Archiannelida. Smithson. Contr. Zool. 1971, 76, 47-56.

254. Di Domenico, M.; Martínez, A.; Amaral, A.C.Z.; Lana, P.C.; Worsaae, K. Saccocirridae (Annelida) from the southern and southeastern Brazilian coasts. Mar. Biodivers. 2014, 44, 313-325. [CrossRef]

255. Goodrich, E.S. On the structure and affinities of Saccocirrus. Q. J. Microsc. Sci. 1901, 44, 413-428.

256. Salensky, W. Morphogenetische Studien an Würmern. Mem. Acad. Sci. St. Petersbourg 1907, 19, 1-349.

257. Brown, S.; Rouse, G.; Hutchings, P.; Colgan, D. Assessing the usefulness of histone H3, U2 snRNA and $28 \mathrm{~S}$ rDNA in analyses of polychaete relationships. Aust. J. Zool. 1999, 47, 499-516. [CrossRef]

258. Purschke, G.; Tzetlin, A.B. Dorsolateral ciliary folds in the polychaete foregut: Structure, prevalence and phylogenetic significance. Acta Zool. 1996, 77, 33-49. [CrossRef]

259. Tzetlin, A.B.; Purschke, G. Pharynx and intestine. Hydrobiologia 2005, 535/536, 199-225. [CrossRef]

260. Du Bois-Reymond Marcus, E. On a new archiannelid, Saccocirrus gabriellae, from Brazil. Com. Zool. Mus. 1946, $37,1-11$.

261. Villora-Moreno, S.; Capaccioni-Azzati, R.; Garcia-Carrascosa, A.M. Meiobenthos of sandy beaches from the Gulf of Valencia (Western Mediterranean): Ecology of interstitial polychaetes. Bull. Mar. Sci. 1991, 48, 376-385.

262. Di Domenico, M.; Lana, P.C.; Garraffoni, A.R.S. Distribution patterns of interstitial polychaetes in sandy beaches of southern Brazil. Mar. Ecol. 2009, 30, 47-62. [CrossRef]

263. Gray, J.S.A. A new species of Saccocirrus (Archiannelida) from the West Coast of North America. Pac. Sc. 1969, $23,238-251$.

264. Bobretzky, N.V. Saccocirrus papillocerus, n. gen., n. sp. Tip' novago semeistra annelid. Sravmitel'no-Anatomichskii obcherk. Kiev Odschestva Estest Zap. 1871, 2, 211-259.

265. Pierantoni, U. Observazioni suilo sviluppo embrionale e larvale del Saccocirrus papillocercus Bobr. Mitt. Zool. Stat. Neapel 1906, 18, 46-72.

266. Pierantoni, U. Il genere Saccocirrus Bobretzky e le sue specie. Ann. Ist. Mus. Zool. Univ. Napoli 1907, 2, 1-11.

267. Boaden, P.J.S. The interstitial fauna of some North Wales beaches. J. Mar. Biol. Assoc. UK 1963, 43, 79-96. [CrossRef]

268. Núñez, J.; Brito, M.C.; Docoito, J.R. Anélidos poliquetos de Canarias: Catálogo de especies, distribución y hábitats. Vieraea 2005, 33, 297-321.

269. Bailey-Brock, J.H.; Dreyer, J.; Brock, R.E. Three new species of Saccocirrus (Polychaeta: Saccocirridae) from Hawai'i. Pac. Sc. 2003, 57, 463-478. [CrossRef]

270. Di Domenico, M.; Worsaae, K.; Purschke, G. Saccocirridae Czerniavsky, 1881. In Handbook of Zoology: Annelida; Purschke, G., Böggemann, M., Westheide, W., Eds.; De Gruyter: Berlin, Germany, 2020; Volume 3. 